\title{
NEW TECHNOLOGY AND EMERGING OCCUPATIONS: EVIDENCE FROM ASIA
}

Sameer Khatiwada and Mia Kim Maceda Veloso

NO. 576

April 2019
ADB ECONOMICS WORKING PAPER SERIES 
ADB Economics Working Paper Series

\section{New Technology and Emerging Occupations: Evidence from Asia}

Sameer Khatiwada and Mia Kim Maceda Veloso

No. 576 | April 2019
Sameer Khatiwada (skhatiwada@adb.org) is an economist and Mia Kim Maceda Veloso (miakim.veloso@barcelonagse.eu) is a former consultant at the Economic Research and Regional Cooperation Department (ERCD), Asian Development Bank.

The authors would like to thank John Paul Flaminiano, Rhea Molato Gayares, Pia Marie P. Medrano, and Erik Jan Eleazar for their help with the analysis on new job titles, which was included in the Asian Development Outlook 2018. Many thanks to Yasuyuki Sawada for his detailed comments on an earlier draft; Rana Hasan for his support to this research project; and participants at the ERCD Seminar (November 2018), Asian and Australian Society of Labour Economics Conference in Seoul (December 2018), and the Federation of ASEAN Economic Associations Conference in Manila (November 2018) for their comments and feedback. 
(C) 2019 Asian Development Bank 6 ADB Avenue, Mandaluyong City, 1550 Metro Manila, Philippines

Tel +632632 4444; Fax +6326362444

www.adb.org

Some rights reserved. Published in 2019.

ISSN 2313-6537 (print), 2313-6545 (electronic)

Publication Stock No. WPS190087-2

DOI: http://dx.doi.org/10.22617/WPS190087-2

The views expressed in this publication are those of the authors and do not necessarily reflect the views and policies of the Asian Development Bank (ADB) or its Board of Governors or the governments they represent.

ADB does not guarantee the accuracy of the data included in this publication and accepts no responsibility for any consequence of their use. The mention of specific companies or products of manufacturers does not imply that they are endorsed or recommended by ADB in preference to others of a similar nature that are not mentioned.

By making any designation of or reference to a particular territory or geographic area, or by using the term "country" in this document, $A D B$ does not intend to make any judgments as to the legal or other status of any territory or area.

This work is available under the Creative Commons Attribution 3.0 IGO license (CC BY 3.0 IGO)

https://creativecommons.org/licenses/by/3.o/igo/. By using the content of this publication, you agree to be bound by the terms of this license. For attribution, translations, adaptations, and permissions, please read the provisions and terms of use at https://www.adb.org/terms-use\#openaccess.

This CC license does not apply to non-ADB copyright materials in this publication. If the material is attributed to another source, please contact the copyright owner or publisher of that source for permission to reproduce it. $\mathrm{ADB}$ cannot be held liable for any claims that arise as a result of your use of the material.

Please contact pubsmarketing@adb.org if you have questions or comments with respect to content, or if you wish to obtain copyright permission for your intended use that does not fall within these terms, or for permission to use the ADB logo.

Corrigenda to ADB publications may be found at http://www.adb.org/publications/corrigenda.

Notes:

In this publication, “\$” refers to United States dollars.

ADB recognizes "China" as the People's Republic of China.

The ADB Economics Working Paper Series presents data, information, and/or findings from ongoing research and studies to encourage exchange of ideas and to elicit comment and feedback about development issues in Asia and the Pacific. Since papers in this series are intended for quick and easy dissemination, the content may or may not be fully edited and may later be modified for final publication. 


\section{CONTENTS}

TABLES AND FIGURES

ABSTRACT V v v v v v

$\begin{array}{ll}\text { I. INTRODUCTION } & 1\end{array}$

II. DATA $\quad 4$

A. National Classification of Occupations 4

B. $\quad$ United States Alphabetical Index of Occupations 6

C. Labor Force Surveys 6

III. METHODOLOGY 8

A. Identifying "True" New Job Titles 8

B. Predicting Probability of Access to Emerging Occupations 9

Given Workers' Characteristics

IV. RESULTS

A. $\quad$ New Job Titles and Emerging Occupations in Developing Asia 12

B. Employment Trends in Emerging Occupations: India and Viet Nam 14

C. Adjusted Predictions $\quad 27$

V. CONCLUDING REMARKS

$\begin{array}{ll}\text { APPENDIXES } & 33\end{array}$

$\begin{array}{ll}\text { REFERENCES } & 57\end{array}$ 


\section{TABLES AND FIGURES}

\section{TABLES}

$1 \quad$ National Classification of Occupations: India, Malaysia, the Philippines, and Viet Nam 5

2 Major Occupational Divisions in the National Classification of Occupations 6

3 Summary Statistics, India 1994-2012 7

$4 \quad$ Summary Statistics, Viet Nam 2009-2015

$5 \quad$ Employment in Emerging Occupations, India $\quad 15$

$6 \quad$ Employment in Emerging Occupations, Viet Nam 16

$7 \quad$ Estimates from Logit Model of Occupation Selection, India 2000 and 2012

$8 \quad$ Estimates from Logit Model of Occupation Selection, Viet Nam 2013-2015 25

A2 Variable List $\quad 34$

A3.1 India $2004 \quad 35$

A3.2 India $2005 \quad 36$

A3.3 Malaysia $2008 \quad 40$

A3.4 Philippines $2012 \quad 41$

A3.5 Viet Nam $2008 \quad 42$

A4.1 India 1968-2004 43

A4.2 India 2004-2015 44

A4.3 Malaysia 1998-2008 45

A4.4 Philippines 1990-2012 45

A4.5 Viet Nam 1998-2008 46

A8 Multiple Job Holdings - Estimates from Logit Model of Occupation Selection, India 201251

A9 Stacked Datasets in One Logit Model, India 2000 and 2012

A10 Stacked Datasets in One Logit Model, Viet Nam 2013 and 2015

\section{FIGURES}

1 Share of New Job Titles per Division 12

2 Share of New Job Titles by Skill Level, Selected Countries 13

$3 \quad$ Selected Emerging Occupations with the Highest Proportion of New Job Titles 14

$4 \quad$ Average Monthly Wages of Wageworkers by Division 17

5 Average Monthly Wages of Wageworkers by Sector $\quad 18$

6 Characteristics of Emerging Occupation Cohorts 20

$7 \quad$ Adjusted Predictions, India $\quad 28$

$8 \quad$ Adjusted Predictions, Viet Nam $\quad 30$

A5 Wages of Job Titleholders (Wageworkers) within Emerging Occupations, 47 Viet Nam 2015

A6 Average Monthly Wages of Information and Communication Technology 48 Professional Wageworkers, Viet Nam 2015

A7 Average Monthly Wages of Wageworkers in the Service Sector 49

A8.1 Engagement in Primary and/or Subsidiary Occupations $\quad 50$

A8.2 Employment in Subsidiary Occupations $\quad 50$ 


\begin{abstract}
One of the less well-understood channels through which technology affects labor market outcomes is the creation of new types of work. In this paper, we investigate the emergence of new occupations by comparing various classifications of occupations and predicting probabilities to access them given workers' characteristics. Systematic comparisons of successive lists of National Classification of Occupations in India, Malaysia, the Philippines, and Viet Nam find that most new job titles are primarily information and communication technology- and data-related positions within professional and associate professional occupational divisions. When utilizing microdata of India and Viet Nam, we find that emerging occupations, defined as occupation groups with new job titles, pay higher wages than nonemerging occupations. Further, when using logit models to predict chances of accessing emerging occupations given workers' characteristics, the probability of success is greater for workers who are male, tertiary educated, urbanized, and employed in the service sectors. Adjusted predictions by education and sector show that access to emerging occupations is highest among tertiary-educated workers in services, and that chances of success vary greatly across different age groups.
\end{abstract}

Keywords: industries, innovation, new work, occupations

JEL codes: J21, J23, J24, O14, O33 


\section{INTRODUCTION}

Rapid and radical technological changes, innovation, and increased waves of automation have transformed the world of work, spurring growth in the literature that explores how technology affects jobs (ADB 2018; McKinsey Global Institute 2017; Chang, Rynhart, and Huynh 2016; Frey and Rahbari 2016). For instance, the retail and tech giant, Amazon, which also happens to be one of the largest employers in the United States (US), has been at the forefront of automation, operating at least 100,000 Kiva robots around the world as of 2017. Alibaba, the e-commerce giant, has also recently followed suit by opening the largest robot warehouse in the People's Republic of China to help deal with rising customer demand. Thus, it is no surprise that "displacement effects" of technology, i.e., the effect when machines replace the work of or tasks previously performed by humans, and the increasing automation anxiety that comes along with it, have been at the core of the discussion on how technology affects jobs.

However, technology affects the labor market in more ways than displacement, and one of the relatively less well-understood channels is the potential of technologies to help create "new types of work". "For instance, Acemoglu and Restrepo (2018) refer to the so-called "reinstatement effect" or the effect wherein the creation of new tasks generates new employment opportunities for labor and counterbalances the displacement effect of new technology. For example, while the introduction of cars in the early 1890s has contributed to the displacement (and to an extent, the disappearance) of drivers of horse-drawn carriages, it has also contributed to the emergence of and demand for carrelated occupations, such as car drivers and auto mechanics. The same can be said about computer engineers and web developers upon the mass rollouts of computers in the 1970s and the subsequent introduction of the World Wide Web in the late 1980s. Radical innovations in recent years have also led to considerable increases in cryptocurrency transactions, driving the emergence of and skyrocketing demand for blockchain engineers. Hence, while it is important to study if and/or how workers are being displaced, it is also equally important to investigate if and what new types of work are being created.

To the best of our knowledge, this is one of the few papers that study new types of work by identifying new job titles and analyzing employment patterns in "emerging occupations"-defined as occupation groups in which a (one) new job title is identified-in developing Asia. In doing so, it follows Lin (2011), who compares successive occupation lists to identify new job titles, as well as Schmidt and Strauss (1975) and Eberharter (2012), who predict workers' occupation choice using logit models. ${ }^{2}$ As occupation lists are periodically updated and revised, the changes that they undergo, to an extent, can be indicative of the structural changes and potential effects of new technologies in the labor market that affect different fields of work. ${ }^{3}$ For instance, in Lin's (2011) analysis of new job titles between 1990 and 2000, 840 out of 30,900 (2.7\%) are identified as new occupations. Lin also finds that workers in new occupations are more likely to be in locations that are initially dense in college

We use the term "new types of work" to collectively refer to new job titles and "emerging occupations".

2 Using observable workers' characteristics as explanatory variables, Schmidt and Strauss (1975) predict individuals' selection into one of five occupation groups: professional, white collar, craft, blue collar, and menial. Eberharter (2012) uses a similar approach wherein the dependent variable has categories: (i) academic or scientific professions, managers, professionals, technicians, and associate professionals; (ii) trade and personal services; (iii) agricultural, fishery workers, craft and related workers; (iv) plant and machine operators and assemblers; (v) elementary occupations.

3 The International Standard Classification of Occupations (ISCO) of the International Labour Organization (ILO) are systematically reviewed and revised on a regular basis to account for developments in the labor market, such as the emergence of new occupations (ILO 1993). For example, the proliferation of cable television in India in the 1990s gave rise to an increased demand for cable television installers. 
graduates and industry variety, and that higher-educated workers are more likely to be in "new work"a finding that is consistent with the hypothesis of skill-biased technological change. ${ }^{4}$ Further, he finds that workers in new occupations earn higher wages compared with workers who have similar profiles in preexisting jobs. ${ }^{5}$

Developing Asia presents us with a particularly interesting case in investigating new types of work for three main reasons. First, developing Asia is going through rapid and massive changes in terms of urbanization, digitalization, and social and demographic shifts. A recent report by Manpower Group (2018) has even shown that nations in Asia and the Pacific suffer the most difficulties in filling job vacancies, so learning more about new types of work would help policy makers address talent shortages in their country. ${ }^{6}$ Second, the four countries studied-India, Malaysia, the Philippines, and Viet Nam-are developing countries where poverty remains a key challenge and where research on new types of work is scarce. Last, a closer look into India and Viet Nam would allow us to compare the new types of work in a large country where the service sector has been a key driver of growth, with those in a small country where the manufacturing sector has played a large role. In light of these, we hope to shed light on two main questions. First, what new types of work can we identify in these countries? Second, how and to what extent do workers' characteristics affect chances of accessing emerging occupations?

Several factors may influence an individual's probability to access emerging occupations. Perhaps one of the most significant factors is one's sector of employment as some sectors undergo rapid and radical innovations, while others do so by smaller and incremental changes. As such, new types of work oftentimes emerge in the so-called "high-tech" industries-often more prominent in urbanized areas ${ }^{7}$-with high concentrations of science, technology, engineering, and mathematics (STEM) workers. ${ }^{8}$ Indeed, STEM occupations are becoming progressively more in-demand in the increasingly digitalized world, which constantly requires information and communication technology (ICT) specialist skills to further drive innovation and support already existing digital infrastructures. ${ }^{9}$ Not surprisingly, workers with high educational attainments typically hold these types of occupations, which brings us to our next point: human capital.

Human capital is a significant factor when it comes to accessing new types of work because it ultimately affects one's capacity and qualification to perform certain tasks. This factor is particularly vital, considering that technology (e.g., computers) has been documented to be skill biased, i.e., favoring digitally literate, highly skilled, and educated workers over unskilled labor (Autor, Katz, and Krueger 1997; Lee and Wie 2013), which induces a rise in the skill premium-the ratio of skilled to unskilled wages. Aside from the skill-biased nature of technologies, recent research also points to its

4 Lin uses the term, "new work" (borrowed from Jacobs 1969) to refer to jobs requiring new combinations of activities.

5 Lin (2011) finds that the estimated wage premium of new work is positive, large, and significant in 1990 and 2000, upward of $30 \%$ (logarithmic) over observationally similar workers who are not in new work.

6 Skill shortages are reported to be at a 12-year high with a global average of $45 \%$ of employers surveyed reporting difficulties filling job vacancies. For instance, among the employers surveyed in India, $56 \%$ report to have difficulties filling job vacancies, of which the toughest are those within finance and information technology (IT), due to lack of skilled applicants (Manpower Group 2018).

7 Lin (2011) also finds that more urbanized workers are more likely to be found in new work. More specifically, in 2000, greater Washington, the San Francisco Bay area, and Austin had the highest new work shares.

8 Different institutions have different definitions of "high-tech" industries. For example, the U.S. Bureau of Labor Statistics defines "high-tech" industries as those with two and a half times the national average percent of jobs in STEM occupations (U.S. Bureau of Labor Statistics 2016).

9 Interestingly, in 2012, 29.2\% of about 5 million students who received undergraduate degrees in STEM subjects worldwide were from India, followed by the People's Republic of China with 26\% (UNCTAD 2018). 
task-biased nature (e.g., computers, robots, automation) as responsible to the recent trend of polarization in the labor market, i.e., the rise of employment shares in both high-wage and low-wage jobs (Goos and Manning 2007).

Findings on the relationship between gender and technology are somewhat mixed, although recent research also links findings to the importance of human capital. Kiyota and Maruyama (2018), for instance, find that ICT capital stock has significant positive effects on the demand for high-skilled female workers. Similarly, Chun and Tang (2018) find that Vietnamese firms' investments in ICT particularly increased relative demand for high-skilled female workers, but they also find that the effect of ICT is weaker in more complex and innovative industries, which the authors attribute to gender differences in education. Indeed, labor market gaps in the outcomes of men and women may also be due to fewer investments in human capital (Polachek and Siebert 1993) or labor market failures such as discrimination (Murciano-Goroff 2018). This may be especially worth noting in Asia, where there is historically strong cultural and economic preferences for sons. ${ }^{10}$

Age is another essential variable when it comes to studying technology adaptation and worker employability. As in the previous point, most findings on age and technology also revolve around skills, particularly on skills obsolescence and adaptability problems of older workers in the labor market when it comes to the use of ICTs (Borghans and ter Weel 2002; Aubert, Caroli, and Roger 2006; Beckmann and Schauenberg 2007; Schleife 2008). For instance, Peng, Anwar, and Kang (2017) find that demand for older workers decreased in the 1970s and 1980s - the period of the home computer boom-due to the impact of ICT and due to skill bias. On the other hand, Acemoglu and Restrepo (2017) explore the reverse side of the relationship, documenting that aging leads to greater technological development and adoption. They show that robots substitute for middle-aged workers (aged between 36 and 55), and that an aging workforce is associated with pronounced increases in the adoption of automation technologies across countries."

The analyses of successive occupation lists in India, Malaysia, the Philippines, and Viet Nam find that most new job titles are primarily ICT and data-related positions within the professional and associate professional occupational divisions. The microdata of India and Viet Nam over the 19942012 and 2009-2015 periods, respectively, further show evidence that emerging occupations pay relatively higher wages than nonemerging occupations. We also find that despite this, very few workers-only 4\% of workers in India 2012 and as low as 2\% in Viet Nam 2015-are in emerging occupations. Further, when using logit models to predict the chances of accessing emerging occupations given workers' characteristics, the probability of success is greater for workers who are male, tertiary educated, urbanized, and employed in the service sectors (relative to their base categories). Adjusted predictions by sector, education, and age group also show that the chances of success vary widely across age groups, suggesting that older workers, especially those who are tertiary educated in the service sectors, may not necessarily need to worry about the displacement effects of

10 Economic arguments for son bias revolve around the idea that sons are expected to support households financially throughout their lives (Jayaraman, Mishra, and Arnold 2009; Wang 2005) and, as such, relatively more resources are poured into their education. Daughters, on the other hand, are perceived as economic liabilities in societies that practice dowry payments (Gupta and Dubey 2006). Anukriti, Bhalotra, and Tam (2016) find that, in India, parents' annual medical and educational expenditure on first-born girls are lower than those spent on first-born boys.

11 Interestingly and in relation to the aforementioned variables of interest, the importance of age and gender seems especially evident in the IT sector as seen among many of the world's top tech companies, which have been criticized to be "overwhelmingly young and male" (Quartz 2017). For instance, the median age of workers in tech giants such as Facebook, Google, and Apple ranges between 29 and 31, whereas the shares of female workers go as low as 14\% in SpaceX and approximately 25\%-30\% in IBM, Amazon, and Microsoft (Payscale 2018). These estimates are much lower than the median age in the US workforce, being 42 years old (U.S. Bureau of Labor Statistics 2017). 
technology. Nevertheless, results suggest that government policy should ensure that appropriate mechanisms are in place to increase employment in emerging occupations and new types of work in general, and to help vulnerable or less-skilled workers gain better access to them.

An important contribution of this paper is that it identifies new types of work in developing Asia, and investigates how and to what extent workers' characteristics can influence access to emerging occupations. Another key contribution is that, not only does it highlight the importance of intersectoral reallocations of labor from agriculture to nonagriculture sectors, it also stresses the importance of knowing which types of occupation groups within these nonagriculture sectors are those that have the potential to yield higher returns to transitioning workers. As such, research findings of this paper have important policy implications for developing Asia as a whole, especially in light of the Fourth Industrial Revolution and the positive and negative disruptions it brings in the world of work. The rest of the paper is organized follows. Sections II and III describe the data and methodology, respectively. Section IV presents the results and section $V$ concludes.

\section{DATA}

This paper makes use of three types of data: the first is the National Classification of Occupations (NCOs) of India, Malaysia, the Philippines, and Viet Nam, the second is the US Alphabetical Index of Occupations, and last, the Labor Force Surveys (LFSs) containing the individual-level data of workers in India and Viet Nam.

\section{A. National Classification of Occupations}

A country's NCO is a comprehensive repository that describes and assigns codes to various occupations, often grouped according to combinations of specific tasks and work functions-in that country. NCOs are used in all types of censuses and sample surveys; and data collection, processing, and analysis of survey results, in addition to their applications in policy formulation and policy analysis. These are revised and updated occasionally to align with the ILO's International Standard Classification of Occupations (ISCO) and account for developments in the labor markets, including the emergence of new occupations (ILO 1993).

The first empirical exercise of this paper compares the NCOs of India, Malaysia, the Philippines, and Viet Nam. ${ }^{2}$ We use three successive lists in India and compare 1968 NCO with 2004 and 2004 NCO with 2015. We compare two lists for the rest of the countries: 1998 Malaysian Standard Classification of Occupations with 2008 in the case of Malaysia, 1998 Viet Nam Standard Classification of Occupations with 2008 in the case of Viet Nam, and the 1990 Philippine Standard Classification of Occupations with 2012 in the case of the Philippines. Table 1 summarizes the basic information about the occupation lists used from each country, including the number of divisions, occupation groups, and job titles found in each NCO.

12 Countries use different terminologies when referring to the occupation codes in their NCOs. Therefore, for consistency, this paper refers to the 1-digit level of disaggregation in NCOs as divisions, 3-digit codes as occupation groups, while the most disaggregated level of the occupation codes, which differs from country to country, refers to job titles. Division 10, which often refers to armed forces occupations or workers not elsewhere classified, is not included in this analysis. 
Table 1: National Classification of Occupations: India, Malaysia, the Philippines, and Viet Nam

\begin{tabular}{|c|c|c|c|c|c|c|c|c|c|}
\hline \multirow[b]{2}{*}{$\begin{array}{l}\text { National Classification of } \\
\text { Occupations }\end{array}$} & \multicolumn{3}{|c|}{ India } & \multicolumn{2}{|c|}{ Malaysia } & \multicolumn{2}{|c|}{ Philippines } & \multicolumn{2}{|c|}{ Viet Nam } \\
\hline & 1,968 & 2,004 & 2,015 & 1,998 & 2,008 & 1,990 & 2,012 & 1,998 & 2,008 \\
\hline $\begin{array}{l}\text { International Standard } \\
\text { Classification of Occupations } \\
\text { alignment }\end{array}$ & 1,968 & 1,988 & 2,008 & 1,988 & 2,008 & 1,988 & 2,008 & 1,988 & 2,008 \\
\hline Number of divisions (1 digit) & 8 & 10 & 9 & 9 & 10 & 9 & 9 & 10 & 10 \\
\hline $\begin{array}{l}\text { Number of occupation groups } \\
\text { (3 digit) }\end{array}$ & 462 & 116 & 127 & 117 & 143 & 134 & 133 & 131 & 191 \\
\hline \multirow[t]{2}{*}{ Number of job titles } & 2,484 & 2,945 & 3,600 & 1,426 & 2,338 & 422 & 498 & 460 & 506 \\
\hline & (5-digit) & (6-digit) & (8-digit) & (5-digit) & (5-digit) & (4-digit) & (4-digit) & (4-digit) & (4-digit) \\
\hline
\end{tabular}

Notes: Levels of disaggregation of job title codes are in parentheses. Official total number of job titles in Malaysia reported in Malaysian Standard Classification of Occupations 2008 is greater, but is not unique. Numbers reported above also exclude the armed forces and those labeled as "JPA" (Malay: Jabatan Perkhidmatan Awam) or Public Service Department in the case of Malaysia.

Sources: Various National Classification of Occupations of the different countries, and authors' own calculations whenever total counts were not mentioned.

One important facet of NCOs, as in the ISCO, are the skill levels that are assigned to every division. Ranging from 1 to 4, a skill level is defined by the ILO (2012, pp. 11-14) as a "function of the complexity and range of tasks and duties to be performed in an occupation". It is measured by the nature of work, the level of formal education, and the amount of training or work experience required to competently perform the tasks and duties involved..$^{13} \mathrm{~A}$ similar classification of skill levels by division is constructed by Autor (2014): divisions 1, 2, and 3 are categorized as "high-skilled"; divisions 4, 7, and 8 are "middle-skilled" occupations; whereas divisions 5 and 9 are classified as "low-skilled" occupations. ${ }^{14}$ Due to the ambiguity of the skill level associated with division 1 , we mainly refer to Autor's skill level classification in the later stages of the paper. ${ }^{15}$ Table 2 shows the occupation divisions (1-digit) and the skill levels assigned to each of them by the ILO and Autor.

13 Divisions (and thus the occupations falling under them) assigned at skill level 4, the highest skill level, typically involve complex problem solving, research, managing, and decision making, and the knowledge and skills required to perform these tasks are usually gained at higher education institutions. Appropriate formal qualifications are also often essential requirements for entry into these occupations. Occupations assigned skill level 3, like those assigned skill level 4, also generally require high levels of literacy and numeracy, although extensive relevant work experience may sometimes substitute formal education. On the other hand, skill level 2 is assigned to occupations that often involve operating machineries and other forms of manual dexterity. Skill level 1 mainly involves physical and manual tasks requiring physical strength or endurance.

14 Division 6 was not assigned a particular skill level in Autor (2014), but we have decided to categorize division 6 as low skilled as agriculture and fishery work are arguably more manual-work intensive, requiring physical strength and/or endurance as opposed to high literacy or numeracy skills.

15 Various NCOs often do not assign a specific skill level to division 1. For instance, in India 2004 and 2015 NCO, it has been argued that the skills required to execute the tasks and duties of the division 1 occupations "varied to such an extent that it was not feasible to link them with any of the four broad skill levels" (NCO 2015, p. 12). 
Table 2: Major Occupational Divisions in the National Classification of Occupations

\begin{tabular}{llcc}
\hline Division Code & \multicolumn{1}{c}{ Division Title } & ISCO Skill Level & Autor Skill Level \\
\hline 1 & Legislators, senior officials, and managers & $3+4$ & HS \\
2 & Professionals & 4 & HS \\
3 & Technicians and associate professionals & 3 & HS \\
4 & Clerks & 2 & MS \\
5 & Service workers and shop and market sales professionals & 2 & LS \\
6 & Skilled agricultural and fishery workers & 2 & LS \\
7 & Craft and related trades workers & 2 & MS \\
8 & Plant and machine operators and assemblers & 2 & MS \\
9 & Elementary occupations & 1 & LS \\
\hline
\end{tabular}

$\mathrm{HS}=$ high skilled, ISCO = International Standard Classification of Occupations, LS = low skilled, MS = middle skilled.

Sources: National Classification of Occupations of India, Malaysia, the Philippines, and Viet Nam; and International Labour Organization's ISCO.

\section{B. United States Alphabetical Index of Occupations}

The US Alphabetical Index of Occupations is used as a second filter, and thereby a robustness check when identifying new job titles. The US Alphabetical Index of Occupations are compiled by the U.S. Census Bureau to classify occupations from the censuses and surveys conducted by the Population Division of the U.S. Census Bureau (U.S. Census Bureau 1950). The index lists occupation titles as they appear on the Census and survey schedules, with a code indicating the corresponding occupation category in which each title is to be classified; each code describes a person's occupation, defined as "the kind of work the person was doing" (U.S. Census Bureau 1950). The index provides job titles down to the smallest unit, which means that a large number of job titles are included. To illustrate, the number of titles listed in the 1950-2000 indexes range from 25,000 to 31,000 (Lin 2011).

\section{Labor Force Surveys}

Six LFSs are used in the second part of the empirical exercise. Each full sample is ultimately divided into two cohorts-emerging occupation workers and nonemerging occupation workers.

The employment and unemployment surveys of the National Sample Survey (NSS) carried out by the National Sample Survey Office (NSSO) are the primary sources of data on various labor indicators at the national and state levels in India. This study uses the 50th, 55th, and 68th rounds of the NSSs which were conducted from July 1993 to 1994, from July 1999 to 2000, and from July 2011 to June 2012, respectively. The NSSO surveys typically cover the entire country of India with the exception of certain interior areas such as Nagaland and the Andaman and Nicobar Islands. However, in the 50th round, only three districts out of the 12 could be surveyed (NSSO 1996). The survey uses interviews for data collection from a sample of randomly selected households and members of the household. The 55th and 68th rounds of surveys, the bases for the 2000 and 2012 India LFSs, cover the whole of India except (i) interior villages of Nagaland situated beyond 5 kilometers of the bus route; and (ii) villages in Andaman and Nicobar Islands, which remained inaccessible throughout the year. In 2000, 165,244 households were surveyed, of which 97,986 were in rural areas and 67,258 were in urban areas. The number of persons surveyed was 509,779 in rural areas and 309,234 in urban areas (NSSO 2000). In 2012, among the 100,957 households surveyed, 59,129 were in rural areas, while 41,828 were in urban areas. The number of persons surveyed was 459,784, among which 281,327 were in rural areas, while 178,457 were in urban areas (NSSO 2014). Table 3 gives an overview of the main characteristics of the full sample, and the differences between the two cohorts studied of each LFS year in India. 
Table 3: Summary Statistics, India 1994-2012

Number of observations and mean of variables (employed $>=15$ and $<=65$ years)

\begin{tabular}{|c|c|c|c|c|c|c|c|c|c|}
\hline \multirow[b]{2}{*}{$\mathrm{N}$} & \multicolumn{3}{|c|}{1994} & \multicolumn{3}{|c|}{2000} & \multicolumn{3}{|c|}{2012} \\
\hline & $\begin{array}{c}\text { Full } \\
192,829\end{array}$ & $\begin{array}{c}\text { N_Em_Occ } \\
188,427\end{array}$ & $\begin{array}{c}E m \_O c c \\
4,402\end{array}$ & $\begin{array}{c}\text { Full } \\
275,966\end{array}$ & $\begin{array}{c}\text { N_Em_Occ } \\
267,746\end{array}$ & $\begin{array}{c}E m \_O c c \\
8,220\end{array}$ & $\begin{array}{c}\text { Full } \\
153,387\end{array}$ & $\begin{array}{c}\text { N_Em_Occ } \\
145,806\end{array}$ & $\begin{array}{c}E m \_O c c \\
7,581\end{array}$ \\
\hline Sector & 1.767 & 1.744 & 2.791 & 1.826 & 1.798 & 2.745 & 2.155 & 2.125 & 2.739 \\
\hline Education & 2.149 & 2.105 & 4.024 & 2.298 & 2.248 & 3.931 & 2.822 & 2.752 & 4.158 \\
\hline Age group & 2.667 & 2.663 & 2.830 & 2.686 & 2.681 & 2.853 & 2.891 & 2.886 & 2.982 \\
\hline Sex & 0.758 & 0.755 & 0.891 & 0.758 & 0.753 & 0.889 & 0.783 & 0.782 & 0.815 \\
\hline Location & 0.342 & 0.333 & 0.752 & 0.351 & 0.339 & 0.729 & 0.372 & 0.359 & 0.638 \\
\hline Work experience & 24.971 & 25.094 & 19.701 & 24.638 & 24.772 & 20.263 & 24.808 & 25.030 & 20.535 \\
\hline Marital status & 1.866 & 1.867 & 1.818 & 1.856 & 1.857 & 1.826 & 1.879 & 1.879 & 1.865 \\
\hline
\end{tabular}

Em_Occ $=$ emerging occupations, N_Em_Occ = not emerging occupations.

Source: Authors' calculations.

The LFSs in Viet Nam, carried out by the General Statistics Office (GSO), collect information on the labor market participation of persons aged 15 and above residing in Viet Nam. The GSO compiles national indicators on labor, employment, unemployment, and income. Data from the LFSs are representative at the national level, urban or rural, six socioeconomic zones, as well as two main cities: Ha Noi and Ho Chi Minh City (GSO 2009). Households are considered the sample units, and all eligible individuals in sampled households comprise the sample for the survey. The sample size of about 18,000 households provides reliable estimates for each of the 16 domains. Similarly, in the 2013 and 2015 surveys, data coverage includes the whole country, covering all 63 centrally governed provinces, and the target population includes individuals aged 15 years and above in urban and rural areas (GSO 2013, 2015). Table 4 gives an overview of the main characteristics of the full sample and the differences between the two cohorts studied of each LFS year in Viet Nam.

Table 4: Summary Statistics, Viet Nam 2009-2015

Number of observations and mean of variables (employed $>=15$ and $\langle=65$ years)

\begin{tabular}{lccccccccc}
\hline & \multicolumn{3}{c}{2009} & \multicolumn{3}{c}{2013} & \multicolumn{2}{c}{2015} \\
\cline { 2 - 10 } $\mathrm{N}$ & Full & N_Em_Occ & Em_Occ & Full & N_Em_Occ & Em_Occ & Full & N_Em_Occ & Em_Occ \\
\hline Sector & 32,176 & 31,445 & 731 & 366,080 & 359,897 & 6,183 & 445,828 & 437,466 & 8,362 \\
Education & 2.056 & 2.037 & 2.862 & 1.896 & 1.880 & 2.845 & 1.946 & 1.929 & 2.846 \\
Age group & 1.563 & 1.535 & 2.762 & 2.628 & 2.615 & 3.434 & 2.649 & 2.634 & 3.412 \\
Sex & 2.739 & 2.748 & 2.364 & 2.854 & 2.859 & 2.570 & 2.932 & 2.941 & 2.481 \\
Location & 0.500 & 0.498 & 0.603 & 0.517 & 0.515 & 0.628 & 0.516 & 0.514 & 0.629 \\
Work & 0.530 & 0.524 & 0.817 & 0.455 & 0.450 & 0.769 & 0.404 & 0.398 & 0.727 \\
experience & 27.787 & 28.023 & 17.658 & 26.173 & 26.327 & 17.222 & 24.071 & 24.237 & 15.411 \\
Marital status & 1.851 & 1.854 & 1.717 & 1.875 & 1.877 & 1.774 & 1.889 & 1.891 & 1.758 \\
\hline
\end{tabular}

Em_Occ = emerging occupations, N_Em_Occ = not emerging occupations.

Source: Authors' calculations. 


\section{METHODOLOGY}

The methodology of this paper consists of two main parts: (i) identifying new job titles using successive NCO lists and the US Alphabetical Index of Occupations and (ii) predicting the chances of workers to access emerging occupations given observable workers' characteristics using logit models.

\section{A. Identifying "True" New Job Titles}

A two-step process is followed when identifying new job titles. ${ }^{16}$ We first identify potentially new job titles using two successive waves of NCOs, and subsequently identify true new job titles by filtering out the old or preexisting titles using the US Alphabetical Index of Occupations.

To identify potentially new job titles, all the job titles listed in two successive NCOs are compared. ${ }^{17}$ For instance, we identify new job titles in 2004 NCO by comparing 1968 and 2004 NCOs, and we compare 2004 and 2015 NCOs to identify new job titles in 2015 NCO in the case of India. The basic idea is that, if a job title in the more recent list of the two classifications does not exist in the previous one, then the said job title is potentially new. ${ }^{18}$ We do this exercise while controlling for any form of relabeling or reclassification; newly added job titles specifically defined as "others" or "job title $\mathrm{x}$-not elsewhere classified," but are included in the more recent version of the NCO list, are not considered new. ${ }^{19}$

The next step, which serves as a robustness check to our preliminary findings, entails comparing the potentially new job titles with the job titles listed in the US Index of Occupations due to the index's well-known exhaustiveness of job listings. The assumption is that the US Index of Occupations is a proxy for an extension of the job titles listed in the older NCO used in the exercise. The version of the US index used is older than the version of the previous NCO used to account for a "lag" in the emergence of new job titles given the different stages of development in the countries studied and the US. For instance, we cross-check the potentially new job titles identified in the comparison of India's 1968 and 2004 NCOs against the job titles listed in the 1950 US Index of Occupations. In this part of the exercise, we inherently assume that the 1950 US Index of Occupations is a form of an extension of the 1968 India NCO. The idea at this stage of the exercise is thus: If the potentially new job title identified in India's 2004 NCO also does not exist in the 1950 US Index of Occupations, then it is considered truly new. We conduct this exercise for India, ${ }^{20}$ Malaysia, the

16 Only the main occupations of workers are observed, but we conduct a brief exercise taking into account subsidiary occupations as well as a robustness check in the case of India 2012 (Appendix 8).

17 In some cases, an official concordance of the two NCOs are available online in the official websites of the government statistics offices of the countries studied. It is also important to check which ILO ISCO versions the NCO editions are patterned after for two reasons. First, one can identify which technological advances were made during the time studied. Second, and as a consequence of the first point, one gains insight about what types of new job titles may emerge. The ISCO pattern of a certain NCO can usually be determined by looking at the 2-digit occupation groups in an NCO. Some $\mathrm{NCOs}$ may have certain diversions from the ISCO lists that they are supposedly patterned after by including additional occupation groups (as in the case of Viet Nam Standard Classification of Occupations).

18 For example, if job title $x$ exists in India 2004 NCO but not in 1968 NCO, then we consider job title $x$ as potentially new.

19 Other indicators of new jobs are also used. In some cases, job titles specifying a type of technology not widely used in the previous NCO are considered new. This involves investigating when the technology may have penetrated the market. For example, managerial positions are generally categorized as old job titles unless the specification entails a new type of technology.

20 The 1994 LFS of India follows 1968 NCO as its occupation classification. However, we use an official concordance (1968 and 2004 NCOs) to see which occupation groups in 1968 NCO are emerging occupations. In doing so, we exclude occupation groups that have more than one corresponding 2004 NCO 3-digit match. Thus, estimates of emerging occupation workers in the 1994 LFS of India may be underestimated. 
Philippines, and Viet Nam using the 1950 and 1970 US Indexes of Occupations. ${ }^{21}$ A critical aspect of this part of the exercise is that we can now isolate emerging occupations, occupation groups in which a (one) new job title has been identified by moving the level of analysis of occupation codes from the most disaggregated level (job titles) to codes at the 3-digit level (occupation groups). ${ }^{22}$

Indeed, a higher level of disaggregation of occupation codes is generally more sensitive to the categorization of emerging occupation groups, but we employ occupation analysis at the 3-digit level largely due to data constraints, and since it is arguably more feasible and pragmatic to make policy changes targeting broad occupation groups rather than specific job titles. ${ }^{23}$ Other limitations of the identification process include potential measurement errors from comparing occupation lists manually and the subjective judgment of whether a technology was widely used in the year of the previous NCO. It could also be argued that using the US Index of Occupations as a proxy for an extension of a country's occupation list is problematic because of the differences between the countries studied and the US. Another potential concern could be that one single job title categorized as new is a low threshold for an occupation group to be considered an emerging occupation. Despite these limitations, we argue that the exercises nevertheless provide an insight into the new types of work in developing Asia. ${ }^{24}$ We expect many new job titles to be related to computers or other prominent types of technologies during the time period studied so most new job titles could be ICT- and data-related positions.

\section{B. Predicting Probability of Access to Emerging Occupations Given Workers' Characteristics}

To investigate workers' chances of accessing emerging occupations given observable characteristics, view $y_{i}$ as a realization of the binary dependent variably $Y_{i}$ that takes a value of 1 if the $i$-th individual is employed in an emerging occupation and 0 otherwise, with probability of "success" $P\left(y_{i}=1\right)$ and "failure" $1-P\left(y_{i}=0\right)$. Let $\mathbf{x}_{i}$ be a vector of covariates and $\boldsymbol{\beta}$ be the coefficients.

The probability of success in a logistic model with a binary process is

$$
p_{i}\left(y_{i}=1\right)=\frac{\exp \left\{\mathbf{x}_{i}^{\prime} \boldsymbol{\beta}\right\}}{1+\exp \left\{\mathbf{x}_{i}^{\prime} \boldsymbol{\beta}\right\}},
$$

and the probability of failure is

$$
1-p_{i}\left(y_{i}=0\right)=\frac{1}{1+\exp \left\{\mathbf{x}_{i}^{\prime} \boldsymbol{\beta}\right\}}
$$

${ }^{21}$ NCOs patterned after the 1988 and 1968 ISCO are cross-checked with the 1970 and 1950 US Index of Occupations, respectively.

22 Lin (2011) also observes 3-digit occupation codes as this is the level of disaggregation that is available in the US microdata.

23 Occupation codes in LFSs are often set at the 2-digit or 3-digit level. Hence, possibilities of observing employment trends in new job titles, as opposed to occupation groups, are limited.

24 For example, $2012 \mathrm{NCO}$ was introduced to update job roles linked to the IT sector and to reorganize job roles of service sector workers (India 2015 NCO). 
The odds, given by the ratio of success and failure, are expressed as

$$
\operatorname{odds}_{i}=\frac{p_{i}\left(y_{i}=1\right)}{1-p_{i}\left(y_{i}=0\right)}=\exp \left\{\mathbf{x}_{i}^{\prime} \boldsymbol{\beta}\right\}
$$

Taking the natural logarithm of the odds gives us the logistic regression of $y_{i}$ on $\mathbf{x}_{i}$, which estimates parameter values for $\boldsymbol{\beta}$ through maximum likelihood estimation (Appendix 1 ) such that

$$
\ln \left(\frac{P\left(y_{i}=1\right)}{1-P\left(y_{i}=0\right)}\right)=\mathbf{x}_{i}^{\prime} \boldsymbol{\beta}
$$

The odds ratios (ORs), which are the exponentiated coefficients or the ratio by which the odds change for every unit increase in the independent variable, are given by

$$
O R=\frac{p_{1}}{1-p_{1}} / \frac{p_{2}}{1-p_{2}},
$$

where $p_{1}$ and $p_{2}$ refer to the probability of success in groups 1 and 2 , respectively.

As in Long and Freese (2006), we make results more tangible by presenting adjusted predictions (also known as predictive margins or predicted probabilities), specifically marginal effects at representative values, wherein we choose values for one or more $x$ variables of interest and see how predicted probabilities differ. ${ }^{25}$ All explanatory variables used are categorical and include the worker's educational attainment, sector, age group, location (urban or rural), gender, and marital status. ${ }^{26}$ As we expect most emerging occupations to be generally ICT-related, based on the existing literature, we anticipate workers who are male, urban based with tertiary educational attainments and working in the service sector to have greater chances and/or predicted probabilities of accessing emerging occupations on average (relative to base categories). Findings on age groups will be particularly interesting as younger workers may be more tech savvy (Olson et al. 2011), but older workers will likely have an advantage in terms of work experience. ${ }^{27}$

One potential concern worth addressing relates to the logistic regression's characteristic of noncollapsability, since this analysis ultimately entails comparisons of effects across groups. ${ }^{28}$ Indeed, some researchers have suggested that it is problematic to compare coefficients and odds ratios across groups, models, and years-even when using the same independent variables due to potential differences in the predictions of effects of the models and unobserved heterogeneity (Allison 1999,

25 We use Stata's margins command to calculate predictive-adjusted predictions (also known as margins) from the logit models. With adjusted predictions, we specify values for each of the independent variables in the model and compute the probability of success for individuals who have said values.

26 We control for region and potential years of work experience, which might affect the chances of workers to access emerging occupations. Potential years of work experience is calculated as: pot. work exp. = age - years of schooling -6 , where 6 is assumed to be the age of entry to school. See Appendix 2 for the variable list and categories.

27 The types of profiles or combinations of $x$ values that would offer the greatest probabilities of access to emerging occupations would ultimately depend on the types of emerging occupations identified. For instance, emerging occupations belonging to professional and associate professional divisions would likely require formal education and training, and thus perhaps older, tertiary-educated, and urban-based workers in the manufacturing or service sectors will likely have greater probabilities of access.

28 Noncollapsability is when including an additional explanatory variable to the model likely changes the effects of the other explanatory variables, even if there is no correlation between them. 
Long 2009, Mood 2010). However, Buis (2017) and Kuha and Mills (2017) argue that problems of comparisons primarily arise when the dependent variable of interest in the logistic regression is interpreted as some unobserved latent propensity $y^{*}$; i.e., the unit is unknown or one has a (rational choice) theory exploring individual choice and utility maximization, which is not the case in this study. ${ }^{29}$ Instead, we follow Buis (2017), and interpret the dependent variable $y$ in this analysis as a "chance" or a "degree of plausibility" (Jaynes 2003), i.e., an assessment of how likely it is that an event occurs necessarily conditional on the information available, as represented by the independent variables in the model. This interpretation allows us to have a known scale of the dependent variable, i.e., the logarithm of the odds or the logarithm of the expected number of "success" per "failure," whose scale does not change when we add or remove variables from the model.

Thus, the intuition is the following: We are already certain about the outcomes of the persons in the datasets because we know whether, in fact, they have selected into emerging occupations. We simply use the logistic regression to model the likelihood that hypothetical workers with the same observable characteristics as the workers in the datasets, but for whom the outcomes are unknown, do end up selecting into emerging occupations. Interpreted this way, the chance is defined by and is conditional on what we know about the workers and not an absolute property of the workers in the datasets themselves (Keynes 1921 [2004]), nor is it something that exists outside of the model. All persons with the same characteristics share the same chance, such that the logistic regression model interpreted in terms of chance is a "population averaged model" (Buis 2017; Agresti 2013; Fitzmaurice, Laird, and Ware 2004). Interpreting the dependent variable this way permits us to use odds ratios as meaningful effect-sizes and allows us to compare differences in effects. ${ }^{30}$ Interestingly, Buis (2017) also notes that interpreting $y$ this way particularly makes sense for studies of "inequality of opportunity" that seek to quantify how likely it is that someone with a certain type of background attains a "desirable position" in society, which is being employed in emerging occupations in this case.

Another potential concern is that the positive outcome in the study, $y=1$, may be considered a "rare event" in that the incidences of positive outcomes are heavily outnumbered by those of negative outcomes, $y=0$. As seen in Table 4, only approximately $2 \%-4 \%$ of all outcomes in India and only approximately $1 \%-2 \%$ in Viet Nam are positive. Maximum likelihood estimates (MLEs) of the logistic model are well-known to suffer from small sample bias, that the MLEs have substantial bias away from zero (Leitgöb 2013, Long 1997) and that this degree of bias is strongly dependent on the number of cases in the less frequent of the two categories. However, the datasets do not suffer from very small sample sizes nor do we encounter issues of quasi-complete or complete separation (perfect prediction)-a condition in which MLEs tend to infinity. ${ }^{31}$ Further, Allison (2012) argues that the rarity of the events themselves is not the specific problem when dealing with rare events in a logistic regression, but rather the possibility of a small number of cases on the rarer of the two outcomes. ${ }^{32}$ Therefore, we maintain that a conventional logistic regression remains an appropriate method for this study.

29 Interpreting the dependent variable as latent, $y^{*}$, means that the unit is unknown, and adding a variable to the regression reduces the residual variance, thus changing the scale of the latent dependent variable and making it problematic to compare effects across models and groups.

30 Other efforts to circumvent this issue include using standardized regression coefficients (Karlson 2015, Winship and Mare 1984) and directly estimating the degree of heterogeneity and controlling for it (Allison 1999, Williams 2009).

31 In such a case, a firthlogit or a penalized maximum likelihood estimation, as proposed by Firth (1993), would have been a more appropriate approach (Allison 2012, Williams 2018).

32 Allison (2012) notes that a sample size of 1,000 with only 20 events is problematic, but a sample size of 100,000 cases with 2,000 events is "golden." Similarly, Long (1997, p. 54) offers a rough estimate regarding sample sizes, and states that it is risky to use maximum likelihood estimations on samples smaller than 100 while samples larger than 500 are adequate. 


\section{RESULTS}

\section{A. New Job Titles and Emerging Occupations in Developing Asia}

The analyses of various NCO lists find the emergence of 54 new job titles out of 2,945 (1.8\%) in India 1968-2004; 114 out of 3,600 (3.2\%) in India 2004-2015; 26 out of 2,338 (1.1\%) in Malaysia; 18 out of 498 (3.6\%) in the Philippines; and 16 out 506 (3.2\%) in Viet Nam. ${ }^{33}$ Figure 1 shows that most new job titles primarily appear in the professionals and technicians and associate professionals divisions. ${ }^{34}$ India (1968-2004) has combined division shares of $94 \%$, followed by Viet Nam at $82 \%$, Malaysia at $80 \%$, India (2004-2015) at 62\%, and the Philippines at 45\%. Recall that the ILO (2012) and Autor (2014) regard the occupations in these two divisions as high skilled due to the complexity of the knowledge required and tasks involved.

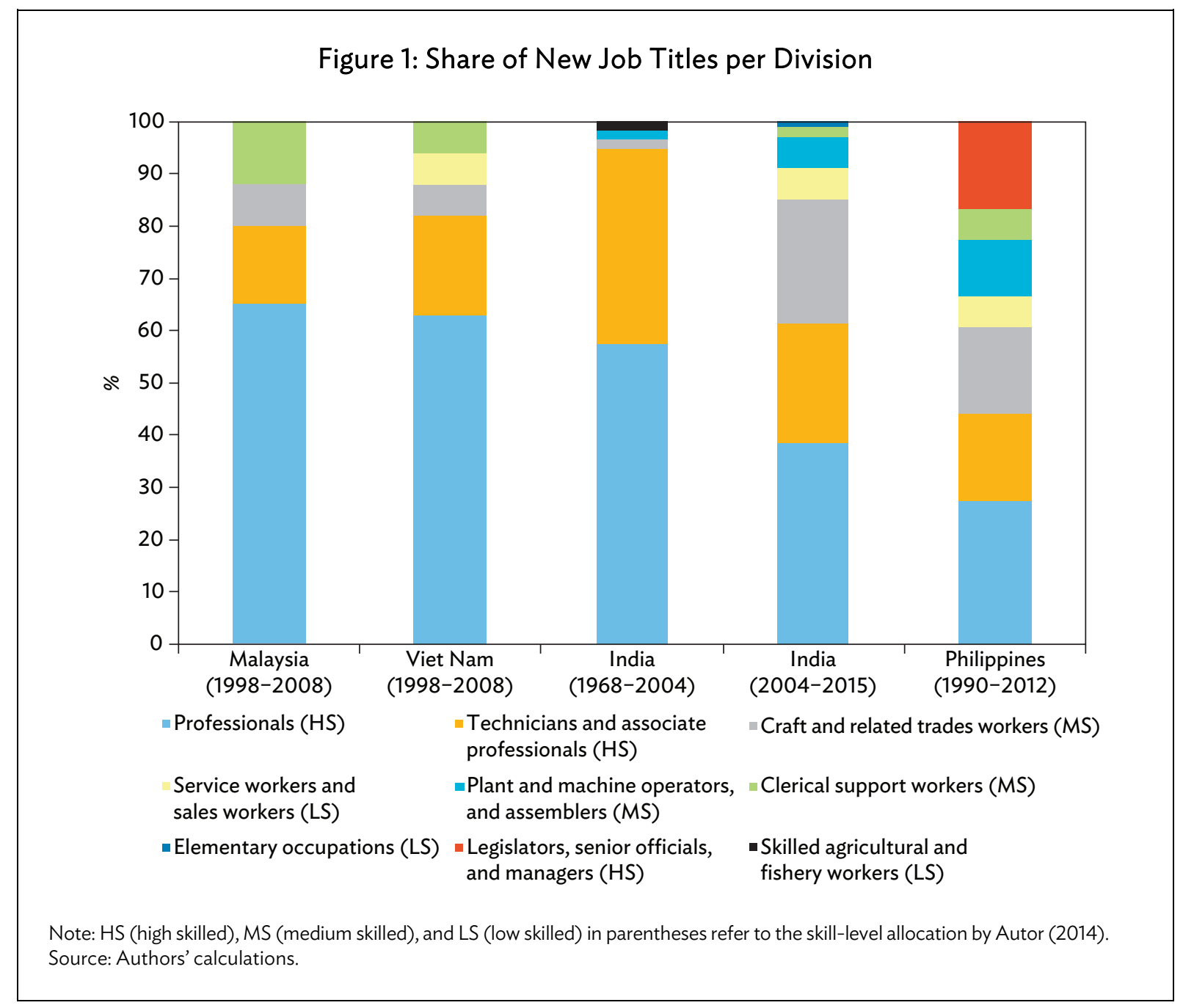

33 The complete list of new job titles is in Appendix 3. These numbers reflect Lin (2011), who, in his analysis of new job titles between 1990 and 2000, identifies 840 out of 30,900 (2.7\%) as new occupations.

34 The different NCOs examined have different levels of exhaustiveness in terms of the disaggregation of job title codes, so the total number of new job titles may vary largely across countries. Naturally, greater total numbers of job titles or emerging occupations do not necessarily mean that there are more people holding new job titles or emerging occupation groups in the country. 
A closer look reveals that many of the new job titles identified are high skilled and directly related to ICT and the use of personal computers, reflecting rapid advances in digital technology in the 1980s and resembling Lin's (2011) findings in the US in 1977. Most of the new job titles include engineering and data analyst positions such as software engineers, system programmers, database design analysts, computer system hardware analysts, computer quality assurance analysts, and computer security specialists. Aside from professionals and technicians and associate professionals, a third division, craft and related trades workers (middle skilled), specifically electrical trade workers, also holds significant shares of new job titles in India 2004-2015 and the Philippines. Interestingly, majority of the new job titles in this division in the case of India 2004-2015 are computer numerical control (CNC) technicians, who are machinists whose jobs entail operating computer-driven machine tools. ${ }^{35}$ In the Philippines, new job titles falling under the craft and related trades workers are mainly electrical technicians. By contrast, only a few new job titles have emerged among clerical support workers and service and sales workers, and almost none under elementary occupation workers despite employment growing in these occupations. ${ }^{36}$ Figure 2 , which follows Autor's (2014) classification of occupation groups by skill level makes this point more apparent: 62\% of new job titles in India (2004-2015) are classified as high skilled, whereas it is $82 \%$ in Viet Nam (1998-2008), followed by $80 \%$ in Malaysia (1998-2008), and 61\% in the Philippines (1990-2012).

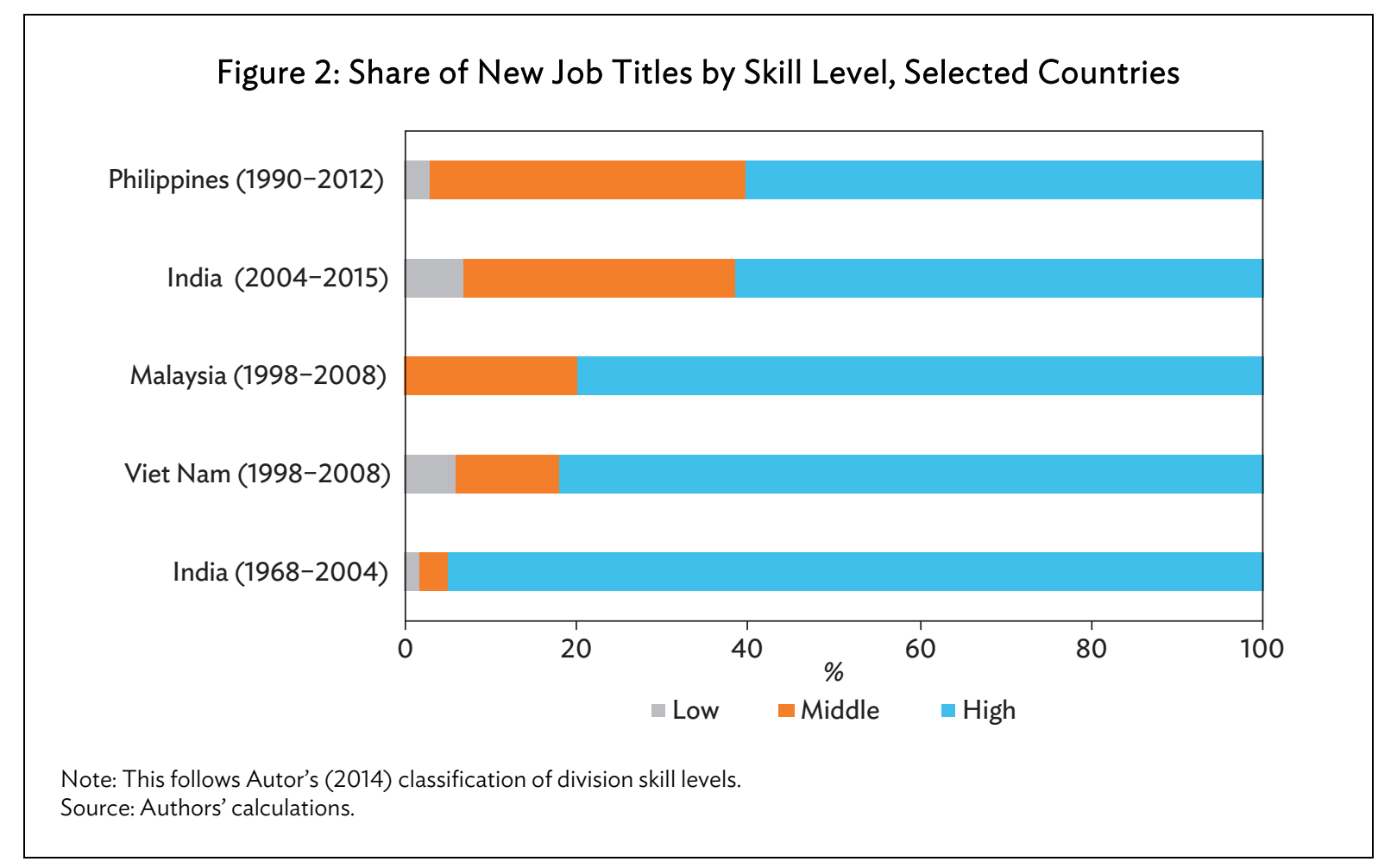

35 Examples of job titles are CNC operator machining technicians, CNC setter-cum-operator-vertical machining center, and CNC programmers. Other new job titles in this occupation group also include smartphone repair technicians, solar panel installation technicians, and optical fiber technicians.

36 E-waste collector, identified as a new job title in India (2004 and 2015 NCOs), is the only new job title under elementary occupation workers. 
When moving the level of analyses of occupation codes from job titles to occupation groups, we find 21 emerging occupations out of 116 (18\%) in India's 2004 NCO and 32 out 127 (25.2\%) in the 2015 NCO. Similarly, we find 17 emerging occupations out of 132 (13.6\%) in the Philippines' 2012 NCO, 13 out of 143 (9.8\%) in Malaysia's 2008 NCO, and 10 out of 191 (5.2\%) in Viet Nam's 2008 NCO. ${ }^{37}$ Figure 3 shows some examples of emerging occupations with the highest proportions of new job titles, most of which are high-skilled and ICT-related occupations. Viet Nam particularly stands out for having high shares of new job titles in ICT-related occupation groups. ${ }^{38}$ Aside from ICT occupations, sales occupations, client information workers, and other STEM-related occupations, particularly physicists and chemists, also have high shares of new job titles.

Figure 3: Selected Emerging Occupations with the Highest Proportion of New Job Titles

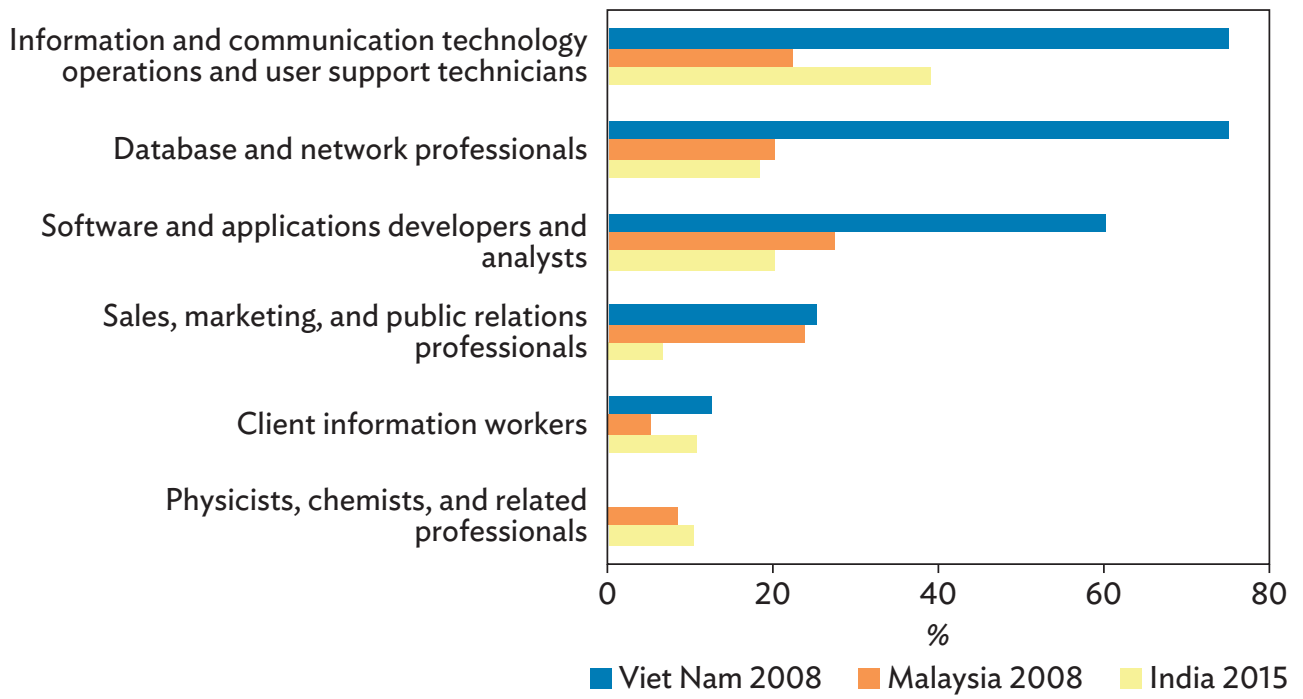

Sources: Calculations are based on comparisons made between 2004 and 2015 National Classification of Occupations (NCOs) for India, 1998 and 2008 NCOs for Malaysia, and 1998 and 2008 NCOs for Viet Nam.

\section{B. Employment Trends in Emerging Occupations: India and Viet Nam}

\section{Employment Levels}

Upon utilizing the microdata of India and Viet Nam, we find that very few workers are in emerging occupations despite these occupation groups paying relatively higher wages than nonemerging occupations. For instance, in 1994 India, we estimate that approximately $1.45 \%$ of the working population or approximately 4 million workers were employed in emerging occupations, $2.08 \%$ (approximately 6.7 million) in 2000, and 3.63\% (approximately 13.5 million) in 2012 (Table 5), whereas relatively lower employment shares of emerging occupation workers are observed in the case of Viet Nam. As seen on Table 6, we estimate that $1.61 \%$ of the working population (approximately

37 The complete list of emerging occupations is in Appendix 4.

38 Viet Nam has become the country with the highest penetration rates of ICT among developing nations (Chun and Tang 2018) after having implemented bold reforms targeting the telecommunications and internet sectors. Some key events include introducing code-division multiple access technology (which allow multiple users to use bandwidth) in 2002 and deploying mobile broadband technology in 2007. 
693,000 workers) were employed in emerging occupations in 2009,1.71\% (approximately 770,000 ) in 2013, and $1.83 \%$ (nearly 1 million) in 2015. Indeed, these low employment shares in emerging occupations may largely be in part due to the lack of skill or talent availability as most new types of work-especially those that involve operating new technologies, would likely require high-skilled workers. This may also alternatively be due to the risk associated with new types of work, or lack of information on behalf of the jobseekers among others.

Table 5: Employment in Emerging Occupations, India

\begin{tabular}{|c|c|c|c|c|c|c|c|}
\hline \multirow[b]{2}{*}{$\begin{array}{l}\text { Occ Grp } \\
\text { Code }\end{array}$} & \multirow[b]{2}{*}{ Emerging Occupation Group } & \multicolumn{2}{|c|}{2012} & \multicolumn{2}{|c|}{2000} & \multicolumn{2}{|c|}{1994} \\
\hline & & $\begin{array}{l}\text { Emp } \\
\text { Level }\end{array}$ & $\begin{array}{c}\text { Emp } \\
\text { Share } \\
(\%)\end{array}$ & $\begin{array}{l}\text { Emp } \\
\text { Level }\end{array}$ & $\begin{array}{c}\text { Emp } \\
\text { Share } \\
(\%)\end{array}$ & $\begin{array}{l}\text { Emp } \\
\text { Level }\end{array}$ & $\begin{array}{c}\text { Emp } \\
\text { Share } \\
(\%)\end{array}$ \\
\hline 122 & $\begin{array}{l}\text { Production and operations department } \\
\text { managers }\end{array}$ & $1,978,369$ & 14.61 & 392,454 & 5.83 & & \\
\hline 211 & Physicists, chemists, and related professionals & 92,073 & 0.68 & 94,864 & 1.41 & 59,540 & 1.48 \\
\hline 212 & $\begin{array}{l}\text { Mathematicians, statisticians, and related } \\
\text { professionals }\end{array}$ & 17,076 & 0.13 & 22,411 & 0.33 & 9,606 & 0.24 \\
\hline 213 & Computing professionals & $1,032,251$ & 7.62 & & & 28,125 & 0.70 \\
\hline 214 & $\begin{array}{l}\text { Architects, engineers, and related } \\
\text { professionals }\end{array}$ & $1,548,348$ & 11.43 & 659,911 & 9.80 & 553,783 & 13.75 \\
\hline 221 & Life science professionals & 146,116 & 1.08 & 62,214 & 0.92 & 59,955 & 1.49 \\
\hline 222 & Health professionals (except nursing) & $1,015,701$ & 7.50 & 721,552 & 10.72 & 556,549 & 13.82 \\
\hline 231 & $\begin{array}{l}\text { College, university, and higher education } \\
\text { teaching professionals }\end{array}$ & 696,594 & 5.14 & 349,858 & 5.20 & 338,676 & 8.41 \\
\hline 244 & Social science and related professionals & 82,445 & 0.61 & 103,071 & 1.53 & 137,874 & 3.42 \\
\hline 245 & Writers and creative or performing artists & 313,632 & 2.32 & 237,321 & 3.53 & 223,463 & 5.55 \\
\hline 311 & Physical and engineering science technicians & 776,288 & 5.73 & 701,321 & 10.42 & & \\
\hline 312 & Computer associate professionals & 222,313 & 1.64 & 74,915 & 1.11 & & \\
\hline 313 & Optical and electronic equipment operators & 378,009 & 2.79 & 276,130 & 4.10 & 185,127 & 4.60 \\
\hline 321 & $\begin{array}{l}\text { Life science technicians and related health } \\
\text { associate professionals }\end{array}$ & 110,603 & 0.82 & & & & \\
\hline 322 & $\begin{array}{l}\text { Modern health associate professionals (except } \\
\text { nursing) }\end{array}$ & 557,626 & 4.12 & 659,703 & 9.80 & 331,764 & 8.24 \\
\hline 341 & Finance and sales associate professionals & $2,006,732$ & 14.82 & 813,186 & 12.08 & 852,401 & 21.17 \\
\hline 342 & Business service agents and trade brokers & 365,060 & 2.70 & & & & \\
\hline 346 & Social work associate professionals & 5,634 & 0.04 & & & & \\
\hline 347 & $\begin{array}{l}\text { Artistic, entertainment, and sports associate } \\
\text { professionals }\end{array}$ & 270,043 & 1.99 & 105,753 & 1.57 & 17,521 & 0.44 \\
\hline \multirow[t]{2}{*}{724} & $\begin{array}{l}\text { Electrical and electronic equipment } \\
\text { mechanics and fitters }\end{array}$ & $1,929,709$ & 14.25 & $1,457,362$ & 21.65 & 673,003 & 16.71 \\
\hline & Total & $13,544,622$ & 100.00 & $6,732,026$ & 100.00 & $4,027,387$ & 100.00 \\
\hline
\end{tabular}

Emp = employment, Occ Grp = occupation group.

Source: Authors' calculations using India 1994, 2000, and 2012 Labor Force Surveys. 
Emerging occupation workers are distributed across 14 occupation groups in 1994, 16 in 2000, and 20 in 2012, most of which belong to high-skill divisions (divisions 1-3 in Autor's classification). $86 \%$ of emerging occupation workers in 2012 are high skilled, $78 \%$ in 2000, and 83\% in 1994. Among the emerging occupation groups, the three that consistently employ at least $10 \%$ of the emerging occupation workers are architects, engineers, and related professionals (high skilled), finance and sales associate professionals (high skilled), and electrical and electronic equipment mechanics and fitters (middle skilled). These groups altogether make up 40\%-50\% of the employment in emerging occupations in each LFS year in India. Other big high-skilled emerging occupation groups (with shares at approximately 10\%) include physical and engineering science technicians, specific to the 2000 LFS, modern health associate professionals (except nursing) in the 1994 and 2000 LFSs, and production and operations department managers, specific to the 2012 LFS.

We identify 10 emerging occupations in the Viet Nam LFSs, where seven are considered high skilled, two are middle skilled, and the remaining one is low skilled. Unlike in the case of India, only $47 \%$ of emerging occupation workers are in high-skilled divisions in Viet Nam 2015, 53\% in 2013, and 47\% in 2009. In addition, emerging occupation workers in Viet Nam are largely concentrated in two occupation groups mostly associated with sales occupations: sales, marketing, and public relations professionals (high skilled), and other sales workers (low skilled) -altogether comprising approximately 50\% of the emerging occupation cohorts in all cases. Other big emerging occupations (with at least 10\% employment shares) include client information workers as well as electronics and telecommunications installers and repairers, both considered middle-skilled occupations, make up approximately 20\%-30\% of all workers employed in emerging occupations in all years studied.

Table 6: Employment in Emerging Occupations, Viet Nam

\begin{tabular}{|c|c|c|c|c|c|c|c|}
\hline \multirow[b]{2}{*}{$\begin{array}{l}\text { Occ Grp } \\
\text { Code }\end{array}$} & \multirow[b]{2}{*}{ Emerging Occupation Group } & \multicolumn{2}{|c|}{2015} & \multicolumn{2}{|c|}{2013} & \multicolumn{2}{|c|}{2009} \\
\hline & & $\begin{array}{l}\text { Emp } \\
\text { Level }\end{array}$ & $\begin{array}{l}\text { Emp } \\
\text { Share } \\
(\%)\end{array}$ & $\begin{array}{l}\text { Emp } \\
\text { Level }\end{array}$ & $\begin{array}{l}\text { Emp } \\
\text { Share } \\
(\%)\end{array}$ & $\begin{array}{l}\text { Emp } \\
\text { Level }\end{array}$ & $\begin{array}{c}\text { Emp } \\
\text { Share } \\
(\%)\end{array}$ \\
\hline 213 & Life science professionals & 36,774 & 3.96 & 41,172 & 5.35 & 31,796 & 4.59 \\
\hline 216 & Architects, planners, surveyors and designers & 48,903 & 5.27 & 50,998 & 6.63 & 55,507 & 8.01 \\
\hline 235 & $\begin{array}{l}\text { Teaching professionals not elsewhere } \\
\text { classified }^{\mathrm{a}}\end{array}$ & 47,943 & 5.16 & 60,754 & 7.90 & 33,042 & 4.77 \\
\hline 243 & $\begin{array}{l}\text { Sales, marketing, and public relations } \\
\text { professionals }\end{array}$ & 203,502 & 21.91 & 173,887 & 22.61 & 118,557 & 17.12 \\
\hline 251 & $\begin{array}{l}\text { Software and applications developers and } \\
\text { analysts }\end{array}$ & 43,792 & 4.72 & 28,676 & 3.73 & 22,895 & 3.31 \\
\hline 252 & Database and network professionals & 30,579 & 3.29 & 31,744 & 4.13 & 29,737 & 4.29 \\
\hline 351 & $\begin{array}{l}\text { Information and communication } \\
\text { technology operations and user support } \\
\text { technicians }\end{array}$ & 27,807 & 2.99 & 20,746 & 2.70 & 30,891 & 4.46 \\
\hline 422 & Client information workers & 88,850 & 9.57 & 63,717 & 8.29 & 75,561 & 10.91 \\
\hline 524 & Other sales workers & 238,280 & 25.66 & 203,119 & 26.41 & 231,528 & 33.42 \\
\hline 742 & $\begin{array}{l}\text { Electronics and telecommunications } \\
\text { installers and repairers }\end{array}$ & 162,251 & 17.47 & 94,216 & 12.25 & 63,169 & 9.12 \\
\hline & Total & 928,681 & 100.00 & 769,029 & 100.00 & 692,683 & 100.00 \\
\hline
\end{tabular}

Emp = employment, Occ Grp = occupation group.

${ }^{a}$ Example of new job title identified: information technology trainer.

Source: Authors' calculations using Viet Nam 2009, 2013, and 2015 Labor Force Surveys. 


\section{Wages}

The analyses of India and Viet Nam's LFSs find evidence that wages of wageworkers in new types of work are higher than non-new work. ${ }^{39}$ For instance, Panels A and B of Figure 4 show that emerging occupation wageworkers earn more (with the exception of managers in India 2012) than those who are not, across all divisions where emerging occupations have been identified. Looking at the average monthly wages of wageworkers holding the two types of job titleholders (new and preexisting) within emerging occupations also yield similar results in that new job titleholders among emerging occupation wageworkers seem to generally earn higher wages than preexisting job titleholders in emerging occupations (Appendix 5). ${ }^{40}$

\section{Figure 4: Average Monthly Wages of Wageworkers by Division}

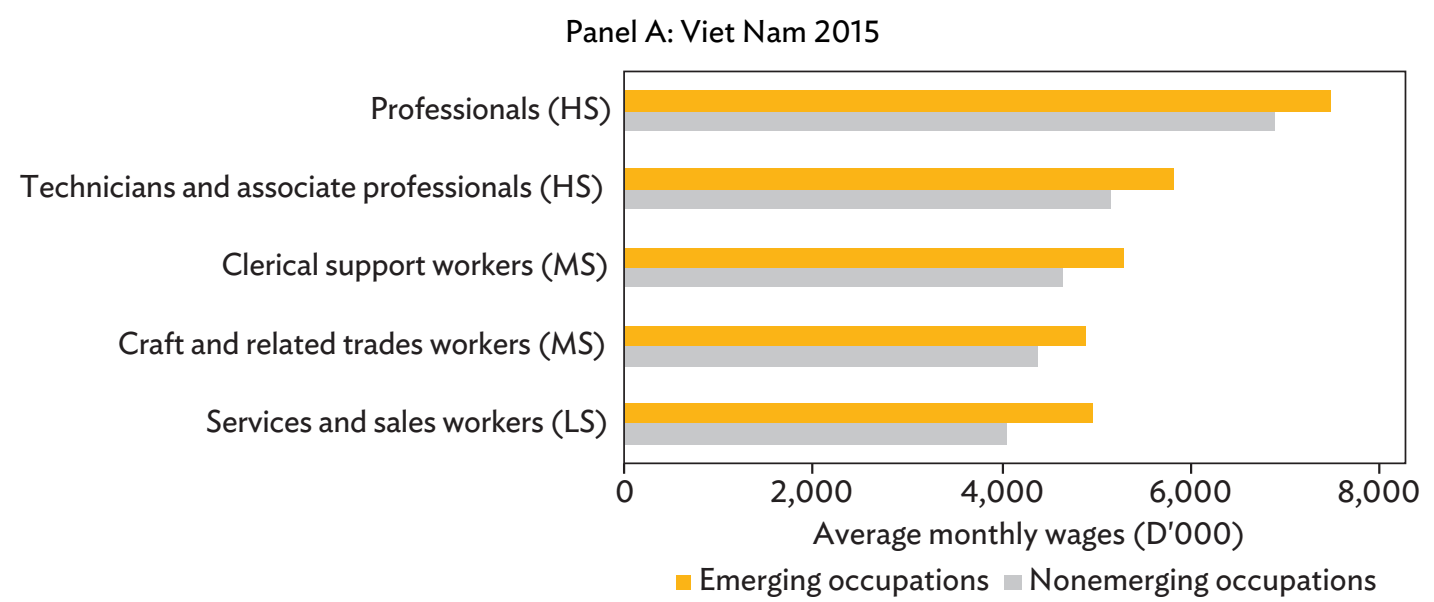

continued on next page

39 The wage premium associated with new types of work may be due to several reasons. First, it may be because the skills of people in new types of work (e.g., workers with certain skills to operate new types of technology) are not as readily available or easily found in the labor market. It could also be because of the relatively higher productivity of workers in emerging occupations (as most are high skilled). In addition, as Lin (2011) notes, this wage premium could also be due to the risk associated with new types of activities, i.e., who knows if a certain technology works?

40 Interestingly, examining observationally comparable workers in similar new and preexisting ICT professional job titles also yields similar results. For instance, Appendix 6 shows that emerging occupation wageworkers, who are urban based and have some form of tertiary education on average, earn higher average monthly wages than observationally similar wageworkers, who are also urban based and have the same educational level, but who are not in emerging occupation groups. 
Figure 4 continued

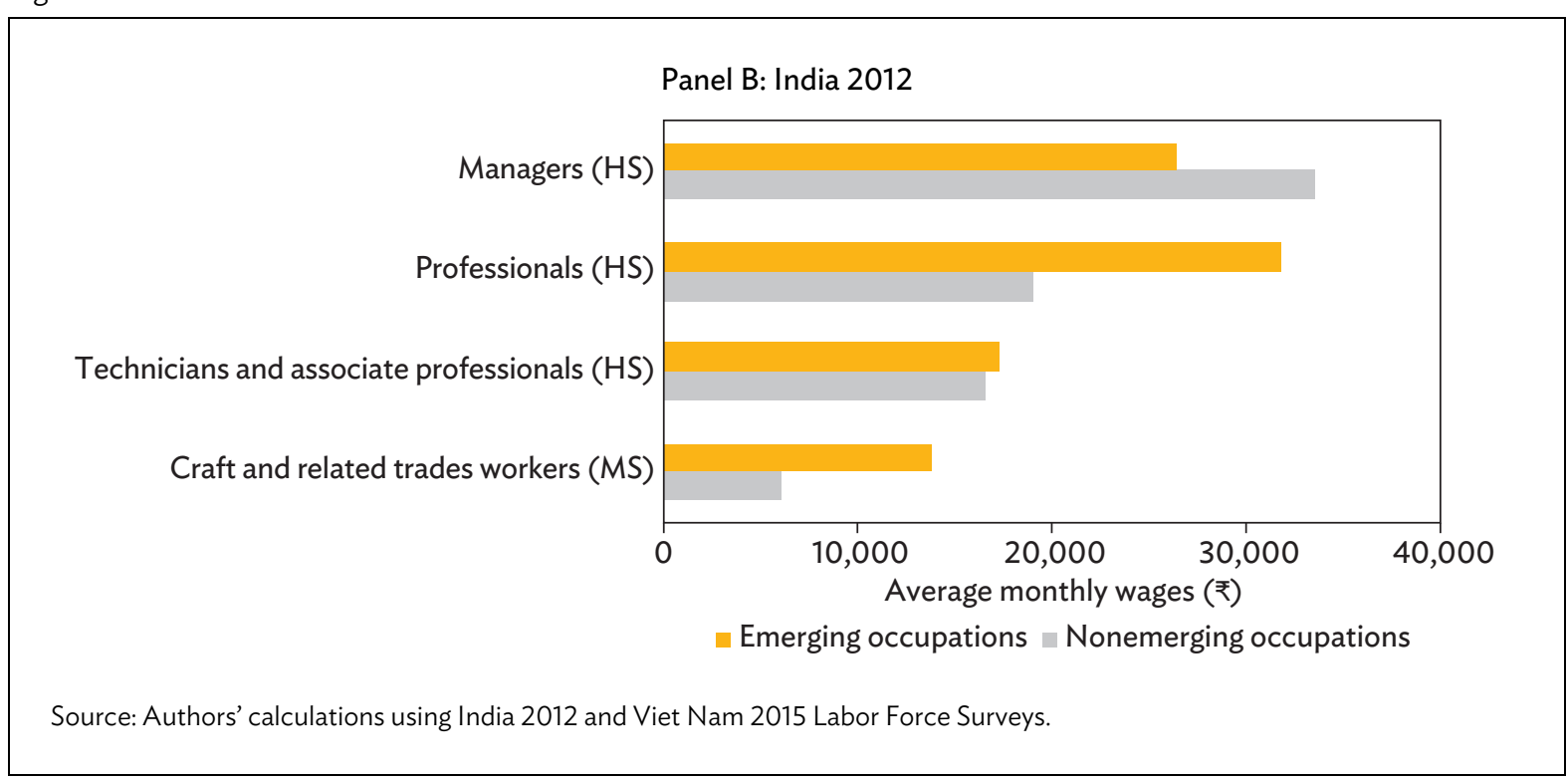

We also find similar results when looking at average monthly wages of wageworkers by sector (Figure 5). For instance, in the case of India, the average monthly wage earned by emerging occupation wageworkers in the manufacturing (services) sector is, on average, approximately 3.5 (2) times more than those in nonemerging occupations in the same industries (Panel A, Figure 5). A closer look into the services industry (Panel A, Appendix 7) also shows that emerging occupation wageworkers in the transport and construction industries earn as much as 3 times and 4 times more, respectively, than nonemerging occupation wageworkers (in the same industries). Similarly, in the case of Viet Nam (Panel B, Figure 5), wageworkers in new job titles and emerging occupations in the manufacturing (services) sectors earn approximately 1.4-1.5 times (1.2-1.3) more than the average monthly wages of those who are not. ${ }^{41}$

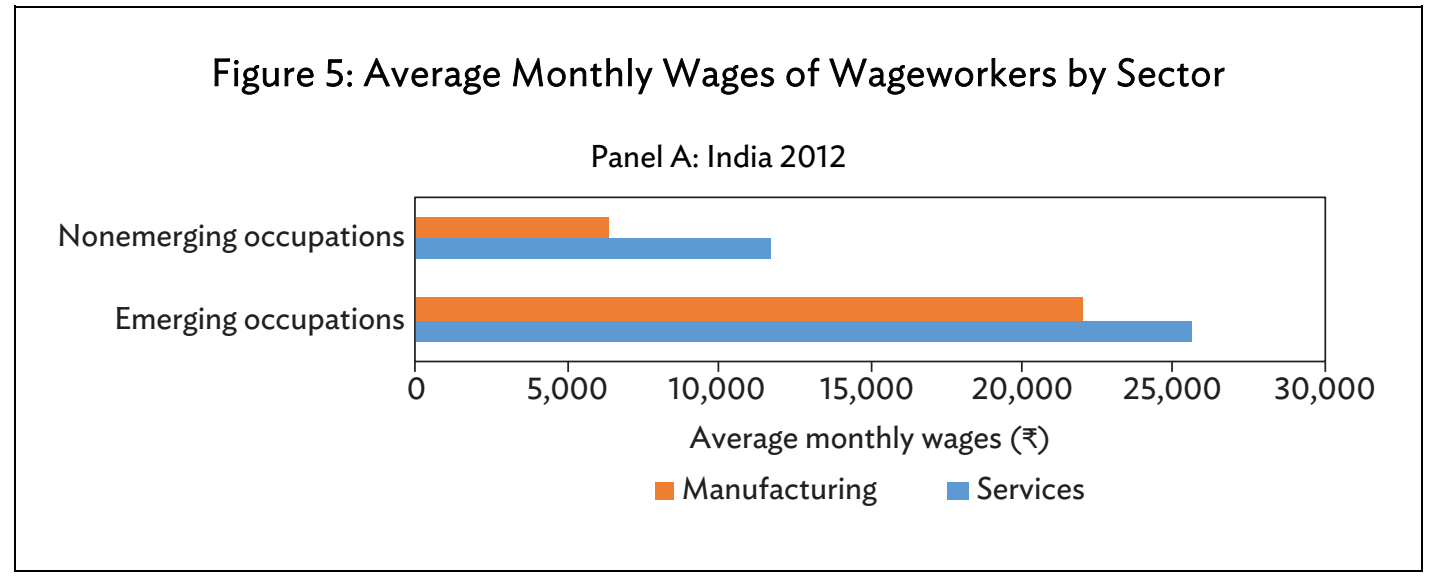

continued on next page

\footnotetext{
41 A closer look into this, using a more disaggregated classification of industries, reveals that emerging occupation workers in the construction industry earn up to 1.7 times more than the average monthly wages of those who are not (Panel B, Appendix 7).
} 
Figure 5 continued

\begin{tabular}{|r|r|r|}
\hline & Panel B: Viet Nam 2015 \\
Nonemerging occupations & Average monthly wages (D'000) \\
Emerging occupations & Services \\
Notes: Agricultural workers are excluded because they are mostly self-employed. \\
Source: Authors' calculations using India 2012 and Viet Nam 2015 Labor Force Surveys.
\end{tabular}

\section{Characteristics of Emerging Occupation Cohorts}

Panels A-F, Figure 6 show the trends in the characteristics of the emerging occupation cohorts, and the trends generally follow what one would expect given the existing literature. In terms of sector, we find most emerging occupation workers in the manufacturing and service sectors (Panel A, Figure 6). Albeit only marginally, it is also worth noting that the employment shares of emerging occupation workers in the service (manufacturing) sectors in both countries are decreasing (increasing) over time. Not surprisingly, emerging occupation workers are also more prevalent in urban areas in that 65\%-70\% are urban based, and these estimates remain relatively stable over the years (Panel B, Figure 6). In terms of education, we find that majority of emerging occupation cohorts in both India and Viet Nam have high educational attainments (Panel C, Figure 6). For instance, 90\% of emerging occupation workers in Viet Nam 2015 have at least a secondary level of education, of which 58\% are tertiary educated. In India 2012, 84\% have at least secondary educational attainment, of which $62 \%$ are tertiary educated. This may not be surprising as most emerging occupations identified in the previous exercises are high-skilled occupations and likely require formal education and training.

In terms of age group, most emerging occupation workers belong to the 25-34 and 35-44 age groups (Panel D, Figure 6). The shares of workers in these two age groups in India do not vary much across all LFS years studied, with shares hovering around 31\%-34\% and $27 \%-29 \%$, respectively. Similar patterns are observed in Viet Nam with 40\%-45\% belonging to the 25-34 age bracket and about 21\%$25 \%$ belonging to the $35-44$ age bracket across all LFS years. One might also have expected the shares of the lower age groups to increase across time as found in Peng, Anwar, and Kang (2017), but the emerging occupation employment shares remain relatively stable across all age groups in both countries over time. In terms of marital status and considering the age group distributions, most emerging occupation workers are married, followed by workers who are single (Panel E, Figure 6). 


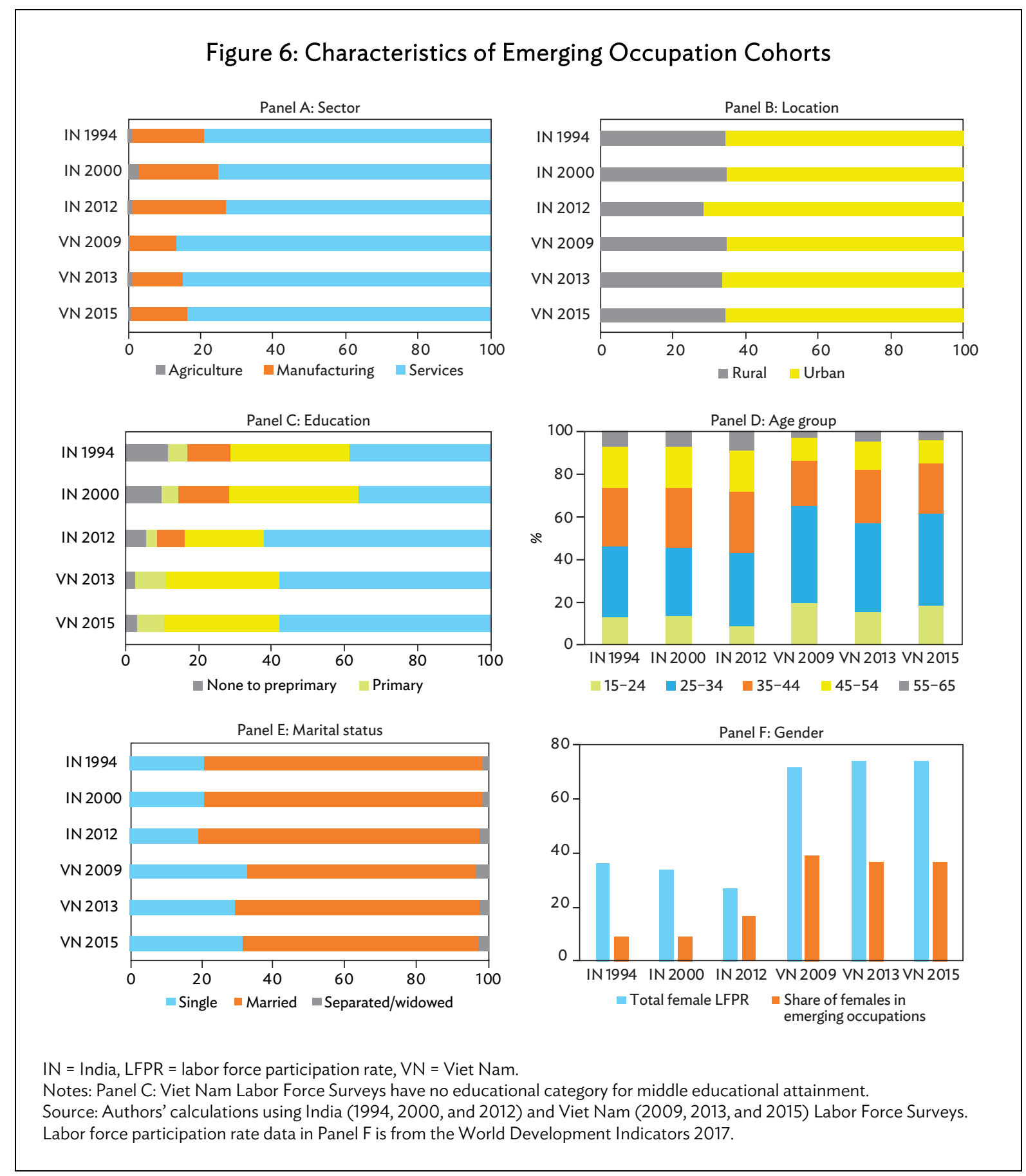

Last, findings in terms of gender reflect those in existing literature in that men have greater access to emerging occupations than women in both India and Viet Nam (Panel F, Figure 6). Despite this, Viet Nam still has relatively high shares of females in emerging occupations; India, on the other hand, does not. In fact, India presents us a particularly interesting case. Despite total female labor force participation rates declining over the years from 36\% in 1994 to 27\% in 2012 (World Bank 2017), women nevertheless seem to be gaining better access to emerging occupations-from 9\% in 1994 to 
$17 \%$ in $2012 .{ }^{42}$ However, a closer look into this reveals that these are mostly women with higher educational attainments; 61\% of female emerging occupation workers in 2012 India and 62\% in 2015 Viet Nam have some form of tertiary education.

\section{Access to Emerging Occupations}

Thus far, the trends presented give us a general idea of how the variables of interest might affect a worker's chances of accessing emerging occupations, but a deeper understanding of this merits a more thorough analysis. In particular, by how much does possessing a certain type of characteristic (relative to another category) increase or decrease a worker's chances of accessing emerging occupations? More importantly, how do predicted probabilities change, depending on the different levels and combinations of the variables of interest? Recall that the results in the succeeding parts of this analysis are predicted probabilities of hypothetical workers, whose chances are necessarily conditional on the independent variables, and not something that exists outside of the model. All persons with the same characteristics share the same chance, such that the logistic regression model interpreted in terms of chance is a "population averaged model." 43 In interpreting the results, it is important to keep in mind the types of emerging occupations identified in the two countries (and years) and how they differ. ${ }^{44}$

Table 7 reports the coefficients and odds ratios of the logit models in the case of India. Standard errors are robust and adjusted for the clustered nature of the samples, and sample weights are applied. All models pass McFadden's pseudo R-squared threshold of 0.2 indicating "excellent fit" (Louviere, Hensher, and Swait 2000; McFadden 1974). ${ }^{45}$ Controlling for region, results for India show that, in 2000, the odds of $y=1$ of workers in the service (manufacturing) sector is approximately 22.6 (14.6) times greater than the odds of an agricultural worker, and these odds go up to 27.4 (21.4) times greater in 2012. The odds of males to access emerging occupations are 1.7 times greater than females in 2000 (whereas the results for 2012 are not significant). Other factors that also increase the probability of selection into emerging occupations are being an urban worker (instead of being a rural worker), and being single (instead of being married or separated, divorced, or widowed). As in Lin (2011), urban workers have better chances than their rural counterparts when it comes to accessing emerging occupations. The odds of someone who is urban based is also 1.2 times greater than the odds of someone who is rural based in 2000 and 1.5 times greater in 2012. Similarly, being married or separated, divorced, or widowed (instead of being single) decreases the probability of selection into emerging occupations for India 2000, whereas the effect of being married or separated (instead of being single) in India 2012 is not significant and thus ambiguous.

When it comes to educational attainment, the odds of tertiary-educated workers in 2000 are 13 times greater than the odds of a worker with none to preprimary levels of education, and these odds

42 One of the more paradoxical trends in India is the decreasing female labor force participation rate despite strong economic growth. Most studies such as Dasgupta and Verick (2016) point to four possible explanations: (i) increased enrollment in secondary schooling, (ii) rising household incomes (which pull women out of the drudgery of agricultural labor), (iii) mismeasurement of women's participation in the labor force; and (iv) the lack of employment opportunities for women in the nonfarm sector.

43 We also run one logit model for each country by stacking the various datasets and adding interaction terms for the variable year. This allows us to have a test of the ratios between the different years. We find that the estimates across the years are the same (marginal differences) as when running three logit models per country and LFS year. The differences (ratios) across the different years are significant. (Appendixes 9-10).

44 We interchange the terms "accessing emerging occupations" and " $y=1$ " in the subsequent sections.

45 McFadden (1974) describes a pseudo R-squared value between 0.2 and 0.4 as an "excellent fit" (Louviere, Hensher, and Swait 2000). The likelihood of pweighted or clustered maximum likelihood estimations is not a true likelihood, i.e., not the distribution of the sample so we do not use standard likelihood ratio tests. 
later increase to 18.7 times greater in year 2012. On the other hand, the odds of secondary-educated workers are only 6.5 times greater in 2000 and 4.7 times greater in 2012 relative to none to preprimary levels. Moreover, in 2000, only estimates for the 25-34 age group are significant, being 1.2 times greater than the odds of the base category, a worker in the 15-24 age bracket. Interestingly, in 2012, the odds of accessing emerging occupations relative to a worker in the 15-24 age bracket increase as the age group increases. The odds of a worker in the 25-34 age group are 1.5 times greater than the base category, and these odds increase up to 2 times greater when the worker is aged 55-65. These findings are indeed contrary to what one would have generally presumed, considering the literature regarding older age and technology. However, it may be argued that these results are, to an extent, what might be expected considering that the types of occupation groups that have been categorized as emerging occupations in India are predominantly classified as high-skilled occupations, whose entry likely requires formal education and training. For instance, recall that three out of the four occupation groups that employ at least 10\% of emerging occupation workers in 2012 are architects, engineers, and related professionals, finance and sales associate professionals, production and operations department managers. Similarly, in 2000, four out of five of the big emerging occupation groups are high skilled which includes the three mentioned in 2012, as well as modern health associate professionals (except nursing), and physical and engineering science technicians.

Table 8 reports the coefficients and odds ratios of the logit models in the case of Viet Nam. Standard errors are robust and adjusted for the clustered nature of the samples, and sample weights are applied. The models used also pass McFadden's pseudo R-squared threshold of 0.2 indicating "excellent fit" (Louviere, Hensher, and Swait 2000; McFadden 1974). Controlling for region, results for Viet Nam show that, once again, a worker's sector of employment have great effects on his or her chances of entering emerging occupations. In particular, in 2013, the odds of workers in the service (manufacturing) sector to access emerging occupations is 36.7 (11) times greater than the odds of an agricultural worker, and these odds go up to 46 (14.8) in 2015. Once again, the effects of being male on $y$ are positive and significant. The odds of $y=1$ for males are 1.8 times greater than the odds of $y$ of females in both years. We observe a similar effect in terms of sign and significance when looking at the location variable in that urban workers have greater chances to enter emerging occupations than rural workers do. For both years, the odds of $y=1$ of urban-based workers are also nearly 1.5 times greater than the odds of rural workers. In terms of marital status, being married (as opposed to being single) once again decreases a worker's chances of entering emerging occupations. In particular, the odds of $y$ of married workers are only approximately 0.83 times (in 2013) and 0.75 times (in 2015) the odds of $y$ of a worker who is single. The probabilities of $y=1$ of separated, divorced, or widowed workers are also lower than the probabilities of workers who are single at 0.75 times, and the effects are only significant in 2013.

Results for age group in 2013 and 2015 are similar in the sense that the odds of workers who are aged 25-34 (35-44) are approximately 1.3 (1.2 in 2015) times greater than 15-24 year olds, while the estimates for the higher age brackets are not significant, and thus ambiguous. In terms of education, workers in 2013 and 2015 with some form of tertiary education only has 3.4 and 2.7 times, respectively, greater odds to access emerging occupations relative to workers with no education. Interestingly, the two largest emerging occupations employment in the Viet Nam cases are sales, marketing, and public relations professionals and other sales workers, comprising approximately $50 \%$ of the total emerging occupations employment. Aside from workers in the services industry being generally younger, entry into sales occupations is also arguably often not restricted by formal education in higher institutions, unlike the emerging occupation groups identified in India. Thus, perhaps, many relatively younger workers are able to take on jobs within these emerging occupation groups. 
Table 7: Estimates from Logit Model of Occupation Selection, India 2000 and 2012

Dependent variable $=1$ if employed in emerging occupation (employed $\rangle=15$ and $\langle=65$ years)

\begin{tabular}{|c|c|c|c|c|c|c|c|c|c|c|c|c|}
\hline & \multicolumn{4}{|c|}{$(0)$} & \multicolumn{4}{|c|}{ (1) } & \multicolumn{4}{|c|}{ (2) } \\
\hline & \multicolumn{2}{|c|}{2000} & \multicolumn{2}{|c|}{2012} & \multicolumn{2}{|c|}{2000} & \multicolumn{2}{|c|}{2012} & \multicolumn{2}{|c|}{2000} & \multicolumn{2}{|c|}{2012} \\
\hline & Coef & OR & Coef & OR & Coef & OR & Coef & OR & Coef & OR & Coef & OR \\
\hline Manufacturing & $\begin{array}{c}2.679^{* * *} \\
(0.133)\end{array}$ & $\begin{array}{c}14.57^{* * *} \\
(1.942)\end{array}$ & $\begin{array}{l}3.071^{* * *} \\
(0.244)\end{array}$ & $\begin{array}{l}21.56^{* * *} \\
(5.263)\end{array}$ & $\begin{array}{c}2.680^{* * *} \\
(0.133)\end{array}$ & $\begin{array}{c}14.59^{* * *} \\
(1.944)\end{array}$ & $\begin{array}{l}3.071^{* * *} \\
(0.244)\end{array}$ & $\begin{array}{l}21.56^{* * *} \\
(5.264)\end{array}$ & $\begin{array}{c}2.680^{* * *} \\
(0.135)\end{array}$ & $\begin{array}{c}14.58^{* * *} \\
(1.970)\end{array}$ & $\begin{array}{c}3.062^{* * *} \\
(0.248)\end{array}$ & $\begin{array}{l}21.36^{* * *} \\
(5.297)\end{array}$ \\
\hline Services & $\begin{array}{l}3.120^{* * *} \\
(0.180)\end{array}$ & $\begin{array}{c}22.65^{* * *} \\
(4.072)\end{array}$ & $\begin{array}{c}3.307^{* * *} \\
(0.234)\end{array}$ & $\begin{array}{c}27.30^{* * *} \\
(6.393)\end{array}$ & $\begin{array}{l}3.120^{* * *} \\
(0.180)\end{array}$ & $\begin{array}{l}22.64^{* * *} \\
(4.066)\end{array}$ & $\begin{array}{c}3.307^{* * *} \\
(0.234)\end{array}$ & $\begin{array}{c}27.30^{* * *} \\
(6.393)\end{array}$ & $\begin{array}{l}3.118^{* * *} \\
(0.180)\end{array}$ & $\begin{array}{c}22.60^{* * *} \\
(4.058)\end{array}$ & $\begin{array}{c}3.309^{* * *} \\
(0.235)\end{array}$ & $\begin{array}{r}27.36^{* * *} \\
(6.431)\end{array}$ \\
\hline Age group 25-34 & $\begin{array}{l}0.309^{* * *} \\
(0.0897)\end{array}$ & $\begin{array}{c}1.362^{* * *} \\
(0.122)\end{array}$ & $\begin{array}{c}0.417^{* * *} \\
(0.123)\end{array}$ & $\begin{array}{l}1.518^{* * *} \\
(0.187)\end{array}$ & $\begin{array}{c}0.202^{* *} \\
(0.0897)\end{array}$ & $\begin{array}{l}1.223^{* *} \\
(0.110)\end{array}$ & $\begin{array}{c}0.424^{* * *} \\
(0.125)\end{array}$ & $\begin{array}{c}1.528^{* * *} \\
(0.191)\end{array}$ & $\begin{array}{c}0.200^{* *} \\
(0.0896)\end{array}$ & $\begin{array}{c}1.221^{* *} \\
(0.109)\end{array}$ & $\begin{array}{c}0.430^{* * *} \\
(0.125)\end{array}$ & $\begin{array}{l}1.537^{* * *} \\
(0.192)\end{array}$ \\
\hline Age group 35-44 & $\begin{array}{c}0.373^{* * *} \\
(0.0827)\end{array}$ & $\begin{array}{l}1.452^{* * *} \\
(0.120)\end{array}$ & $\begin{array}{c}0.421^{* * *} \\
(0.126)\end{array}$ & $\begin{array}{l}1.523^{* * *} \\
(0.192)\end{array}$ & $\begin{array}{r}0.127 \\
(0.123)\end{array}$ & $\begin{array}{r}1.135 \\
(0.140)\end{array}$ & $\begin{array}{l}0.437^{* *} \\
(0.173)\end{array}$ & $\begin{array}{l}1.548^{* *} \\
(0.267)\end{array}$ & $\begin{array}{r}0.127 \\
(0.123)\end{array}$ & $\begin{array}{r}1.135 \\
(0.139)\end{array}$ & $\begin{array}{c}0.455^{* * *} \\
(0.171)\end{array}$ & $\begin{array}{l}1.577^{* * *} \\
(0.269)\end{array}$ \\
\hline Age group 45-54 & $\begin{array}{l}0.526^{* * *} \\
(0.0919)\end{array}$ & $\begin{array}{l}1.691^{* * *} \\
(0.155)\end{array}$ & $\begin{array}{c}0.503^{* * *} \\
(0.143)\end{array}$ & $\begin{array}{l}1.653^{* * *} \\
(0.237)\end{array}$ & $\begin{array}{r}0.133 \\
(0.172)\end{array}$ & $\begin{array}{r}1.142 \\
(0.196)\end{array}$ & $\begin{array}{l}0.530^{* *} \\
(0.229)\end{array}$ & $\begin{array}{l}1.699^{* *} \\
(0.389)\end{array}$ & $\begin{array}{r}0.129 \\
(0.173)\end{array}$ & $\begin{array}{r}1.137 \\
(0.196)\end{array}$ & $\begin{array}{l}0.552^{* *} \\
(0.228)\end{array}$ & $\begin{array}{l}1.737^{* *} \\
(0.396)\end{array}$ \\
\hline Age group 55-65 & $\begin{array}{c}0.527^{* * *} \\
(0.115)\end{array}$ & $\begin{array}{c}1.694^{* * *} \\
(0.194)\end{array}$ & $\begin{array}{c}0.623^{* * *} \\
(0.155)\end{array}$ & $\begin{array}{l}1.864^{* * *} \\
(0.289)\end{array}$ & $\begin{array}{r}-0.0146 \\
(0.218)\end{array}$ & $\begin{array}{r}0.985 \\
(0.214)\end{array}$ & $\begin{array}{l}0.660^{* *} \\
(0.300)\end{array}$ & $\begin{array}{l}1.935^{* *} \\
(0.581)\end{array}$ & $\begin{array}{r}-0.0160 \\
(0.222)\end{array}$ & $\begin{array}{r}0.984 \\
(0.218)\end{array}$ & $\begin{array}{l}0.700^{* *} \\
(0.299)\end{array}$ & $\begin{array}{c}2.014^{* *} \\
(0.602)\end{array}$ \\
\hline Male & $\begin{array}{c}0.503^{* * *} \\
(0.102)\end{array}$ & $\begin{array}{c}1.654^{* * *} \\
(0.169)\end{array}$ & $\begin{array}{l}-0.0277 \\
(0.0616)\end{array}$ & $\begin{array}{r}0.973 \\
(0.0599)\end{array}$ & $\begin{array}{c}0.501^{* * *} \\
(0.103)\end{array}$ & $\begin{array}{l}1.651^{* * *} \\
(0.169)\end{array}$ & $\begin{array}{l}-0.0275 \\
(0.0616)\end{array}$ & $\begin{array}{r}0.973 \\
(0.0599)\end{array}$ & $\begin{array}{c}0.519^{* * *} \\
(0.0978)\end{array}$ & $\begin{array}{l}1.681^{* * *} \\
(0.164)\end{array}$ & $\begin{array}{l}0.00976 \\
(0.0631)\end{array}$ & $\begin{array}{r}1.010 \\
(0.0638)\end{array}$ \\
\hline Primary & $\begin{array}{c}0.225^{*} \\
(0.132)\end{array}$ & $\begin{array}{r}1.252^{*} \\
(0.165)\end{array}$ & $\begin{array}{c}0.269^{* *} \\
(0.119)\end{array}$ & $\begin{array}{l}1.309^{* *} \\
(0.156)\end{array}$ & $\begin{array}{l}0.298^{* *} \\
(0.142)\end{array}$ & $\begin{array}{l}1.347^{* *} \\
(0.192)\end{array}$ & $\begin{array}{l}0.264^{* *} \\
(0.129)\end{array}$ & $\begin{array}{l}1.302^{* *} \\
(0.168)\end{array}$ & $\begin{array}{l}0.308^{* *} \\
(0.149)\end{array}$ & $\begin{array}{c}1.361^{* *} \\
(0.203)\end{array}$ & $\begin{array}{l}0.258^{* *} \\
(0.129)\end{array}$ & $\begin{array}{l}1.294^{* *} \\
(0.167)\end{array}$ \\
\hline Middle & $\begin{array}{l}0.972^{* * *} \\
(0.0941)\end{array}$ & $\begin{array}{c}2.642^{* * *} \\
(0.249)\end{array}$ & $\begin{array}{c}0.800^{* * *} \\
(0.136)\end{array}$ & $\begin{array}{c}2.226^{* * *} \\
(0.302)\end{array}$ & $\begin{array}{c}1.090^{* * *} \\
(0.121)\end{array}$ & $\begin{array}{c}2.975^{* * *} \\
(0.359)\end{array}$ & $\begin{array}{c}0.792^{* * *} \\
(0.167)\end{array}$ & $\begin{array}{c}2.207^{* * *} \\
(0.368)\end{array}$ & $\begin{array}{l}1.108^{* * *} \\
(0.128)\end{array}$ & $\begin{array}{c}3.029^{* * *} \\
(0.388)\end{array}$ & $\begin{array}{c}0.766^{* * *} \\
(0.166)\end{array}$ & $\begin{array}{c}2.150^{* * *} \\
(0.357)\end{array}$ \\
\hline Secondary & $\begin{array}{l}1.707^{* * *} \\
(0.109)\end{array}$ & $\begin{array}{l}5.515^{* * *} \\
(0.604)\end{array}$ & $\begin{array}{c}1.585^{* * *} \\
(0.134)\end{array}$ & $\begin{array}{l}4.879^{* * *} \\
(0.652)\end{array}$ & $\begin{array}{c}1.861^{* * *} \\
(0.141)\end{array}$ & $\begin{array}{l}6.431^{* * *} \\
(0.905)\end{array}$ & $\begin{array}{c}1.574^{* * *} \\
(0.181)\end{array}$ & $\begin{array}{c}4.824^{* * *} \\
(0.874)\end{array}$ & $\begin{array}{c}1.872^{* * *} \\
(0.148)\end{array}$ & $\begin{array}{c}6.500^{* * *} \\
(0.960)\end{array}$ & $\begin{array}{c}1.539^{* * *} \\
(0.182)\end{array}$ & $\begin{array}{r}4.660^{* * *} \\
(0.847)\end{array}$ \\
\hline Tertiary & $\begin{array}{l}2.318^{* * *} \\
(0.104)\end{array}$ & $\begin{array}{l}10.16^{* * *} \\
(1.052)\end{array}$ & $\begin{array}{c}2.977^{* * *} \\
(0.129)\end{array}$ & $\begin{array}{l}19.64^{* * *} \\
(2.538)\end{array}$ & $\begin{array}{c}2.548^{* * *} \\
(0.156)\end{array}$ & $\begin{array}{c}12.79^{* * *} \\
(1.990)\end{array}$ & $\begin{array}{c}2.961^{* * *} \\
(0.191)\end{array}$ & $\begin{array}{l}19.31^{* * *} \\
(3.685)\end{array}$ & $\begin{array}{c}2.563^{* * *} \\
(0.159)\end{array}$ & $\begin{array}{l}12.98^{* * *} \\
(2.066)\end{array}$ & $\begin{array}{r}2.929^{* * *} \\
(0.191)\end{array}$ & $\begin{array}{l}18.71^{\text {***}} \\
(3.575)\end{array}$ \\
\hline
\end{tabular}




\begin{tabular}{|c|c|c|c|c|c|c|c|c|c|c|c|c|}
\hline & \multicolumn{4}{|c|}{$(0)$} & \multicolumn{4}{|c|}{ (1) } & \multicolumn{4}{|c|}{$(2)$} \\
\hline & \multicolumn{2}{|c|}{2000} & \multicolumn{2}{|c|}{2012} & \multicolumn{2}{|c|}{2000} & \multicolumn{2}{|c|}{2012} & \multicolumn{2}{|c|}{2000} & \multicolumn{2}{|c|}{2012} \\
\hline & Coef & OR & Coef & OR & Coef & OR & Coef & OR & Coef & OR & Coef & OR \\
\hline Urban & $\begin{array}{c}0.224^{* * *} \\
(0.0676)\end{array}$ & $\begin{array}{c}1.251^{* * *} \\
(0.0846)\end{array}$ & $\begin{array}{c}0.429^{* * *} \\
(0.0833)\end{array}$ & $\begin{array}{c}1.535^{* * *} \\
(0.128)\end{array}$ & $\begin{array}{c}0.221^{* * *} \\
(0.0672)\end{array}$ & $\begin{array}{c}1.247^{* * *} \\
(0.0838)\end{array}$ & $\begin{array}{c}0.429^{* * *} \\
(0.0835)\end{array}$ & $\begin{array}{c}1.536^{* * *} \\
(0.128)\end{array}$ & $\begin{array}{c}0.219^{* * *} \\
(0.0657)\end{array}$ & $\begin{array}{c}1.245^{* * *} \\
(0.0818)\end{array}$ & $\begin{array}{c}0.392^{* * *} \\
(0.0835)\end{array}$ & $\begin{array}{r}1.480^{* * *} \\
(0.124)\end{array}$ \\
\hline Married & $\begin{array}{l}-0.238^{* * *} \\
(0.0860)\end{array}$ & $\begin{array}{c}0.789^{* * *} \\
(0.0678)\end{array}$ & $\begin{array}{r}-0.0814 \\
(0.0912)\end{array}$ & $\begin{array}{r}0.922 \\
(0.0841)\end{array}$ & $\begin{array}{c}-0.266^{* * *} \\
(0.0807)\end{array}$ & $\begin{array}{c}0.766^{* * *} \\
(0.0618)\end{array}$ & $\begin{array}{c}-0.0793 \\
(0.0977)\end{array}$ & $\begin{array}{r}0.924 \\
(0.0903)\end{array}$ & $\begin{array}{c}-0.265^{* * *} \\
(0.0717)\end{array}$ & $\begin{array}{c}0.767^{* * *} \\
(0.0550)\end{array}$ & $\begin{array}{r}-0.0736 \\
(0.0947)\end{array}$ & $\begin{array}{r}0.929 \\
(0.0879)\end{array}$ \\
\hline Separated/widowed & $\begin{array}{c}-0.479^{* *} \\
(0.242)\end{array}$ & $\begin{array}{c}0.620^{* *} \\
(0.150)\end{array}$ & $\begin{array}{r}-0.0749 \\
(0.171)\end{array}$ & $\begin{array}{r}0.928 \\
(0.159)\end{array}$ & $\begin{array}{c}-0.515^{* *} \\
(0.234)\end{array}$ & $\begin{array}{l}0.598^{* *} \\
(0.140)\end{array}$ & $\begin{array}{r}-0.0720 \\
(0.182)\end{array}$ & $\begin{array}{r}0.931 \\
(0.169)\end{array}$ & $\begin{array}{c}-0.515^{* *} \\
(0.223)\end{array}$ & $\begin{array}{l}0.597^{* *} \\
(0.133)\end{array}$ & $\begin{array}{r}-0.0700 \\
(0.181)\end{array}$ & $\begin{array}{r}0.932 \\
(0.169)\end{array}$ \\
\hline Pot. work exp. controls & \multicolumn{2}{|c|}{ No } & \multicolumn{2}{|c|}{ No } & \multicolumn{2}{|c|}{ Yes } & \multicolumn{2}{|c|}{ Yes } & \multicolumn{2}{|c|}{ Yes } & \multicolumn{2}{|c|}{ Yes } \\
\hline Region controls & \multicolumn{2}{|c|}{ No } & \multicolumn{2}{|c|}{ No } & \multicolumn{2}{|c|}{ No } & \multicolumn{2}{|c|}{ No } & \multicolumn{2}{|c|}{ Yes } & \multicolumn{2}{|c|}{ Yes } \\
\hline Observations & \multicolumn{2}{|c|}{275,966} & \multicolumn{2}{|c|}{153,387} & \multicolumn{2}{|c|}{275,966} & \multicolumn{2}{|c|}{153,387} & \multicolumn{2}{|c|}{275,966} & \multicolumn{2}{|c|}{153,387} \\
\hline Wald chi2 $\left(^{*}\right)$ & \multicolumn{2}{|c|}{ (14) 8232.38} & \multicolumn{2}{|c|}{ (14) 2693.78} & \multicolumn{2}{|c|}{ (15) 8258.22} & \multicolumn{2}{|c|}{ (15) 2755.53} & \multicolumn{2}{|c|}{ (19) 10503.25} & \multicolumn{2}{|c|}{ (19) 3027.85} \\
\hline Prob > chi2 & \multicolumn{2}{|c|}{0.000} & 0.0 & & 0. & 00 & 0.0 & & 0.0 & 00 & & 00 \\
\hline Pseudo R-squared & 0.2 & 486 & 0.2 & 65 & 0.2 & 488 & 0.2 & 865 & 0.2 & 499 & 0.2 & 886 \\
\hline
\end{tabular}

Coef = coefficient, $\mathrm{OR}=$ odds ratio.

Notes: Robust standard errors in parentheses. Adjusted for clustering. ${ }^{* *}, * *$, and ${ }^{*}$ indicate significance at $1 \%, 5 \%$, and $10 \%$, respectively. Wald chi2 $\left(^{*}\right)$ in parentheses per model ran.

Pot. work exp. refers to potential years of work experience, which is a generated continuous control variable following the equation: age - years of schooling - 6 , where 6 is assumed to be the age of entry to school. The reference categories for each variable are: 15-24 for age group, female for gender, none to preprimary for education, agriculture for sector, rural for location, single for marital status.

Source: Authors' calculations 
Table 8: Estimates from Logit Model of Occupation Selection, Viet Nam 2013-2015

Dependent variable $=1$ if employed in emerging occupation (employed $>=15$ and $\langle=65$ years)

\begin{tabular}{|c|c|c|c|c|c|c|c|c|c|c|c|c|}
\hline & \multicolumn{4}{|c|}{$(0)$} & \multicolumn{4}{|c|}{ (1) } & \multicolumn{4}{|c|}{ (2) } \\
\hline & \multicolumn{2}{|c|}{2013} & \multicolumn{2}{|c|}{2015} & \multicolumn{2}{|c|}{2013} & \multicolumn{2}{|c|}{2015} & \multicolumn{2}{|c|}{2013} & \multicolumn{2}{|c|}{2015} \\
\hline & Coef & OR & Coef & OR & Coef & OR & Coef & OR & Coef & OR & Coef & OR \\
\hline Manufacturing & $\begin{array}{l}2.537^{* * *} \\
(0.286)\end{array}$ & $\begin{array}{c}12.64^{* * *} \\
(3.610)\end{array}$ & $\begin{array}{c}2.747^{* * *} \\
(0.236)\end{array}$ & $\begin{array}{c}15.60^{* * *} \\
(3.684)\end{array}$ & $\begin{array}{l}2.510^{* * *} \\
(0.282)\end{array}$ & $\begin{array}{l}12.31^{* * *} \\
(3.466)\end{array}$ & $\begin{array}{l}2.751^{* * *} \\
(0.234)\end{array}$ & $\begin{array}{c}15.66^{* * *} \\
(3.672)\end{array}$ & $\begin{array}{l}2.401^{* * *} \\
(0.289)\end{array}$ & $\begin{array}{c}11.03^{* * *} \\
(3.183)\end{array}$ & $\begin{array}{c}2.692^{* * *} \\
(0.250)\end{array}$ & $\begin{array}{l}14.76^{* * *} \\
(3.685)\end{array}$ \\
\hline Services & $\begin{array}{c}3.756^{* * *} \\
(0.332)\end{array}$ & $\begin{array}{c}42.77^{* * *} \\
(14.19)\end{array}$ & $\begin{array}{l}3.877^{* * *} \\
(0.270)\end{array}$ & $\begin{array}{c}48.28^{* * *} \\
(13.04)\end{array}$ & $\begin{array}{c}3.696^{* * *} \\
(0.343)\end{array}$ & $\begin{array}{c}40.29^{* * *} \\
(13.83)\end{array}$ & $\begin{array}{c}3.877^{* * *} \\
(0.269)\end{array}$ & $\begin{array}{c}48.28^{* * *} \\
(12.96)\end{array}$ & $\begin{array}{c}3.603^{* * *} \\
(0.356)\end{array}$ & $\begin{array}{c}36.72^{* * *} \\
(13.08)\end{array}$ & $\begin{array}{c}3.830^{* * *} \\
(0.286)\end{array}$ & $\begin{array}{r}46.07^{* * *} \\
(13.17)\end{array}$ \\
\hline Age group 25-34 & $\begin{array}{r}0.0459 \\
(0.0777)\end{array}$ & $\begin{array}{r}1.047 \\
(0.0814)\end{array}$ & $\begin{array}{r}0.0565 \\
(0.0498)\end{array}$ & $\begin{array}{r}1.058 \\
(0.0527)\end{array}$ & $\begin{array}{l}0.289^{* *} \\
(0.124)\end{array}$ & $\begin{array}{l}1.336^{* *} \\
(0.166)\end{array}$ & $\begin{array}{c}0.262^{* * *} \\
(0.0550)\end{array}$ & $\begin{array}{l}1.299^{* * *} \\
(0.0715)\end{array}$ & $\begin{array}{l}0.263^{* *} \\
(0.105)\end{array}$ & $\begin{array}{l}1.301^{* *} \\
(0.137)\end{array}$ & $\begin{array}{c}0.246^{* * *} \\
(0.0564)\end{array}$ & $\begin{array}{c}1.279^{* * *} \\
(0.0721)\end{array}$ \\
\hline Age group 35-44 & $\begin{array}{c}-0.279^{* * *} \\
(0.0823)\end{array}$ & $\begin{array}{c}0.756^{* * *} \\
(0.0622)\end{array}$ & $\begin{array}{c}-0.269^{* * *} \\
(0.0617)\end{array}$ & $\begin{array}{l}0.764^{* * *} \\
(0.0471)\end{array}$ & $\begin{array}{r}0.357 \\
(0.221)\end{array}$ & $\begin{array}{r}1.429 \\
(0.316)\end{array}$ & $\begin{array}{c}0.226^{* *} \\
(0.112)\end{array}$ & $\begin{array}{l}1.253^{* *} \\
(0.140)\end{array}$ & $\begin{array}{c}0.341^{*} \\
(0.203)\end{array}$ & $\begin{array}{r}1.406^{*} \\
(0.286)\end{array}$ & $\begin{array}{l}0.214^{* *} \\
(0.105)\end{array}$ & $\begin{array}{l}1.238^{* *} \\
(0.130)\end{array}$ \\
\hline Age group 45-54 & $\begin{array}{c}-0.652^{* * *} \\
(0.0961)\end{array}$ & $\begin{array}{c}0.521^{* * *} \\
(0.0500)\end{array}$ & $\begin{array}{l}-0.737^{* * *} \\
(0.0898)\end{array}$ & $\begin{array}{c}0.478^{* * *} \\
(0.0430)\end{array}$ & $\begin{array}{r}0.377 \\
(0.322)\end{array}$ & $\begin{array}{r}1.458 \\
(0.469)\end{array}$ & $\begin{array}{l}0.0637 \\
(0.177)\end{array}$ & $\begin{array}{r}1.066 \\
(0.189)\end{array}$ & $\begin{array}{r}0.377 \\
(0.310)\end{array}$ & $\begin{array}{r}1.459 \\
(0.452)\end{array}$ & $\begin{array}{l}0.0627 \\
(0.173)\end{array}$ & $\begin{array}{r}1.065 \\
(0.184)\end{array}$ \\
\hline Age group 55-65 & $\begin{array}{r}-0.766^{* * *} \\
(0.141)\end{array}$ & $\begin{array}{c}0.465^{* * *} \\
(0.0656)\end{array}$ & $\begin{array}{r}-1.027^{* * *} \\
(0.132)\end{array}$ & $\begin{array}{l}0.358^{* * *} \\
(0.0471)\end{array}$ & $\begin{array}{r}0.649 \\
(0.430)\end{array}$ & $\begin{array}{r}1.914 \\
(0.823)\end{array}$ & $\begin{array}{r}0.0212 \\
(0.246)\end{array}$ & $\begin{array}{r}1.021 \\
(0.251)\end{array}$ & $\begin{array}{r}0.656 \\
(0.424)\end{array}$ & $\begin{array}{r}1.927 \\
(0.817)\end{array}$ & $\begin{array}{r}0.0377 \\
(0.248)\end{array}$ & $\begin{array}{r}1.038 \\
(0.258)\end{array}$ \\
\hline Male & $\begin{array}{c}0.614^{* * *} \\
(0.0429)\end{array}$ & $\begin{array}{c}1.848^{* * *} \\
(0.0794)\end{array}$ & $\begin{array}{c}0.632^{* * *} \\
(0.0506)\end{array}$ & $\begin{array}{c}1.882^{* * *} \\
(0.0952)\end{array}$ & $\begin{array}{l}0.603^{* * *} \\
(0.0441)\end{array}$ & $\begin{array}{c}1.828^{* * *} \\
(0.0806)\end{array}$ & $\begin{array}{c}0.606^{* * *} \\
(0.0505)\end{array}$ & $\begin{array}{c}1.833^{* * *} \\
(0.0926)\end{array}$ & $\begin{array}{c}0.601^{* * *} \\
(0.0443)\end{array}$ & $\begin{array}{c}1.824^{* * *} \\
(0.0808)\end{array}$ & $\begin{array}{c}0.606^{* * *} \\
(0.0500)\end{array}$ & $\begin{array}{c}1.832^{* * *} \\
(0.0916)\end{array}$ \\
\hline Primary & $\begin{array}{r}0.00166 \\
(0.143)\end{array}$ & $\begin{array}{r}1.002 \\
(0.143)\end{array}$ & $\begin{array}{r}-0.167 \\
(0.139)\end{array}$ & $\begin{array}{r}0.846 \\
(0.118)\end{array}$ & $\begin{array}{r}-0.0458 \\
(0.143)\end{array}$ & $\begin{array}{r}0.955 \\
(0.137)\end{array}$ & $\begin{array}{r}-0.290^{* *} \\
(0.143)\end{array}$ & $\begin{array}{l}0.749^{* *} \\
(0.107)\end{array}$ & $\begin{array}{r}-0.0324 \\
(0.152)\end{array}$ & $\begin{array}{r}0.968 \\
(0.147)\end{array}$ & $\begin{array}{c}-0.281^{*} \\
(0.144)\end{array}$ & $\begin{array}{c}0.755^{*} \\
(0.109)\end{array}$ \\
\hline Secondary & $\begin{array}{r}0.238 \\
(0.185)\end{array}$ & $\begin{array}{r}1.268 \\
(0.234)\end{array}$ & $\begin{array}{r}0.207 \\
(0.179)\end{array}$ & $\begin{array}{r}1.230 \\
(0.220)\end{array}$ & $\begin{array}{r}-0.0788 \\
(0.153)\end{array}$ & $\begin{array}{r}0.924 \\
(0.141)\end{array}$ & $\begin{array}{r}-0.0783 \\
(0.179)\end{array}$ & $\begin{array}{r}0.925 \\
(0.165)\end{array}$ & $\begin{array}{r}-0.0383 \\
(0.160)\end{array}$ & $\begin{array}{r}0.962 \\
(0.154)\end{array}$ & $\begin{array}{r}-0.0300 \\
(0.166)\end{array}$ & $\begin{array}{r}0.970 \\
(0.161)\end{array}$ \\
\hline Tertiary & $\begin{array}{c}1.666^{* * *} \\
(0.319)\end{array}$ & $\begin{array}{c}5.291^{* * *} \\
(1.690)\end{array}$ & $\begin{array}{l}1.254^{* * *} \\
(0.225)\end{array}$ & $\begin{array}{c}3.503^{* * *} \\
(0.789)\end{array}$ & $\begin{array}{l}1.166^{* * *} \\
(0.214)\end{array}$ & $\begin{array}{c}3.208^{* * *} \\
(0.688)\end{array}$ & $\begin{array}{l}0.918^{* * *} \\
(0.226)\end{array}$ & $\begin{array}{c}2.504^{* * *} \\
(0.566)\end{array}$ & $\begin{array}{l}1.219^{* * *} \\
(0.207)\end{array}$ & $\begin{array}{l}3.383^{* * *} \\
(0.700)\end{array}$ & $\begin{array}{l}0.981^{* * *} \\
(0.206)\end{array}$ & $\begin{array}{c}2.668^{* * *} \\
(0.550)\end{array}$ \\
\hline Urban & $\begin{array}{c}0.435^{* * *} \\
(0.154)\end{array}$ & $\begin{array}{l}1.545^{* * *} \\
(0.237)\end{array}$ & $\begin{array}{c}0.456^{* * *} \\
(0.122)\end{array}$ & $\begin{array}{c}1.578^{* * *} \\
(0.192)\end{array}$ & $\begin{array}{c}0.452^{* * *} \\
(0.156)\end{array}$ & $\begin{array}{l}1.571^{* * *} \\
(0.244)\end{array}$ & $\begin{array}{c}0.479^{* * *} \\
(0.122)\end{array}$ & $\begin{array}{l}1.615^{* * *} \\
(0.198)\end{array}$ & $\begin{array}{c}0.377^{* * *} \\
(0.126)\end{array}$ & $\begin{array}{c}1.458^{* * *} \\
(0.183)\end{array}$ & $\begin{array}{c}0.423^{* * *} \\
(0.101)\end{array}$ & $\begin{array}{c}1.527^{* * *} \\
(0.154)\end{array}$ \\
\hline
\end{tabular}




\begin{tabular}{|c|c|c|c|c|c|c|c|c|c|c|c|c|}
\hline & \multicolumn{4}{|c|}{$(0)$} & \multicolumn{4}{|c|}{ (1) } & \multicolumn{4}{|c|}{ (2) } \\
\hline & \multicolumn{2}{|c|}{2013} & \multicolumn{2}{|c|}{2015} & \multicolumn{2}{|c|}{2013} & \multicolumn{2}{|c|}{2015} & \multicolumn{2}{|c|}{2013} & \multicolumn{2}{|c|}{2015} \\
\hline & Coef & OR & Coef & OR & Coef & OR & Coef & OR & Coef & OR & Coef & OR \\
\hline \multirow[t]{2}{*}{ Married } & $-0.323^{* * *}$ & $0.724^{* * *}$ & $-0.390^{* * *}$ & $0.677^{* * *}$ & $-0.248^{* * *}$ & $0.780^{* * *}$ & $-0.333^{* * *}$ & $0.717^{* * *}$ & $-0.188^{* * *}$ & $0.828^{* * *}$ & $-0.288^{* * *}$ & $0.750^{* * *}$ \\
\hline & $(0.0702)$ & $(0.0508)$ & $(0.0396)$ & $(0.0268)$ & $(0.0578)$ & $(0.0451)$ & $(0.0383)$ & $(0.0274)$ & $(0.0523)$ & $(0.0433)$ & $(0.0419)$ & $(0.0314)$ \\
\hline \multirow[t]{2}{*}{ Separated/widowed } & $-0.420^{* *}$ & $0.657^{* *}$ & $-0.183^{*}$ & $0.833^{*}$ & $-0.334^{* *}$ & $0.716^{* *}$ & -0.111 & 0.895 & $-0.289^{* *}$ & $0.749^{* *}$ & -0.0668 & 0.935 \\
\hline & $(0.177)$ & $(0.116)$ & $(0.0973)$ & $(0.0811)$ & $(0.152)$ & $(0.109)$ & $(0.0951)$ & $(0.0852)$ & $(0.139)$ & $(0.104)$ & $(0.0844)$ & $(0.0790)$ \\
\hline Pot. work exp. controls & No & No & No & No & Yes & Yes & Yes & Yes & Yes & Yes & Yes & Yes \\
\hline Region controls & No & No & No & No & No & No & No & No & Yes & Yes & Yes & Yes \\
\hline Observations & \multicolumn{2}{|c|}{366,080} & \multicolumn{2}{|c|}{445,828} & \multicolumn{2}{|c|}{366,080} & \multicolumn{2}{|c|}{445,828} & \multicolumn{2}{|c|}{366,080} & \multicolumn{2}{|c|}{445,828} \\
\hline Wald chi2 $\left(^{*}\right)$ & \multicolumn{2}{|c|}{ (13) 2595.44} & \multicolumn{2}{|c|}{ (13) 2225.34} & \multicolumn{2}{|c|}{ (14) 3768.28} & \multicolumn{2}{|c|}{ (14) 2393.91} & \multicolumn{2}{|c|}{ (19) 6062.28} & \multicolumn{2}{|c|}{ (19) 2652.39} \\
\hline Prob > chi2 & \multicolumn{2}{|c|}{0.000} & \multicolumn{2}{|c|}{0.000} & \multicolumn{2}{|c|}{0.000} & \multicolumn{2}{|c|}{0.000} & \multicolumn{2}{|r|}{0.000} & \multicolumn{2}{|c|}{0.000} \\
\hline Pseudo R-squared & \multicolumn{2}{|c|}{0.2283} & \multicolumn{2}{|c|}{0.1999} & \multicolumn{2}{|c|}{0.2367} & \multicolumn{2}{|c|}{0.2073} & \multicolumn{2}{|c|}{0.2395} & \multicolumn{2}{|c|}{0.2087} \\
\hline
\end{tabular}

Coef $=$ coefficient, $\mathrm{OR}=$ odds ratio.

Note: Robust standard errors in parentheses. Adjusted for clustering ***** and * indicate significance at $1 \%, 5 \%$, and $10 \%$, respectively. Wald chi2 $\left.*^{*}\right)$ in parentheses per model ran.

Pot. work exp. refers to potential years of work experience, which is a generated continuous control variable following the equation: age - years of schooling - 6 , where 6 is assumed to be the age of entry to school. The reference categories for each variable are: 15-24 for age group, female for gender, none to preprimary for education, agriculture for sector, rural for location, single for marital status.

Source: Authors' calculations. 


\section{Adjusted Predictions}

We delve further into the effects of the different combinations of sector, education, and age group variables by looking at adjusted predictions. Figure 7 shows the adjusted predictions (keeping all else constant) in the case of India. Panel A shows that, on average, the probability of accessing emerging occupations or $y=1$ is highest among tertiary-educated workers in the service sectors, estimated at $20 \%$ in 2012 and $16 \%-17 \%$ in 1994 . This is followed by tertiary-educated workers in the manufacturing sector whose probability of $y=1$ is predicted at 10\%-11\% in 1994 and 2000 cases and $17 \%$ in 2012. Significantly much lower predicted probabilities are estimated for tertiary-educated workers in the agriculture sector, where there is less than $1 \%$ probability of accessing emerging occupations. The same trends are observed for all other educational attainment groups, wherein the probability of $y=1$ decreases from services to manufacturing to agriculture. In fact, a worker's chance of accessing emerging occupation is (almost) zero if the worker is in agriculture, regardless of his or her educational attainment. Workers with less than middle school educational attainment have less than $5 \%$ chance of accessing emerging occupations in all sectors.

These findings are in line with our hypothesis and the existing literature, given the fact that 85\% (83\%) of the emerging occupation workers in India 2012 (1994) belong to professionals or associate professionals divisions (high skilled). In 2012, the four largest emerging occupation groups are architects, engineers, and related professionals; production and operations department managers; finance and sales associate professionals; electrical and electronic equipment mechanics and fitters. Similar big emerging occupation groups are found in 1994 (excluding production and operations department managers), including modern health associate professionals (except nursing).

Panel B delves deeper into the estimations provided in Panel A and shows how adjusted predictions by sector and educational attainment vary by age groups. Interestingly, tertiary-educated workers in the service sector belonging to the 55-65 age group have the highest predicted probabilities at approximately $25 \%$. This is followed by workers in the $45-54$ age group (second), and then by the 35-44 (third) and 25-34 (fourth) age groups, while those in the 15-24 age bracket have the second to the lowest predicted probabilities. Tertiary-educated workers in the manufacturing sector belonging to the 45-54 age group comes fifth in terms of probabilities of accessing emerging occupations.

These findings are somewhat contrary to what one might have expected, considering the existing literature on technology and age, which revolves around skill obsolescence and adaptability problems of older workers in the labor market. As seen above, hypothetical workers belonging to older age groups have the highest predicted probabilities to access emerging occupations in India 2012, especially among those who are tertiary educated. However, as mentioned previously, these findings may not be that surprising, considering that $85 \%$ of the emerging occupation workers in India are categorized as professionals or associate professionals (high skilled), of which approximately $41 \%$ are architects, engineers, and related professionals, production and operations department managers, and finance and sales associate professionals. These types of occupations and positions are likely those that place great importance to formal education or training and work experience. 


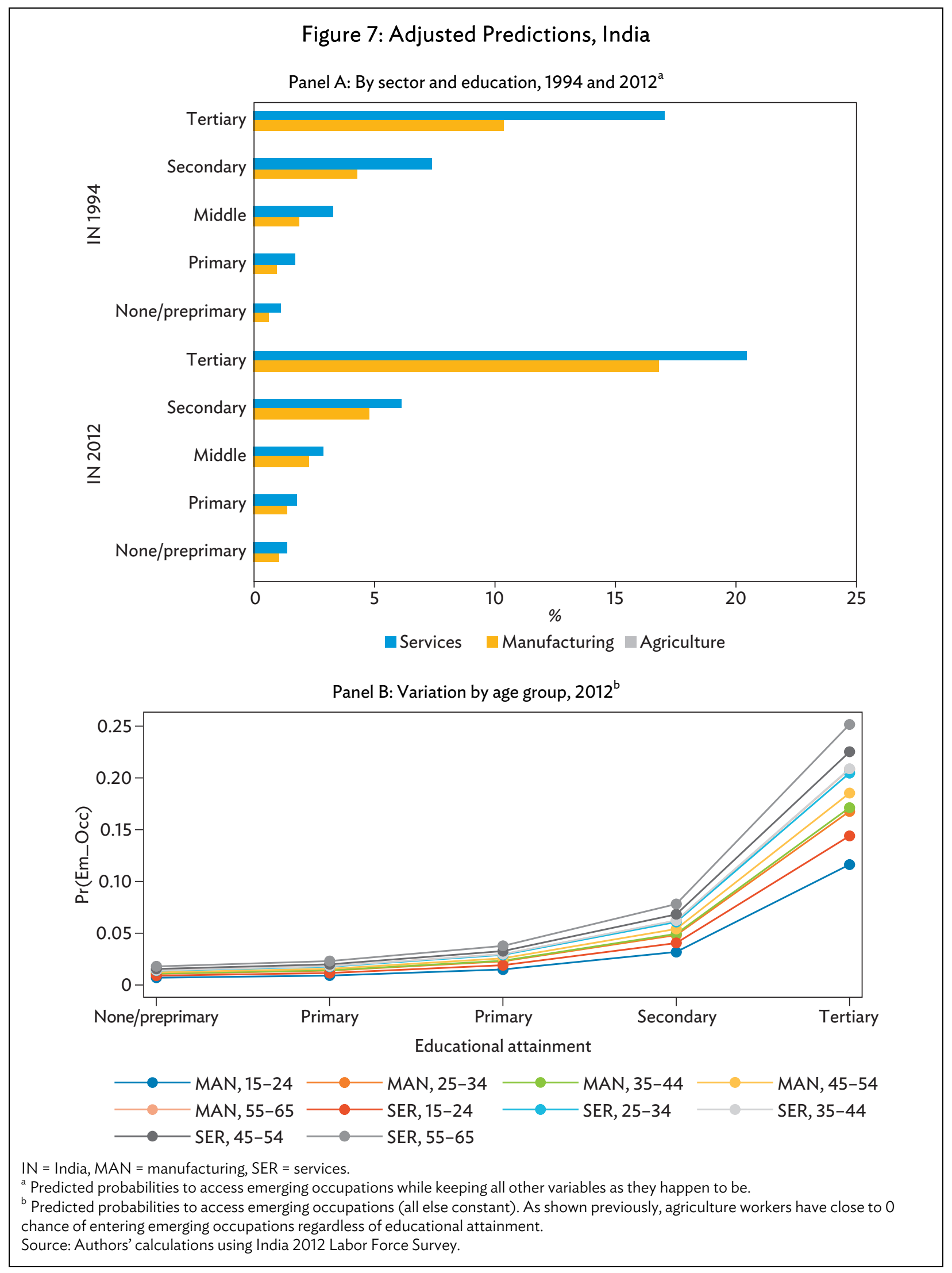


Figure 8 shows the adjusted predictions in the case of Viet Nam 2009 and 2015. In both cases, the predicted probabilities of accessing emerging occupations, $y=1$, is highest for tertiary-educated workers in the service sectors at 6\%-7\%. Once again, as in India, probabilities of success decrease as a worker moves from services to manufacturing to agriculture, and any worker in the agriculture sector has zero chance of success regardless of his or her educational attainment. Although predicted probabilities of success in Viet Nam are generally lower than those reported in India, it is nevertheless rather interesting that workers with secondary, primary, and none to preprimary educational attainments have more or less equally low chances of $y=1$ across all three sectors. Indeed, these findings are not in line with the notion that access to newer types of work would increase with one's educational attainment.

Panel $B$ shows how adjusted predictions by education and sector vary across age groups in the case of Viet Nam 2015. Unlike the findings in India 2012, younger tertiary-educated workers in the service sector, particularly those belonging to the 25-34 age group, have the highest chances of accessing emerging occupations, followed closely by 35-44 year olds (second), and 55-65 year olds (third) and 45-54 year olds (fourth). However, unlike the case of India, only approximately 47\% of emerging occupation workers in Viet Nam (both years) are emerging occupation workers that fall under professional or associate professional categories (high skilled). Moreover, it can be argued that findings in panels $A$ and $B$ may not be that surprising considering that emerging occupation workers in Viet Nam are largely concentrated in sales occupations. As seen previously, 50\% of all emerging occupation workers are categorized as either sales, marketing, and public relations professionals (high skilled) or other sales workers (low skilled), of which 26\% in 2015 and 33\% in 2009 belong to the latter type of sales occupation group. ${ }^{46}$ Jobs held by other sales workers often do not require attendance of formal higher education, training, or advanced literacy and numeracy skills. Therefore, access to this type of occupation may be easier for workers with lower educational attainments or younger workers who are at the earlier stages of their career and who have not yet accumulated much work experience. ${ }^{47}$

46 Examples of job titles falling under sales, marketing, and public relations professionals include advertising and marketing professionals, and public relations professionals. Examples of job titles falling under other sales workers are sales demonstrators, door-to-door salespersons, food service attendants.

47 Indeed, when looking at the 2015 microdata, 50\% of sales, marketing, and public relations professionals, are aged 25-34 and $99 \%$ have some form of tertiary education, whereas 30\% of other sales workers belong to the 25-34 age group and $51 \%$ have secondary education; only $16 \%$ have tertiary education. 
Figure 8: Adjusted Predictions, Viet Nam

Panel A: By sector and education, 2009 and $2015^{a}$

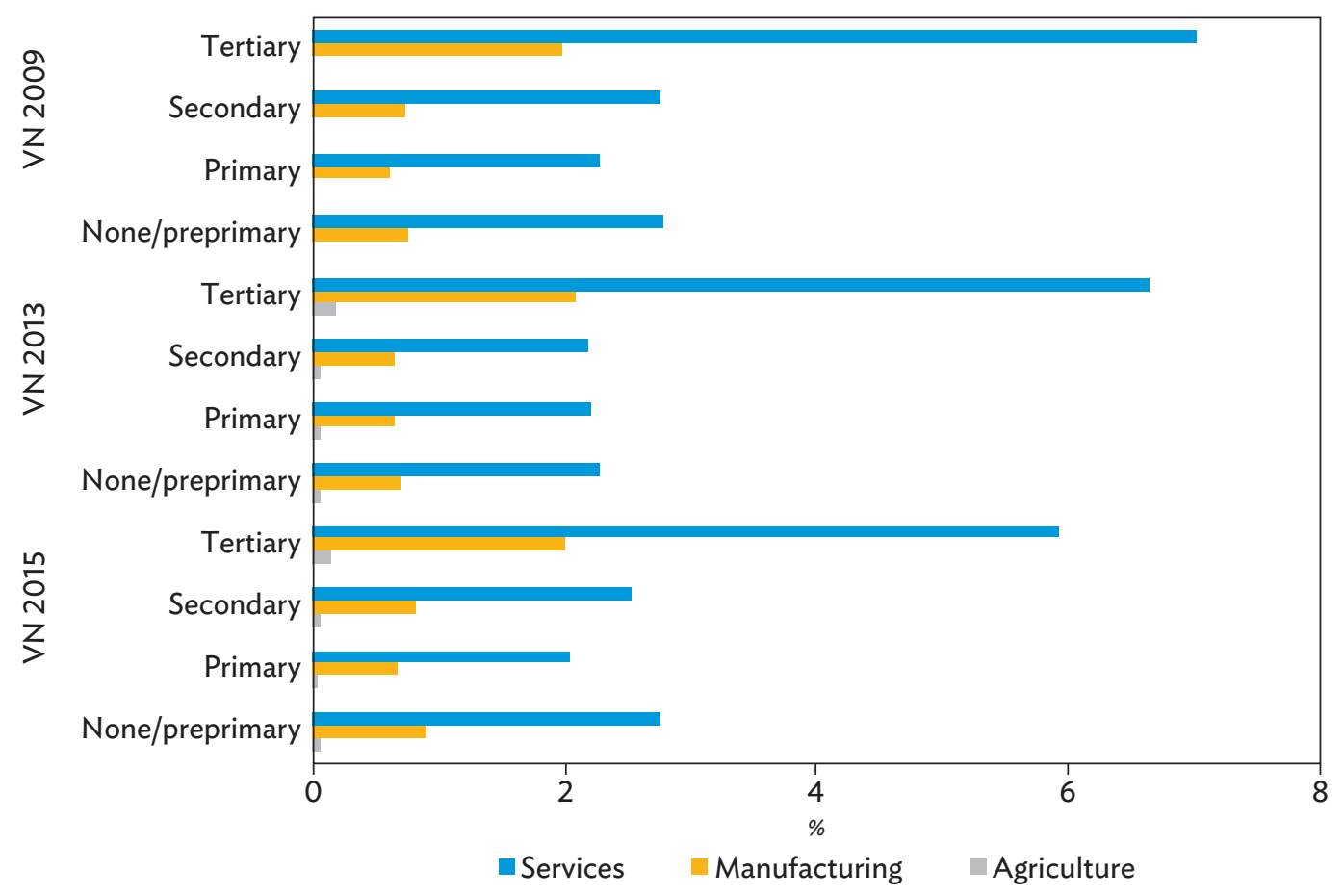

Panel B: Variation by age group, Viet Nam $2015^{\mathrm{b}}$

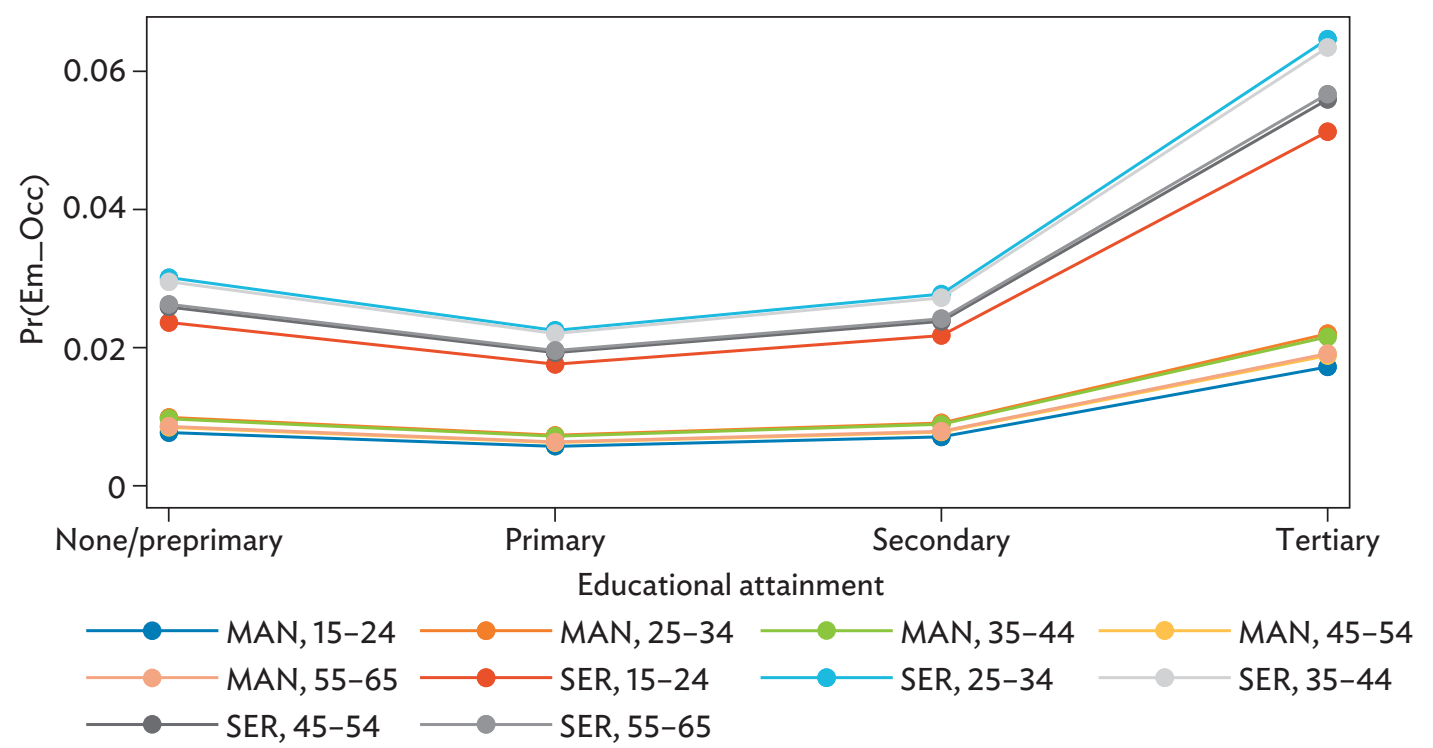

MAN = manufacturing, $\mathrm{SER}=$ services, $\mathrm{VN}=$ Viet Nam.

${ }^{a}$ Predicted probabilities to access emerging occupation (all else constant). Predicted probabilities for agricultural workers in Viet Nam 2009 were not significant.

${ }^{b}$ As shown previously, agriculture workers have close to zero chance of entering emerging occupations regardless of educational attainment. Source: Authors' calculations using 2009 and 2015 Viet Nam Labor Force Surveys. 


\section{CONCLUDING REMARKS}

In this paper, we empirically study new types of work by identifying new job titles and emerging occupations in developing Asia. By comparing successive lists of occupation classifications in India, Malaysia, the Philippines, and Viet Nam, we find that most new types of work are high-skilled and primarily ICT-related positions. Upon using the microdata of Viet Nam, we find that emerging occupations pay higher wages than nonemerging occupations, although employment in emerging occupations is very low. Further, when using logit models to predict chances of access to emerging occupations given workers' characteristics, the probabilities of success are greater for workers who are male, higher educated, and urban based, and in the service sectors (relative to their respective base categories). Adjusted predictions further show that probabilities of success among tertiary-educated workers in the service sector can vary greatly across age groups.

One contribution of this paper is that we explore new types of work in developing Asia by investigating how and to what extent various workers' characteristics can influence one's chances of accessing emerging occupations. In doing so, it also contributes to the literature on technology and aging, especially considering Asia's aging population, in that older workers may not necessarily need to fear the displacement effects of technology, especially if they have some form of tertiary education. Another key contribution is that it highlights not only the importance of intersectoral reallocations of labor from agriculture to nonagriculture sectors, but it also stresses the importance of knowing which types of occupation groups within the nonagriculture sectors can potentially yield higher returns to transitioning workers.

New technologies and the massive and rapid changes that developing Asia is going through are inevitably altering the world of work. While the finding that most new types of work identified in the analysis are ICT-related positions, thus strengthening the need to push greater digital literacy, what is also equally important is to address the data limitations that constrain a better understanding of the emergence of and demand for new types of work. For instance, while NCOs are broadly patterned after the ILO's ISCO, they should be overhauled and constructed to be as exhaustive as possible in terms of job titles. This would allow researchers to have the possibility of analyzing employment trends in new jobs as opposed to only broad occupation groups. Research on high-tech firms or industries can also be done to obtain a better understanding of the types of jobs or roles that companies find to be the most difficult to fill. This will also help policy makers enact strategies that would help workers, especially those who face the highest risks of displacement, to assimilate into new types of work. Nevertheless, extending the analysis to include more countries in developing Asia as well as identifying specific types of skill sets deemed important in emerging occupations are promising avenues for future research on new types of work. 


\section{APPENDIXES}

\section{Appendix 1: Maximum Likelihood Estimation}

To estimate the parameters of interest in our models, we rely on maximum likelihood estimation. As in Söderbom (2009), the maximum likelihood estimate of $\beta$ is the particular vector $\hat{B}^{M L}$ that gives us the greatest likelihood of observing the sample, $\left\{y_{1}, y_{2}, \ldots . y_{N}\right\}$, conditional on the explanatory variables $\boldsymbol{x}$.

By assumption, the probability of observing $y_{i}=1$ is $G(\boldsymbol{x} \boldsymbol{\beta})$, while the probability of observing $y_{i}=0$ is $1-G(\boldsymbol{x} \boldsymbol{\beta})$. The probability of observing the entire sample is thus

$$
L(y \mid x ; \boldsymbol{\beta})=\prod_{i \in k} G\left(\boldsymbol{x}_{i} \boldsymbol{\beta}\right) \prod_{i \in j}\left[1-G\left(\boldsymbol{x}_{i} \boldsymbol{\beta}\right)\right],
$$

where $k$ refers to the observations for which $y=1$ and $j$ to the observations for which $y=0$.

We can rewrite this as

$$
\mathcal{L}(y \mid x ; \beta)=\prod_{i=1}^{N} G\left(\boldsymbol{x}_{i} \boldsymbol{\beta}\right)^{y_{i}}\left[1-G\left(\boldsymbol{x}_{i} \boldsymbol{\beta}\right)\right]^{\left(1-y_{i}\right)} .
$$

The log likelihood for the sample is thus

$$
\ln \mathcal{L}(y \mid \boldsymbol{x} ; \boldsymbol{\beta})=\sum_{i=1}^{N}\left\{y_{i} \ln G\left(\boldsymbol{x}_{i} \boldsymbol{\beta}\right)+\left(1-y_{i}\right) \ln \left[1-G\left(\boldsymbol{x}_{i} \boldsymbol{\beta}\right)\right]\right\}
$$

The maximum likelihood estimation of $\beta$ maximizes this log likelihood function.

As $G$ is the logistic cumulative distribution function, we obtain the logit likelihood:

$$
\begin{gathered}
\ln \mathcal{L}(y \mid x ; \beta)=\sum_{i=1}^{N}\left\{y_{i} \ln \Lambda\left(\boldsymbol{x}_{i} \boldsymbol{\beta}\right)+\left(1-y_{i}\right) \ln \left[1-\Lambda\left(\boldsymbol{x}_{i} \boldsymbol{\beta}\right)\right]\right\} \\
\ln \mathcal{L}(y \mid \boldsymbol{x} ; \boldsymbol{\beta})=\sum_{i=1}^{N}\left\{y_{i} \ln \left(\frac{\exp \left(\boldsymbol{x}_{i} \boldsymbol{\beta}\right)}{1+\exp \left(\boldsymbol{x}_{i} \boldsymbol{\beta}\right)}\right)+\left(1-y_{i}\right) \ln \left(\frac{1}{1+\exp \left(\boldsymbol{x}_{i} \boldsymbol{\beta}\right)}\right)\right\},
\end{gathered}
$$

which simplifies to

$$
\ln \mathcal{L}(y \mid \boldsymbol{x} ; \boldsymbol{\beta})=\sum_{i=1}^{N}\left\{y_{i}\left[\boldsymbol{x}_{i} \boldsymbol{\beta}-\ln \left(1+\exp \left(\boldsymbol{x}_{i} \boldsymbol{\beta}\right)\right)\right]-\left(1-y_{i}\right) \ln \left(1+\exp \left(\boldsymbol{x}_{i} \boldsymbol{\beta}\right)\right)\right\} .
$$




\section{Appendix 2}

Table A2: Variable List

\begin{tabular}{|c|c|}
\hline Variable & Categories \\
\hline \multirow[t]{3}{*}{ Sector } & 1 - Agriculture \\
\hline & 2 - Manufacturing \\
\hline & 3 - Services \\
\hline \multirow[t]{5}{*}{ Education* } & 1 - None/preprimary \\
\hline & 2 - Primary \\
\hline & 3 -Middle \\
\hline & 4 - Secondary \\
\hline & 5 - Tertiary \\
\hline \multirow[t]{2}{*}{ Gender } & 0 - Female \\
\hline & 1 - Male \\
\hline \multirow[t]{5}{*}{ Age group } & $1-15-24$ \\
\hline & $2-25-34$ \\
\hline & $3-35-44$ \\
\hline & $4-45-54$ \\
\hline & $5-55-65$ \\
\hline \multirow[t]{2}{*}{ Location } & 0 - Rural \\
\hline & $1-$ Urban \\
\hline \multirow[t]{3}{*}{ Marital status } & 1 - Single \\
\hline & 2 - Married \\
\hline & 3 - Separated/widowed \\
\hline \multicolumn{2}{|c|}{ Work experience } \\
\hline \multicolumn{2}{|c|}{$\begin{array}{l}{ }^{*} \text { The five education categories refer to India only. Viet Nam has no } \\
\text { middle educational attainment, thus, its education variable is categorized as: } \\
1 \text { - None/preprimary, } 2 \text { - Primary, } 3 \text { - Secondary, and } 4 \text { - Tertiary. } \\
\text { Notes: The sector variable follows the 1-digit International Standard Industrial } \\
\text { Classification of All Economic Activities (ISIC) classification; manufacturing } \\
\text { includes mining, public utilities, and construction; and services includes trade } \\
\text { services, transport and communication services, business services, government } \\
\text { services, and personal services. } \\
\text { Source: Authors. }\end{array}$} \\
\hline
\end{tabular}




\section{Appendix 3: New Job Titles, National Classification of Occupations}

Table A3.1: India 2004

\begin{tabular}{|c|c|}
\hline Job Title Code & Job Title \\
\hline 1221.24 & Manager, aerial planting and cultivation \\
\hline 2113.8 & Chemist, forensic science \\
\hline 2114.15 & Geologist, petroleum \\
\hline 2119.1 & Metrologist \\
\hline 2122.3 & Operation research analyst \\
\hline 2131.2 & Data communication analyst \\
\hline 2132.2 & Software engineer \\
\hline 2132.3 & Programmer analyst \\
\hline 2132.4 & Programmer, engineering and scientific \\
\hline 2132.5 & System programmer \\
\hline 2139.1 & Quality assurance analyst(computer) \\
\hline 2139.2 & Data base design analyst \\
\hline 2139.3 & Data base administrator \\
\hline 2139.4 & Computer system hardware analyst \\
\hline 2144.7 & Electro-optical engineer \\
\hline 2149.05 & Solar energy system designer \\
\hline 2149.22 & Radiation protection engineer \\
\hline 2149.77 & Packaging engineer \\
\hline 2149.88 & Engineer, pollution control \\
\hline 2211.27 & Environment scientist \\
\hline 2212.2 & Chemist, food \\
\hline 2225.6 & Paediatric dentist \\
\hline 2310.18 & University and college teacher, management subjects \\
\hline 2310.48 & University and college teacher, information technology \\
\hline 2441.2 & Energy economist \\
\hline 2442.25 & Clinical sociologist \\
\hline 2445.3 & Psychologist, engineering \\
\hline 2445.5 & Psychologist, social \\
\hline 2446.85 & Counsellor, marriage and family \\
\hline 2451.47 & Caption writer \\
\hline 2452.7 & Multimedia artist and animator \\
\hline 2452.8 & Web designer \\
\hline 3111.35 & Chemical radiation technician \\
\hline 3113.3 & Energy auditor \\
\hline
\end{tabular}


Table A3.1 continued

\begin{tabular}{|c|c|}
\hline Job Title Code & Job Title \\
\hline 3116.6 & Chemist, water purification \\
\hline 3119.2 & Forensic science technician \\
\hline 3121.3 & Computer security specialist \\
\hline 3121.35 & Data recovery planner \\
\hline 3121.5 & Desk top publishing operator \\
\hline 3133.2 & Bio-medical equipment technician \\
\hline 3139.1 & Laser technician \\
\hline 3211.5 & Dialysis technician \\
\hline 3212.1 & Agricultural engineering technician \\
\hline 3214.2 & Environment compliance inspector \\
\hline 3214.3 & Environmental engineering technician \\
\hline 3229.4 & Orthotist and prosthetist \\
\hline 3229.5 & Orientation and mobility instructor \\
\hline 3412.2 & Insurance surveyor \\
\hline 3415.85 & Customer service analyst \\
\hline 3429.1 & Call center executive \\
\hline 3460.2 & Equal opportunity officer \\
\hline 3471.7 & Graphic designer \\
\hline 7243.45 & Cable television installer \\
\hline 8172.1 & Industrial robot operator \\
\hline
\end{tabular}

Note: Based on comparisons of 1968 and 2004 National Classification of Occupations. Source: Authors' calculations.

Table A3.2: India 2005

\begin{tabular}{ll}
\hline Job Title Code & \multicolumn{1}{c}{ Job Title } \\
\hline 2113.0621 & Lab chemist - finished product testing \\
2113.0622 & Lab chemist - incoming raw material testing \\
2113.0623 & Lab chemist - compound testing - batch release \\
2113.0624 & Lab chemist - cured compound testing \\
2120.0501 & Associate - analytics \\
2144.0103 & Process tryout technician \\
2144.0104 & Process validation executive \\
2144.0106 & Manager - product lifecycle management \\
2151.0403 & Light emitting diode (LED) light design engineer \\
2151.0404 & LED light design validation engineer \\
2151.0601 & System analyst (printed circuit board [PCB] design) \\
\hline &
\end{tabular}


Table A3.2 continued

\begin{tabular}{|c|c|}
\hline Job Title Code & Job Title \\
\hline 2151.0602 & Systems designer (PCB design) \\
\hline 2153.0101 & $\begin{array}{l}\text { Telecom terminal equipment application developer } \\
\text { (android) }\end{array}$ \\
\hline 2153.0102 & Telecom terminal equipment application (native applications) \\
\hline 2153.0601 & Core engineer \\
\hline 2166.0203 & Rigging artist \\
\hline 2166.0204 & Texturing artist \\
\hline 2166.0205 & Animation director \\
\hline 2166.0206 & Character designer \\
\hline 2166.0207 & Cleanup artist \\
\hline 2166.021 & Rendering artist \\
\hline 2166.0211 & Visual effects editor \\
\hline 2166.0212 & Roto artist \\
\hline 2166.0401 & Designer (computer-aided design) \\
\hline 2166.0511 & Color key artist \\
\hline 7223.5001 & $\begin{array}{l}\text { Machining technician/Computer numerical control (CNC) } \\
\text { operator }\end{array}$ \\
\hline 7223.5002 & CNC operator - machining technician \\
\hline 7223.5003 & CNC operator - machinist \\
\hline 7223.5004 & CNC operator - vertical machining center \\
\hline 7223.5005 & CNC setter-cum-operator - vertical machining center \\
\hline 7223.6001 & CNC setter-cum-operator - turning \\
\hline 7223.6002 & CNC operator - turning \\
\hline 7223.6003 & CNC programmer \\
\hline 7311.1002 & Calibration engineer \\
\hline 7412.0101 & Automation specialist \\
\hline 7421.1401 & Solar panel installation technician \\
\hline 7421.1402 & Solar photo voltaic system installation technician \\
\hline 7421.1403 & PV system installation engineer \\
\hline 7422.0201 & Fault management engineer \\
\hline 7422.0202 & Grass root telecom provider (GRTP) \\
\hline 7422.0801 & Optical fiber technician \\
\hline 7422.0802 & Optical fiber splicer \\
\hline 7422.1201 & Set-top box installer/service technician \\
\hline 7422.1202 & DTH set-top box installer and service technician \\
\hline 7422.1203 & DAS set-top box installer and service technician \\
\hline 7422.2301 & Smartphones repair technician \\
\hline 7532.0901 & Garment cutter (computer-aided manufacturing [CAM]) \\
\hline
\end{tabular}


Table A3.2 continued

\begin{tabular}{|c|c|}
\hline Job Title Code & Job Title \\
\hline 7532.0902 & $\begin{array}{l}\text { Advance pattern maker, garment (computer-aided design } \\
[C A D] / C A M)\end{array}$ \\
\hline 7543.0801 & Functional tester \\
\hline 7543.0802 & Performance tester \\
\hline 7543.0803 & Reliability tester \\
\hline 7543.0804 & Safety testing technician \\
\hline 8153.0701 & Framer - computerized embroidery machine \\
\hline 8189.0301 & CAM machine operator \\
\hline 8189.0401 & Laser sawing machine operator \\
\hline 8212.1607 & Box-building assembly technician \\
\hline 8212.1701 & Wire bonding operator \\
\hline 8212.1702 & Die bonding operator \\
\hline 8212.2601 & Electronic sub-assembly technician \\
\hline 9611.0201 & E-waste collector \\
\hline 2240.99 & Paramedical practitioners, other \\
\hline 2264.0401 & Sports masseur \\
\hline 2265.0201 & Dietician assistant \\
\hline 3211.0801 & Cardiac care technician \\
\hline 3212.0601 & Phlebotomy technician \\
\hline 3253.0101 & Diabetes educator \\
\hline 3256.0101 & Refractionist \\
\hline 2356.0301 & Master trainer for junior software developer \\
\hline 2411.0101 & Associate - transactional finance and accounting \\
\hline 2411.0201 & Associate - finance and accounting complex \\
\hline 2432.0201 & Digital marketing/social media manager \\
\hline 2433.0501 & Sales executive - solar electronics \\
\hline 2511.0101 & Deployment engineer \\
\hline 2511.0102 & Engineer - software transition \\
\hline 2512.0205 & Junior software developer \\
\hline 2512.0206 & Engineer trainee - IT services \\
\hline 2512.0207 & Engineer trainee - engineering analysis \\
\hline 2512.0401 & Field programmable gate array (FPGA) design engineer \\
\hline 2512.0501 & Embedded software engineer \\
\hline 2521.0202 & Junior data associate \\
\hline 2522.0201 & Security analyst \\
\hline 2643.0401 & Language translator - software products \\
\hline 2643.0402 & Language translator - IT services \\
\hline
\end{tabular}


Table A3.2 continued

\begin{tabular}{|c|c|}
\hline Job Title Code & Job Title \\
\hline 3113.0701 & Customer inspection technician \\
\hline 3113.1001 & LED luminaries testing and measurement \\
\hline 3113.1002 & LED light repair technician \\
\hline 3114.0601 & BSS support engineer \\
\hline 3114.0801 & ICT engineer \\
\hline 3114.0802 & ICT technician \\
\hline 3114.0804 & Broadband technician \\
\hline 3114.0902 & $\begin{array}{l}\text { Installation engineer installation engineer - synchronous } \\
\text { digital hierarchy (SDH) and dense wavelength division } \\
\text { multiplexing (DWDM) }\end{array}$ \\
\hline 3114.1301 & Network management engineer \\
\hline 3115.0301 & Executive, proto manufacturing \\
\hline 3115.0401 & Method study executive \\
\hline 3142.0101 & Micro irrigation technician \\
\hline 3142.0201 & Bare foot technician (BFT) \\
\hline 3322.1702 & Marketing and social media manager \\
\hline 3323.0501 & Purchase executive - solar \\
\hline 3511.0101 & Domestic biometric data operator \\
\hline 3512.0101 & Domestic it helpdesk attendant \\
\hline 3512.0202 & Associate-desktop publishing (DTP) \\
\hline 3512.0401 & Disk duplicator \\
\hline 3512.0501 & IT coordinator in school \\
\hline 3512.0601 & Associate - clinical data management \\
\hline 3512.0702 & Associate - medical transcription \\
\hline 4222.0101 & Technical support executive - nonvoice \\
\hline 4222.0102 & Technical support executive - voice \\
\hline 5243.0502 & Sales executive (broadband) \\
\hline 5244.0101 & Customer relationship management (CRM) domestic voice \\
\hline 5244.0201 & CRM domestic nonvoice \\
\hline 5244.0202 & Associate customer care (nonvoice) \\
\hline 5244.0302 & Remote helpdesk technician \\
\hline 5244.0303 & Customer care executive (call center) \\
\hline 5414.0121 & Closed-circuit television (CCTV) supervisor \\
\hline
\end{tabular}

$\mathrm{CAD}=$ compuer-aided design, $\mathrm{DAS}$ = digital addressable system, $\mathrm{DTH}$ = direct-to-home. Note: Based on comparisons of 2004 and 2015 National Classification of Occupations. Source: Authors' calculations. 
Table A3.3: Malaysia 2008

\begin{tabular}{|c|c|}
\hline Job Title Code & Job Title \\
\hline 21125 & Agrometeorologist \\
\hline 21127 & Meteorologist, environmental \\
\hline 21128 & $\begin{array}{l}\text { Meteorologist, numerical weather prediction (NWP) } \\
\text { Modeling }\end{array}$ \\
\hline 21495 & Engineering executive, store \\
\hline 24122 & Adviser, e-commerce \\
\hline 24333 & Sales representatives, active implantable devices \\
\hline 24334 & Sales representatives, anaesthetic and respiratory devices \\
\hline 24341 & $\begin{array}{l}\text { Sales representatives, information and communication } \\
\text { technology (ICT) }\end{array}$ \\
\hline 24342 & Sales representatives, computer \\
\hline 25112 & Analyst, business (information technology [IT]) \\
\hline 25122 & Analyst, programmer \\
\hline 25132 & Architect, website \\
\hline 25133 & Programmer, animation/computer games/multimedia \\
\hline 25192 & Tester, software \\
\hline 25193 & Tester, systems \\
\hline 25232 & Administrator/Netapps \\
\hline 25291 & Security specialist, ICT \\
\hline 31221 & Supervisor, compounding \\
\hline 33565 & Officer, The People's Volunteer Corps (RELA) \\
\hline 35113 & Technician, information systems \\
\hline 35141 & Technician, website \\
\hline 41102 & Clerk, management information systems \\
\hline 42224 & Telemarketer, salesperson \\
\hline 42225 & Clerk, call center \\
\hline 74223 & Worker, IT support \\
\hline 75131 & Entrepreneur, cheese \\
\hline
\end{tabular}

Note: Based on comparisons of 1998 and 2008 National Classification of Occupations. Source: Authors' calculations. 
Table A3.4: Philippines 2012

\begin{tabular}{|c|c|}
\hline Job Title Code & Job Title \\
\hline 1212 & Industrial zone manager \\
\hline 1213 & Corporate compliance manager \\
\hline 1213 & Policy manager \\
\hline 1322 & Equipment manager (mining) \\
\hline 1322 & Exploration manager \\
\hline 2133 & Environment adviser \\
\hline 2143 & Environment analyst \\
\hline 2143 & Environment remediation specialist \\
\hline 2166 & Computer games designer \\
\hline 2166 & Digital artist \\
\hline 2166 & Multimedia designer \\
\hline 2166 & Publication designer \\
\hline 2166 & Web designer \\
\hline 2519 & AutoCAD designer \\
\hline 2519 & Quality assurance analyst (computer) \\
\hline 2519 & Software tester \\
\hline 2519 & Systems tester \\
\hline 2529 & Digital forensic specialist \\
\hline 2529 & Security specialist (information and communication technology) \\
\hline 3259 & Occupational therapy technician \\
\hline 3341 & Data entry supervisor \\
\hline 3513 & Computer network technician \\
\hline 3513 & Network support technician \\
\hline 4416 & Employee data management practitioner \\
\hline 5329 & Medical imaging assistant \\
\hline 7322 & Digital press operator \\
\hline 7322 & Wallpaper printer \\
\hline 7413 & Transmission technician \\
\hline 7421 & Automated teller machines mechanic \\
\hline 7421 & Avionics technician \\
\hline 7421 & Electric typewriter technician \\
\hline 7421 & Electronic equipment servicer \\
\hline 7421 & Office equipment technician \\
\hline 7421 & Reprographic equipment technician \\
\hline 7421 & $\begin{array}{l}\text { Video electronics (vertical helical scan [VHS], video compact disc [VCD], } \\
\text { digital versatile disc [DVD]) service/repairman }\end{array}$ \\
\hline 7421 & Adding machine technician \\
\hline 8142 & Optic fiber drawer \\
\hline 8159 & Radioactive materials chemical processer \\
\hline
\end{tabular}

Notes: The new job titles above do not have unique codes, but have unique titles. Based on comparisons of 1990 and 2012 National Classification of Occupations.

Source: Authors' calculations. 


\section{Table A3.5: Viet Nam 2008}

\begin{tabular}{ll}
\hline Job Title Code & Job Title \\
\hline 3514 & Web technicians \\
2356 & Information technology trainers \\
2521 & Database designers and administrators \\
5244 & Contact center salespersons \\
2513 & Web and multimedia developers \\
2133 & Environmental protection professionals \\
2522 & Systems administrators \\
2514 & Applications programmers \\
4222 & Contact center information clerks \\
2166 & Graphic and multimedia designers \\
3512 & Information and communication technology (ICT) user support \\
3511 & technicians \\
2512 & Information and communications technology operations technicians \\
2434 & Software developers \\
2523 & Information and communications technology sales professionals \\
7422 & Computer network professionals \\
\hline
\end{tabular}

Note: Based on comparisons of 1998 and 2008 National Classification of Occupations.

Source: Authors' calculations. 


\section{Appendix 4: Emerging Occupations}

Table A4.1: India 1968-2004

\begin{tabular}{|c|c|}
\hline $\begin{array}{l}\text { Occupation } \\
\text { Group Code }\end{array}$ & Occupation Group Title \\
\hline 122 & Production and operations department managers \\
\hline 211 & Physicists, chemists, and related professionals \\
\hline 212 & Mathematicians, statisticians, and related professionals \\
\hline 213 & Computing professionals \\
\hline 214 & Architects, engineers, and related professionals \\
\hline 221 & Life science professionals \\
\hline 222 & Health professionals (except nursing) \\
\hline 231 & College, university, and higher education teaching professionals \\
\hline 244 & Social science and related professionals \\
\hline 245 & Writers and creative or performing artists \\
\hline 311 & Physical and engineering science technicians \\
\hline 312 & Computer associate professionals \\
\hline 313 & Optical and electronic equipment operators \\
\hline 321 & $\begin{array}{l}\text { Life science technicians and related health associate } \\
\text { professionals }\end{array}$ \\
\hline 322 & Modern health associate professionals (except nursing) \\
\hline 341 & Finance and sales associate professionals \\
\hline 342 & Business services agents and trade brokers \\
\hline 346 & Social work associate professionals \\
\hline 347 & Artistic, entertainment, and sports associate professionals \\
\hline 724 & Electrical and electronic equipment mechanics and fitters \\
\hline 817 & Automated assembly line and industrial robot operators \\
\hline
\end{tabular}

Note: Based on comparisons of 1968 and 2004 National Classification of Occupations. Source: Authors' calculations. 
Table A4.2: India 2004-2015

\begin{tabular}{|c|c|}
\hline $\begin{array}{l}\text { Occupation } \\
\text { Group Code }\end{array}$ & Occupation Group Title \\
\hline 211 & Physical and earth science professionals \\
\hline 212 & Mathematicians, actuaries, and statisticians \\
\hline 214 & Engineering professionals (excluding electrotechnology) \\
\hline 215 & Electrotechnology engineers \\
\hline 216 & Architects, planners, surveyors, and designers \\
\hline 224 & Paramedical practitioners \\
\hline 226 & Other health professionals \\
\hline 235 & Other teaching professionals \\
\hline 241 & Finance professionals \\
\hline 243 & Sales, marketing, and public relations professionals \\
\hline 251 & Software and application developers, and analysts \\
\hline 252 & Database and network professionals \\
\hline 264 & Authors, journalists, and linguists \\
\hline 311 & Physical and engineering science technicians \\
\hline 314 & Life science technicians and related associate professionals \\
\hline 321 & Medical and pharmaceutical technicians \\
\hline 325 & Other health associate professionals \\
\hline 332 & Sales and purchasing agents and brokers \\
\hline 351 & $\begin{array}{l}\text { Information and communication technology (ICT) operations } \\
\text { and user support technicians }\end{array}$ \\
\hline 422 & Client information workers \\
\hline 524 & Other sales workers \\
\hline 541 & Protective service workers \\
\hline 722 & Blacksmiths, tool makers, and related trades workers \\
\hline 731 & Handicraft workers \\
\hline 741 & Electrical equipment installers and repairers \\
\hline 742 & Electronics and telecommunication installers and repairers \\
\hline 753 & Garment and related trades workers \\
\hline 754 & Other craft and related workers \\
\hline 815 & Textile, fur, and leather products machine \\
\hline 818 & Other stationary plant and machine operators \\
\hline 821 & Assemblers \\
\hline 961 & Refuse workers \\
\hline
\end{tabular}

Note: Based on comparisons of 2004 and 2015 National Classification of Occupations. Source: Authors' calculations. 
Table A4.3: Malaysia 1998-2008

\begin{tabular}{ll}
$\begin{array}{l}\text { Occupation } \\
\text { Group Code }\end{array}$ & \\
\hline 211 & Occupation Group Title \\
214 & Engineering professionals (excluding electrotechnology) \\
241 & Finance professionals \\
243 & Sales, marketing, and public relations professionals \\
251 & Software and applications developers and analysts \\
252 & Database and network professionals \\
312 & Mining, manufacturing, and construction supervisors \\
335 & Regulatory government associate professionals \\
351 & Information and communication technology operations and user support technician \\
411 & General office clerks \\
422 & Client information workers \\
742 & Electronics and telecommunications installers and repairers \\
751 & Food processing and related workers
\end{tabular}

Note: Based on comparisons of 1998 and 2008 National Classification of Occupations.

Source: Authors' calculations.

Table A4.4: Philippines 1990-2012

\begin{tabular}{ll}
\hline $\begin{array}{l}\text { Occupation } \\
\text { Group Code }\end{array}$ & \multicolumn{1}{c}{ Occupation Group Title } \\
\hline 121 & Business services and administration managers \\
132 & Manufacturing, mining, construction, and distribution managers \\
213 & Life science professionals \\
214 & Engineering professionals (excluding electrotechnology) \\
216 & Architects, planners, surveyors, and designers \\
251 & Software and applications developers and analysts \\
252 & Database and network professionals \\
325 & Other health associate professionals \\
334 & Administrative and specialized secretaries \\
351 & Information and communication technology operations and user support technicians \\
441 & Other clerical support workers \\
532 & Personal care workers in health services \\
732 & Printing trades workers \\
741 & Electrical equipment installers and repairers \\
742 & Electronics and telecommunications installers and repairers \\
814 & Rubber, plastic, and paper products machine operators \\
815 & Textile, fur, and leather products machine operators \\
\hline
\end{tabular}

Note: Based on comparisons of 1990 and 2012 National Classification of Occupations. Source: Authors' calculations. 
Table A4.5: Viet Nam 1998-2008

\begin{tabular}{ll}
\hline $\begin{array}{l}\text { Occupation } \\
\text { Group Code }\end{array}$ & \multicolumn{1}{c}{ Occupation Group Title } \\
\hline 213 & Life science professionals \\
216 & Architects, planners, surveyors, and designers \\
235 & Teaching professionals not elsewhere classified \\
243 & Sales, marketing, and public relations professionals \\
251 & Software and applications developers and analysts \\
252 & Database and network professionals \\
351 & Information and communication technology operations and user support technicians \\
422 & Client information workers \\
524 & Other sales workers \\
742 & Electronics and telecommunications installers and repairers \\
\hline
\end{tabular}

Note: Based on comparisons of 1998 and 2008 National Classification of Occupations. Source: Authors' calculations. 


\section{Appendix 5}

Figure A5: Wages of Job Titleholders (Wageworkers) within Emerging Occupations, Viet Nam 2015

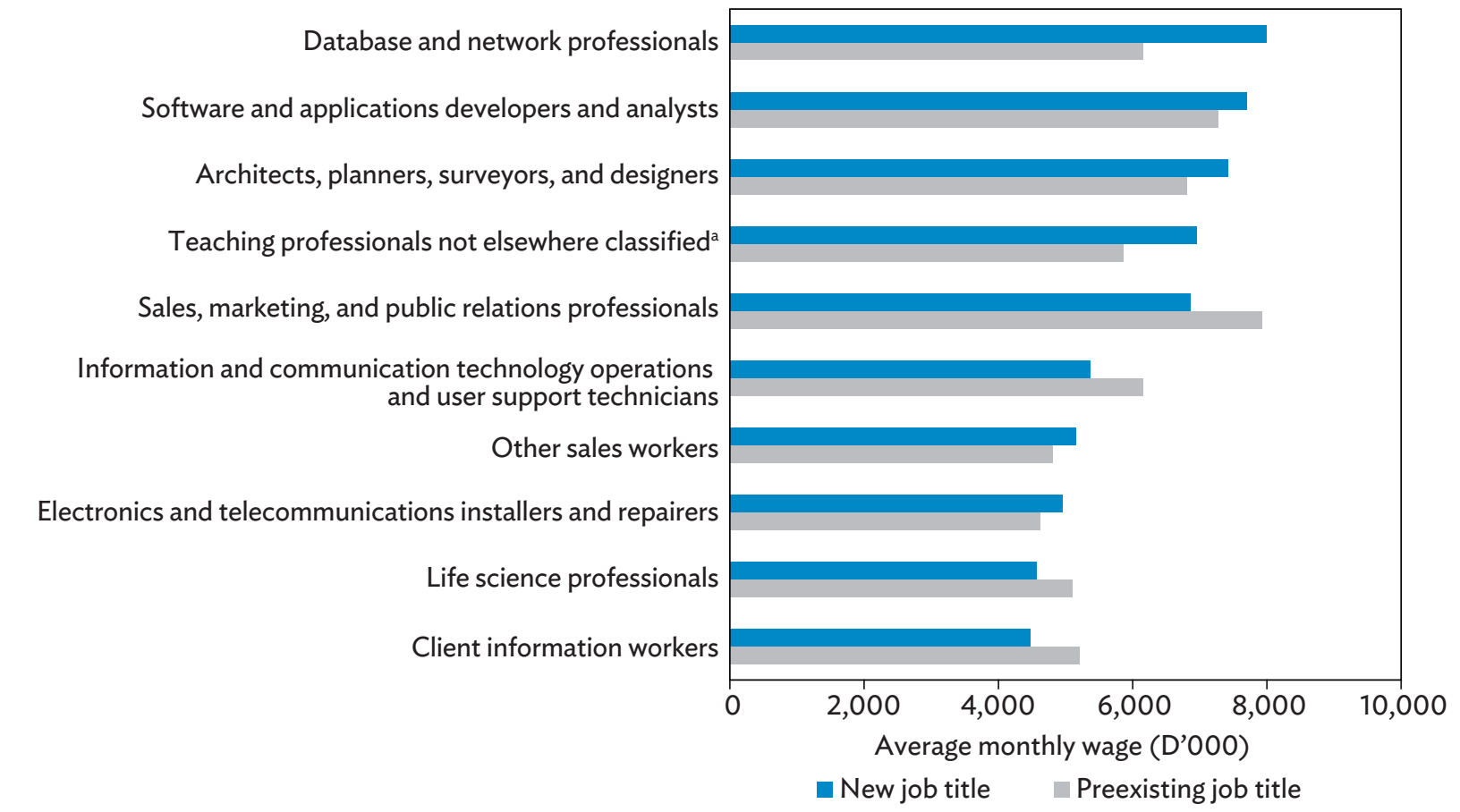

${ }^{\text {a }}$ For example, information technology trainers.

Source: Authors' calculations using Viet Nam 2015 Labor Force Survey. 


\section{Appendix 6}

Figure A6: Average Monthly Wages of Information and Communication Technology Professional Wageworkers, Viet Nam 2015

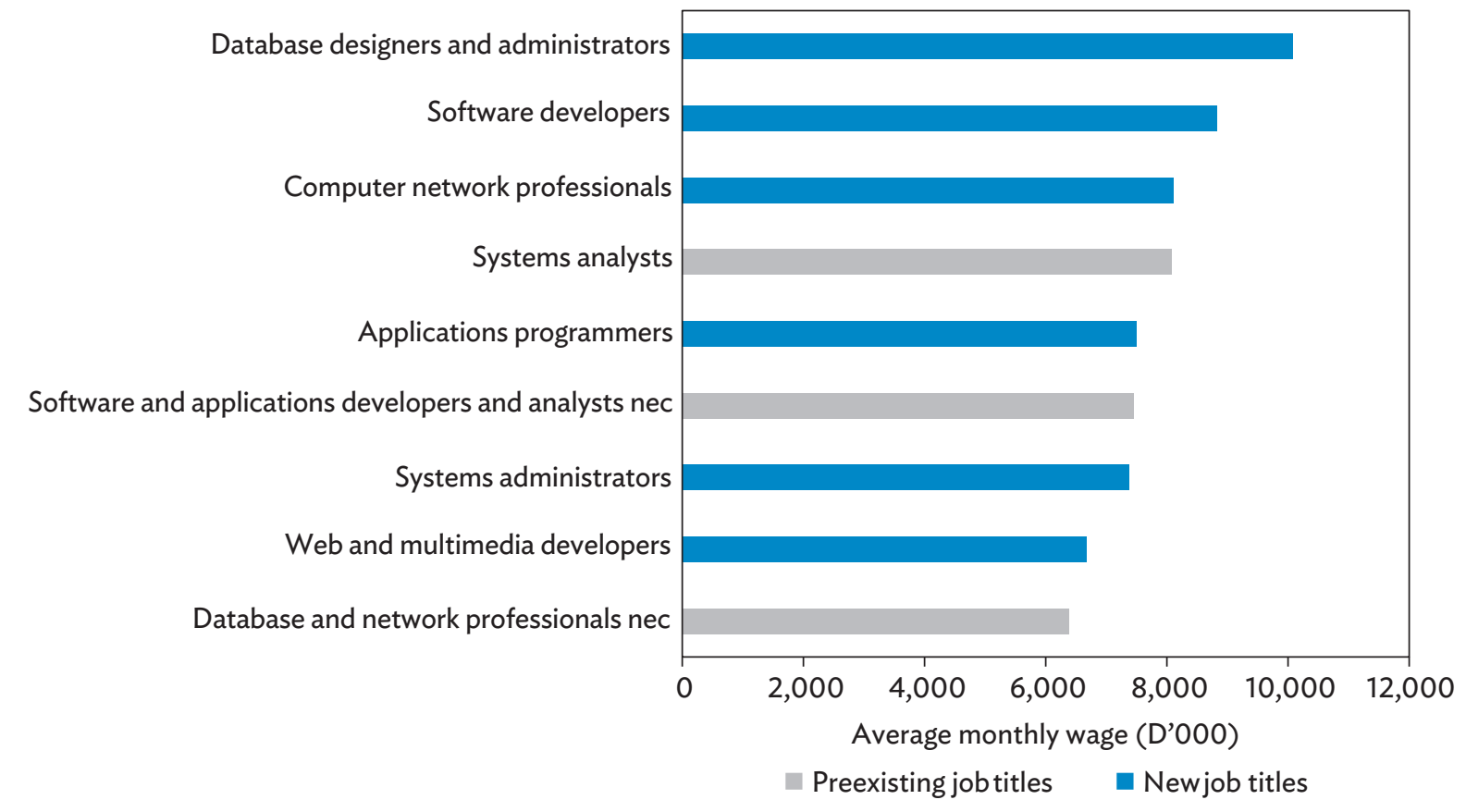

nec $=$ not elsewhere classified.

Note: Average monthly wages of information and communication technology professional wageworkers (urban based and with tertiary education) in new and preexisting job titles.

Source: Authors' calculations using Viet Nam 2015 Labor Force Survey. 


\section{Appendix 7}

\section{Figure A7: Average Monthly Wages of Wageworkers in the Service Sector}

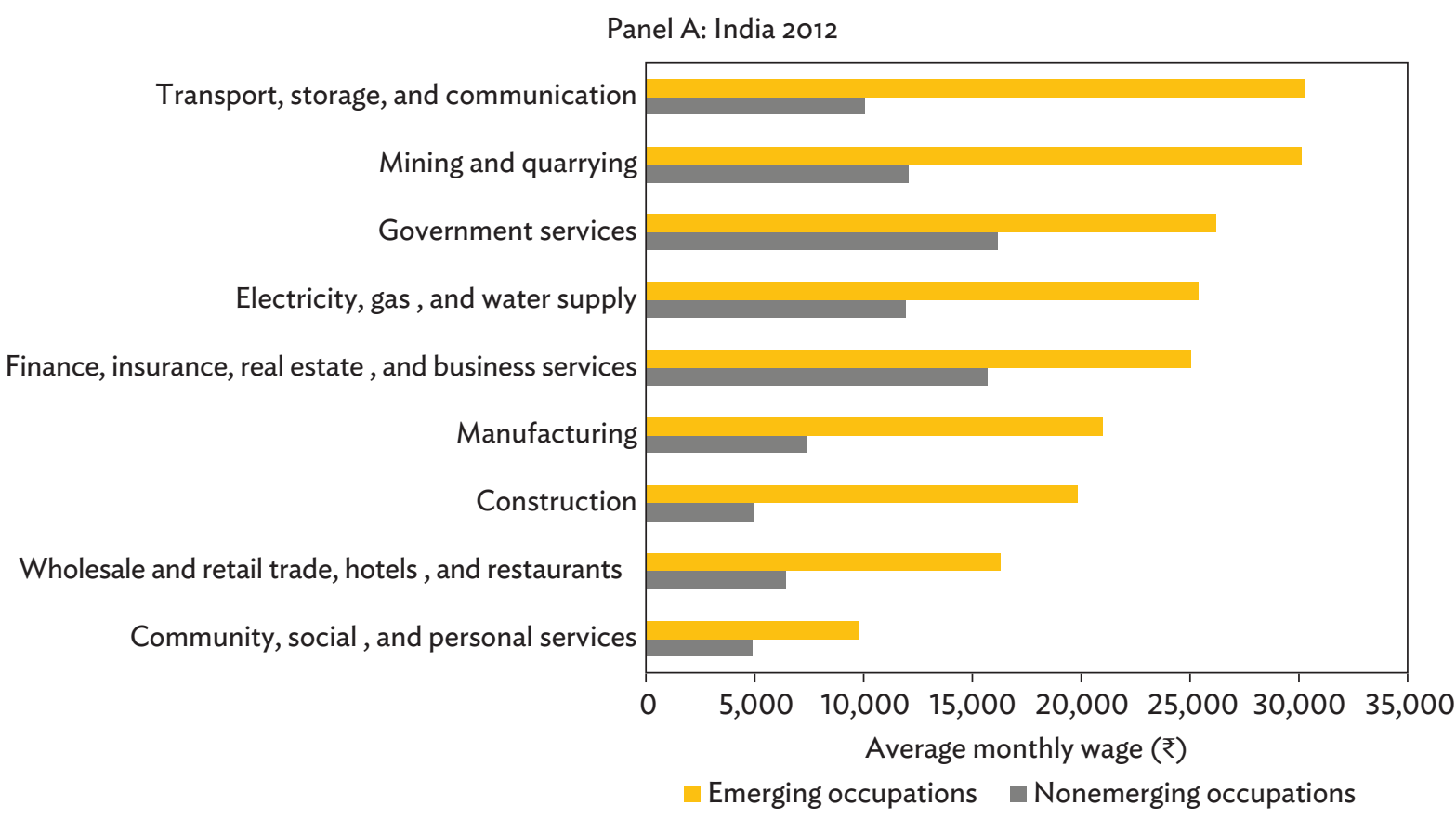

Panel B: Viet Nam 2015

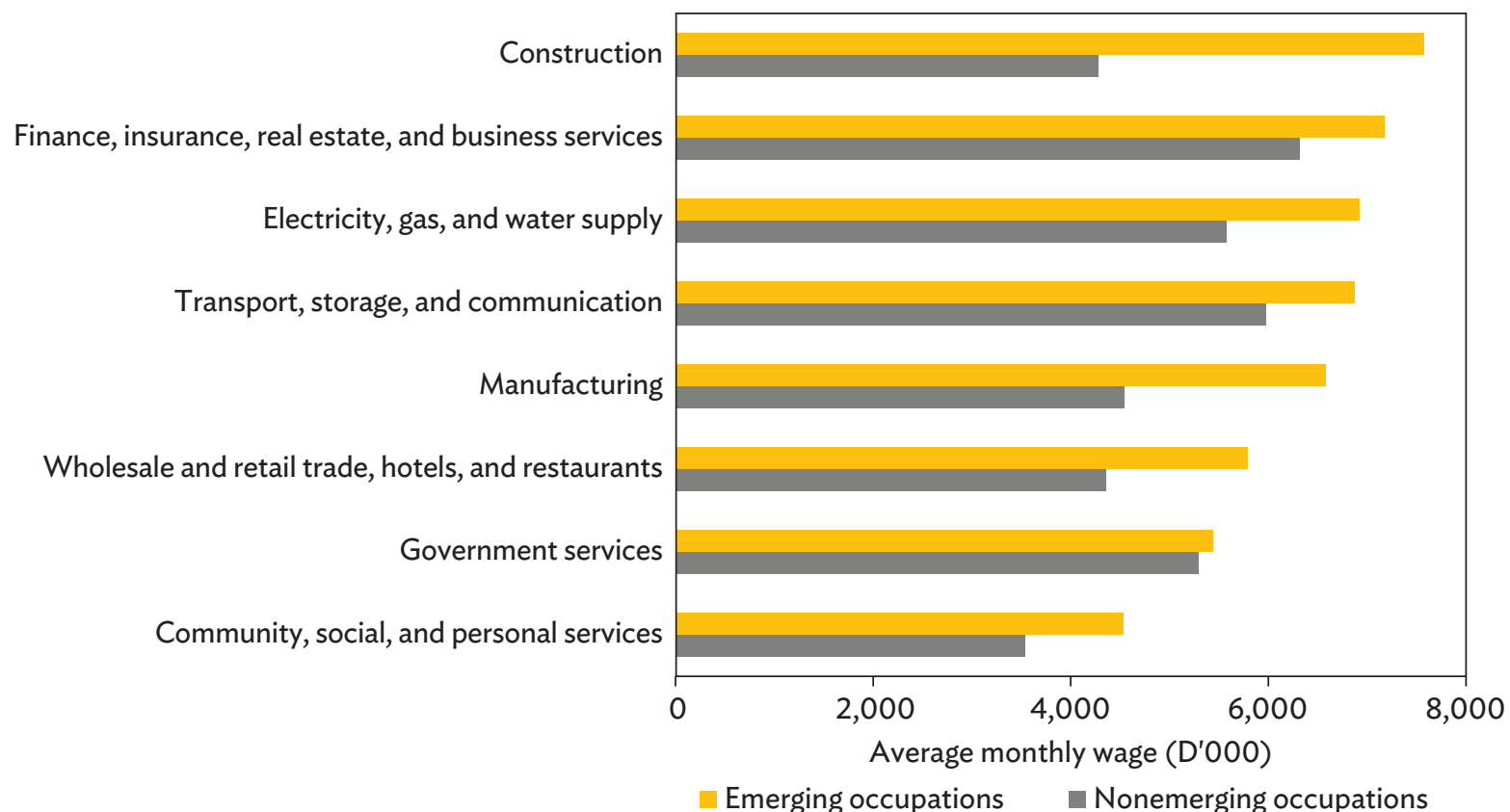

Notes: Average monthly wages (in local currency unit) of wageworkers. We do not report the wages of wageworkers in the agriculture sector because agricultural workers are mostly self-employed. We also do not report the wages of emerging occupation wageworkers in the mining industry in the case of Viet Nam due to insufficient number of observations.

Source: Authors' calculations using Viet Nam 2015 and India 2012 Labor Force Surveys. 


\section{Appendix 8: Multiple Job Holdings}

One potential concern to this analysis is that the paper only looks at workers' primary occupation groups, even though multiple job holdings are rather common in developing Asia. One way of addressing this is by utilizing a "broader" definition of the dependent variable $y$ in the logit model as a robustness check, i.e., an individual is considered an emerging occupation worker if his or her primary and/or subsidiary occupation group is an emerging occupation group. However, it must be noted that one of the limitations of this approach is that we do not know the extent of involvement of a worker in his or her respective subsidiary occupation, whereas a more or less full-time involvement can be expected with main and/or primary occupations. Despite this limitation, we conduct this brief logit exercise using India 2012 as an example.

The analysis of the 2012 India dataset shows that approximately 309.4 million workers (83\%) are engaged in primary occupations only, whereas 63.7 million workers (17\%) are engaged in both primary and subsidiary occupations, and approximately 32,000 (0.01\%) are engaged in subsidiary occupations only (Figure A8.1). A closer look further shows that approximately 860,000 workers $(1.35 \%)$ of these workers are in subsidiary occupations that can be classified as emerging occupation groups (Figure A8.2). Nonetheless, utilizing a broader definition of emerging occupations, i.e., covering subsidiary occupations on top of primary occupations, increases the total employment in emerging occupation groups in India 2012 from approximately 13.5 million (3.63\%) to 14.3 million (3.83\%). Indeed, while this may constitute a small change in terms of percentage, it may be argued that an additional 860,000 emerging occupation workers is not a negligible amount.
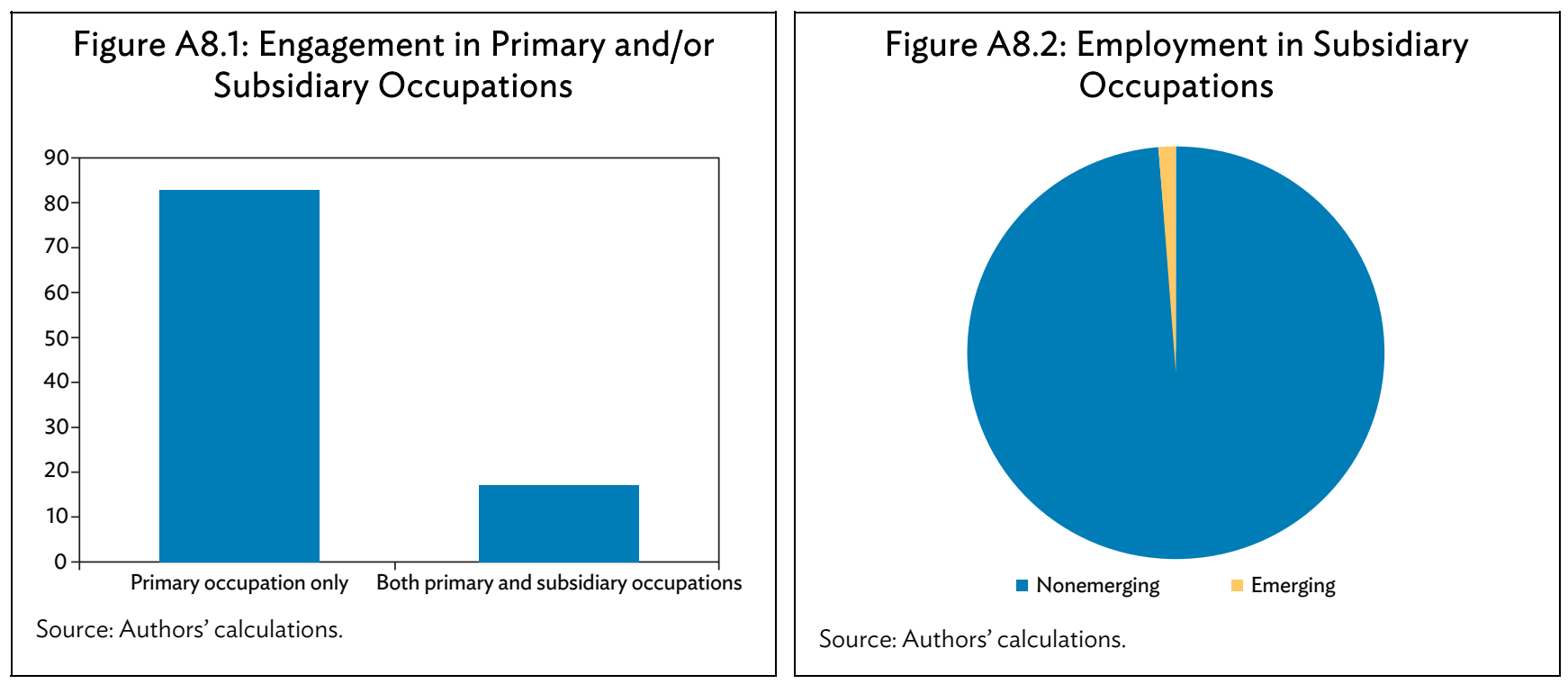

Controlling for region and work experience, logit results with the modified dependent variable largely show similar results found in the main analysis of this paper. Interestingly, the one-and onlystark difference is evident in the sector variable in that the odds ratios have decreased from 21.36 for manufacturing to 27.36 for services as found when using the original dependent variable. Instead, when using the modified dependent variable, the odds of success of workers in the manufacturing and service sectors are 7.10 and 9.13 times, respectively, greater than the odds of success of a worker in the agriculture sector. 
Table A8: Multiple Job Holdings, India 2012

Estimates from logit model of occupation selection (employed $>=15$ and $\langle=65$ years)

Dependent variable $=1$ if employed in emerging occupation

\begin{tabular}{|c|c|c|c|c|c|c|c|c|c|c|c|c|}
\hline & \multicolumn{4}{|c|}{$(0)$} & \multicolumn{4}{|c|}{ (1) } & \multicolumn{4}{|c|}{ (2) } \\
\hline & \multicolumn{2}{|c|}{ 2012_orig } & \multicolumn{2}{|c|}{ 2012_mod } & \multicolumn{2}{|c|}{ 2012_orig } & \multicolumn{2}{|c|}{ 2012_mod } & \multicolumn{2}{|c|}{ 2012_orig } & \multicolumn{2}{|c|}{ 2012_mod } \\
\hline & Coef & OR & Coef & OR & Coef & OR & Coef & OR & Coef & OR & Coef & OR \\
\hline Manufacturing & $\begin{array}{l}3.071^{* * *} \\
(0.244)\end{array}$ & $\begin{array}{l}21.56^{* * *} \\
(5.263)\end{array}$ & $\begin{array}{l}1.970^{* * *} \\
(0.197)\end{array}$ & $\begin{array}{c}7.174^{* * *} \\
(1.413)\end{array}$ & $\begin{array}{l}3.071^{* * *} \\
(0.244)\end{array}$ & $\begin{array}{l}21.56^{* * *} \\
(5.264)\end{array}$ & $\begin{array}{l}1.971^{* * *} \\
(0.197)\end{array}$ & $\begin{array}{c}7.175^{* * *} \\
(1.413)\end{array}$ & $\begin{array}{l}3.062^{* * *} \\
(0.248)\end{array}$ & $\begin{array}{l}21.36^{* * *} \\
(5.297)\end{array}$ & $\begin{array}{l}1.960^{* * *} \\
(0.201)\end{array}$ & $\begin{array}{l}7.102^{* * *} \\
(1.430)\end{array}$ \\
\hline Services & $\begin{array}{l}3.307^{* * *} \\
(0.234)\end{array}$ & $\begin{array}{c}27.30^{* * *} \\
(6.393)\end{array}$ & $\begin{array}{c}2.214^{* * *} \\
(0.183)\end{array}$ & $\begin{array}{l}9.152^{* * *} \\
(1.672)\end{array}$ & $\begin{array}{l}3.307^{* * *} \\
(0.234)\end{array}$ & $\begin{array}{c}27.30^{* * *} \\
(6.393)\end{array}$ & $\begin{array}{l}2.214^{* * *} \\
(0.183)\end{array}$ & $\begin{array}{l}9.152^{* * *} \\
(1.672)\end{array}$ & $\begin{array}{l}3.309^{* * *} \\
(0.235)\end{array}$ & $\begin{array}{c}27.36^{* * *} \\
(6.431)\end{array}$ & $\begin{array}{l}2.212^{* * *} \\
(0.185)\end{array}$ & $\begin{array}{l}9.132^{* * *} \\
(1.688)\end{array}$ \\
\hline Age group 25-34 & $\begin{array}{l}0.417^{* * *} \\
(0.123)\end{array}$ & $\begin{array}{l}1.518^{* * *} \\
(0.187)\end{array}$ & $\begin{array}{c}0.470^{* * *} \\
(0.123)\end{array}$ & $\begin{array}{l}1.601^{* * *} \\
(0.198)\end{array}$ & $\begin{array}{c}0.424^{* * *} \\
(0.125)\end{array}$ & $\begin{array}{c}1.528^{* * *} \\
(0.191)\end{array}$ & $\begin{array}{c}0.454^{* * *} \\
(0.127)\end{array}$ & $\begin{array}{l}1.574^{* * *} \\
(0.200)\end{array}$ & $\begin{array}{l}0.430^{* * *} \\
(0.125)\end{array}$ & $\begin{array}{l}1.537^{* * *} \\
(0.192)\end{array}$ & $\begin{array}{c}0.454^{* * *} \\
(0.127)\end{array}$ & $\begin{array}{l}1.575^{* * *} \\
(0.201)\end{array}$ \\
\hline Age group 35-44 & $\begin{array}{l}0.421^{* * *} \\
(0.126)\end{array}$ & $\begin{array}{l}1.523^{* * *} \\
(0.192)\end{array}$ & $\begin{array}{c}0.499^{* * *} \\
(0.122)\end{array}$ & $\begin{array}{l}1.647^{* * *} \\
(0.200)\end{array}$ & $\begin{array}{l}0.437^{* *} \\
(0.173)\end{array}$ & $\begin{array}{l}1.548^{* *} \\
(0.267)\end{array}$ & $\begin{array}{c}0.458^{* * *} \\
(0.171)\end{array}$ & $\begin{array}{l}1.581^{* * *} \\
(0.270)\end{array}$ & $\begin{array}{l}0.455^{* * *} \\
(0.171)\end{array}$ & $\begin{array}{l}1.577^{* * *} \\
(0.269)\end{array}$ & $\begin{array}{l}0.471^{* * *} \\
(0.169)\end{array}$ & $\begin{array}{c}1.602^{* * *} \\
(0.271)\end{array}$ \\
\hline Age group 45-54 & $\begin{array}{c}0.503^{* * *} \\
(0.143)\end{array}$ & $\begin{array}{l}1.653^{* * *} \\
(0.237)\end{array}$ & $\begin{array}{c}0.543^{* * *} \\
(0.139)\end{array}$ & $\begin{array}{l}1.721^{1 * *} \\
(0.239)\end{array}$ & $\begin{array}{l}0.530^{* *} \\
(0.229)\end{array}$ & $\begin{array}{l}1.699^{* *} \\
(0.389)\end{array}$ & $\begin{array}{l}0.476^{* *} \\
(0.237)\end{array}$ & $\begin{array}{l}1.610^{* *} \\
(0.381)\end{array}$ & $\begin{array}{l}0.552^{* *} \\
(0.228)\end{array}$ & $\begin{array}{l}1.737^{* *} \\
(0.396)\end{array}$ & $\begin{array}{l}0.496^{* *} \\
(0.235)\end{array}$ & $\begin{array}{l}1.642^{* *} \\
(0.387)\end{array}$ \\
\hline Age group 55-65 & $\begin{array}{c}0.623^{* * *} \\
(0.155)\end{array}$ & $\begin{array}{l}1.864^{* * *} \\
(0.289)\end{array}$ & $\begin{array}{l}0.638^{* * *} \\
(0.150)\end{array}$ & $\begin{array}{l}1.892^{* * *} \\
(0.285)\end{array}$ & $\begin{array}{l}0.660^{* *} \\
(0.300)\end{array}$ & $\begin{array}{l}1.935^{* *} \\
(0.581)\end{array}$ & $\begin{array}{l}0.545^{*} \\
(0.312)\end{array}$ & $\begin{array}{l}1.724^{*} \\
(0.538)\end{array}$ & $\begin{array}{l}0.700^{* *} \\
(0.299)\end{array}$ & $\begin{array}{l}2.014^{* *} \\
(0.602)\end{array}$ & $\begin{array}{l}0.583^{*} \\
(0.310)\end{array}$ & $\begin{array}{l}1.792^{*} \\
(0.556)\end{array}$ \\
\hline Male & $\begin{array}{l}-0.0277 \\
(0.0616)\end{array}$ & $\begin{array}{c}0.973 \\
(0.0599)\end{array}$ & $\begin{array}{c}0.0312 \\
(0.0586)\end{array}$ & $\begin{array}{c}1.032 \\
(0.0605)\end{array}$ & $\begin{array}{l}-0.0275 \\
(0.0616)\end{array}$ & $\begin{array}{c}0.973 \\
(0.0599)\end{array}$ & $\begin{array}{c}0.0307 \\
(0.0585)\end{array}$ & $\begin{array}{c}1.031 \\
(0.0603)\end{array}$ & $\begin{array}{l}0.00976 \\
(0.0631)\end{array}$ & $\begin{array}{c}1.010 \\
(0.0638)\end{array}$ & $\begin{array}{c}0.0640 \\
(0.0601)\end{array}$ & $\begin{array}{c}1.066 \\
(0.0641)\end{array}$ \\
\hline Primary & $\begin{array}{l}0.269^{* *} \\
(0.119)\end{array}$ & $\begin{array}{l}1.309^{* *} \\
(0.156)\end{array}$ & $\begin{array}{l}0.377^{* * *} \\
(0.125)\end{array}$ & $\begin{array}{l}1.458^{* * *} \\
(0.183)\end{array}$ & $\begin{array}{l}0.264^{* *} \\
(0.129)\end{array}$ & $\begin{array}{l}1.302^{* *} \\
(0.168)\end{array}$ & $\begin{array}{l}0.390^{* * *} \\
(0.129)\end{array}$ & $\begin{array}{l}1.477^{* * *} \\
(0.190)\end{array}$ & $\begin{array}{l}0.258^{* *} \\
(0.129)\end{array}$ & $\begin{array}{l}1.294^{* *} \\
(0.167)\end{array}$ & $\begin{array}{l}0.378^{* * *} \\
(0.128)\end{array}$ & $\begin{array}{l}1.459^{* * *} \\
(0.186)\end{array}$ \\
\hline Middle & $\begin{array}{c}0.800^{* * *} \\
(0.136)\end{array}$ & $\begin{array}{l}2.226^{* * *} \\
(0.302)\end{array}$ & $\begin{array}{l}0.792^{* * *} \\
(0.122)\end{array}$ & $\begin{array}{l}2.209^{* * *} \\
(0.269)\end{array}$ & $\begin{array}{l}0.792^{* * *} \\
(0.167)\end{array}$ & $\begin{array}{l}2.207^{* * *} \\
(0.368)\end{array}$ & $\begin{array}{l}0.814^{* * *} \\
(0.149)\end{array}$ & $\begin{array}{l}2.256^{* * *} \\
(0.336)\end{array}$ & $\begin{array}{l}0.766^{* * *} \\
(0.166)\end{array}$ & $\begin{array}{l}2.150^{* * *} \\
(0.357)\end{array}$ & $\begin{array}{c}0.783^{* * *} \\
(0.147)\end{array}$ & $\begin{array}{l}2.188^{* * *} \\
(0.322)\end{array}$ \\
\hline Secondary & $\begin{array}{l}1.585^{* * *} \\
(0.134)\end{array}$ & $\begin{array}{l}4.879^{* * *} \\
(0.652)\end{array}$ & $\begin{array}{l}1.554^{* * *} \\
(0.126)\end{array}$ & $\begin{array}{l}4.730^{* * *} \\
(0.597)\end{array}$ & $\begin{array}{l}1.574^{* * *} \\
(0.181)\end{array}$ & $\begin{array}{l}4.824^{* * *} \\
(0.874)\end{array}$ & $\begin{array}{l}1.582^{* * *} \\
(0.165)\end{array}$ & $\begin{array}{l}4.863^{* * *} \\
(0.805)\end{array}$ & $\begin{array}{l}1.539^{* * *} \\
(0.182)\end{array}$ & $\begin{array}{l}4.660^{* * *} \\
(0.847)\end{array}$ & $\begin{array}{l}1.546^{* * *} \\
(0.165)\end{array}$ & $\begin{array}{l}4.694^{* * *} \\
(0.774)\end{array}$ \\
\hline Tertiary & $\begin{array}{c}2.977^{* * *} \\
(0.129)\end{array}$ & $\begin{array}{l}19.64^{* * *} \\
(2.538)\end{array}$ & $\begin{array}{l}2.911^{* * *} \\
(0.127)\end{array}$ & $\begin{array}{l}18.37^{* * *} \\
(2.336)\end{array}$ & $\begin{array}{l}2.961^{* * *} \\
(0.191)\end{array}$ & $\begin{array}{l}19.31^{* * *} \\
(3.685)\end{array}$ & $\begin{array}{c}2.952^{* * *} \\
(0.179)\end{array}$ & $\begin{array}{l}19.14^{* * *} \\
(3.419)\end{array}$ & $\begin{array}{l}2.929^{* * *} \\
(0.191)\end{array}$ & $\begin{array}{l}18.71^{* * *} \\
(3.575)\end{array}$ & $\begin{array}{l}2.916^{* * *} \\
(0.178)\end{array}$ & $\begin{array}{l}18.47^{* * *} \\
(3.287)\end{array}$ \\
\hline
\end{tabular}




\begin{tabular}{|c|c|c|c|c|c|c|c|c|c|c|c|c|}
\hline & \multicolumn{4}{|c|}{$(0)$} & \multicolumn{4}{|c|}{ (1) } & \multicolumn{4}{|c|}{ (2) } \\
\hline & \multicolumn{2}{|c|}{ 2012_orig } & \multicolumn{2}{|c|}{ 2012_mod } & \multicolumn{2}{|c|}{ 2012_orig } & \multicolumn{2}{|c|}{ 2012_mod } & \multicolumn{2}{|c|}{ 2012_orig } & \multicolumn{2}{|c|}{ 2012_mod } \\
\hline & Coef & OR & Coef & OR & Coef & OR & Coef & OR & Coef & OR & Coef & OR \\
\hline \multirow[t]{2}{*}{ Urban } & $0.429^{* * *}$ & $1.535^{* * *}$ & $0.408^{* * *}$ & $1.503^{* * *}$ & $0.429^{* * *}$ & $1.536^{* * *}$ & $0.407^{* * *}$ & $1.503^{* * *}$ & $0.392^{* * *}$ & $1.480^{* * *}$ & $0.381^{* * *}$ & $1.464^{* * *}$ \\
\hline & $(0.0833)$ & $(0.128)$ & $(0.0815)$ & $(0.123)$ & $(0.0835)$ & $(0.128)$ & $(0.0817)$ & $(0.123)$ & $(0.0835)$ & $(0.124)$ & $(0.0802)$ & $(0.117)$ \\
\hline \multirow[t]{2}{*}{ Married } & -0.0814 & 0.922 & -0.0753 & 0.927 & -0.0793 & 0.924 & -0.0804 & 0.923 & -0.0736 & 0.929 & -0.0659 & 0.936 \\
\hline & $(0.0912)$ & $(0.0841)$ & $(0.0895)$ & $(0.0830)$ & $(0.0977)$ & $(0.0903)$ & $(0.0949)$ & $(0.0876)$ & $(0.0947)$ & $(0.0879)$ & $(0.0925)$ & $(0.0866)$ \\
\hline \multirow[t]{2}{*}{ Separated/widowed } & -0.0749 & 0.928 & -0.0542 & 0.947 & -0.0720 & 0.931 & -0.0613 & 0.941 & -0.0700 & 0.932 & -0.0494 & 0.952 \\
\hline & $(0.171)$ & $(0.159)$ & $(0.171)$ & $(0.162)$ & $(0.182)$ & $(0.169)$ & $(0.180)$ & $(0.169)$ & $(0.181)$ & $(0.169)$ & $(0.180)$ & $(0.171)$ \\
\hline $\begin{array}{l}\text { Pot. work exp. } \\
\text { controls }\end{array}$ & \multicolumn{2}{|c|}{ No } & \multicolumn{2}{|c|}{ No } & \multicolumn{2}{|c|}{ Yes } & \multicolumn{2}{|c|}{ Yes } & \multicolumn{2}{|c|}{ Yes } & \multicolumn{2}{|c|}{ Yes } \\
\hline Region controls & \multicolumn{2}{|c|}{ No } & \multicolumn{2}{|c|}{ No } & \multicolumn{2}{|c|}{ No } & \multicolumn{2}{|c|}{ No } & \multicolumn{2}{|c|}{ Yes } & \multicolumn{2}{|c|}{ Yes } \\
\hline Observations & \multicolumn{2}{|c|}{153,387} & \multicolumn{2}{|c|}{153,387} & \multicolumn{2}{|c|}{153,387} & \multicolumn{2}{|c|}{153,387} & \multicolumn{2}{|c|}{153,387} & \multicolumn{2}{|c|}{153,387} \\
\hline Wald chi2 $\left(^{*}\right)$ & \multicolumn{2}{|c|}{ (14) 2693.78} & \multicolumn{2}{|c|}{ (14) 2531.20} & \multicolumn{2}{|c|}{ (15) 2755.53} & \multicolumn{2}{|c|}{ (15) 2744.73} & \multicolumn{2}{|c|}{ (19) 3027.85} & (19) 28 & 0.96 \\
\hline Prob > chi2 & & 0.000 & & .0000 & & 0.000 & & 0.000 & & .000 & & .000 \\
\hline Pseudo R-squared & & 0.2865 & & 0.2595 & & .2865 & & .2595 & & 2886 & & 2609 \\
\hline
\end{tabular}

Coef $=$ coefficient, $\mathrm{OR}=$ odds ratio

Notes: 2012_orig refers to logit estimates using the original dependent variable (considering primary occupations only), whereas 2012_mod refers to the logit estimates using the modified dependent variable, i.e., considering both the primary and subsidiary occupations of workers. Robust standard errors in parentheses. Adjusted for clustering. ${ }^{* *}$, **, and ${ }^{*}$ indicate significance at $1 \%, 5 \%$, and $10 \%$, respectively. Wald chi2 $\left(^{*}\right)$ in parentheses per model ran. Pot. work exp. refers to potential years of work experience, which is a generated continuous control variable following the equation: age - years of schooling -6 , where 6 is assumed to be the age of entry to school. The reference categories for each variable are: 15-24 for age group, female for gender, none to preprimary for education, agriculture for sector, rural for location, single for marital status.

Source: Authors' calculations. 


\section{Appendix 9}

Table A9: Stacked Datasets in One Logit Model, India 2000 and 2012

Estimates from logit model of occupation selection (employed $>=15$ and $<=65$ years)

Dependent variable $=1$ if employed in emerging occupation

\begin{tabular}{|c|c|c|c|c|}
\hline & \multicolumn{2}{|c|}{$(1)$} & \multicolumn{2}{|c|}{$(2)$} \\
\hline & Coef & OR & Coef & OR \\
\hline \multirow[t]{2}{*}{ 2000.year } & -0.0304 & 0.970 & 0.114 & 1.120 \\
\hline & $(0.434)$ & $(0.421)$ & $(0.464)$ & $(0.520)$ \\
\hline \multirow[t]{2}{*}{ 2000.year\#manufacturing } & $2.680^{* * *}$ & $14.59^{* * *}$ & $2.680^{* * *}$ & $14.58^{* * *}$ \\
\hline & $(0.133)$ & $(1.944)$ & $(0.135)$ & $(1.971)$ \\
\hline \multirow[t]{2}{*}{ 2000.year\#services } & $3.120^{* * *}$ & $22.64^{* * *}$ & $3.118^{* * *}$ & $22.60^{* * *}$ \\
\hline & $(0.180)$ & $(4.066)$ & $(0.180)$ & $(4.058)$ \\
\hline \multirow[t]{2}{*}{ 2012.year\#manufacturing } & $3.071^{* * *}$ & $21.56^{* * *}$ & $3.062^{* * *}$ & $21.36^{* * *}$ \\
\hline & $(0.244)$ & $(5.259)$ & $(0.248)$ & (5.291) \\
\hline \multirow[t]{2}{*}{ 2012.year\#services } & $3.307^{* * *}$ & $27.30^{* * *}$ & $3.309^{* * *}$ & $27.36^{* * *}$ \\
\hline & $(0.234)$ & $(6.387)$ & $(0.235)$ & $(6.424)$ \\
\hline \multirow[t]{2}{*}{ 2000.year\#age_grp25-34 } & $0.202^{* *}$ & $1.223^{* *}$ & $0.200^{* *}$ & $1.221^{* *}$ \\
\hline & $(0.0897)$ & $(0.110)$ & $(0.0896)$ & $(0.109)$ \\
\hline \multirow[t]{2}{*}{ 2000.year\#age_grp35-44 } & 0.127 & 1.135 & 0.127 & 1.135 \\
\hline & $(0.123)$ & $(0.140)$ & $(0.123)$ & $(0.139)$ \\
\hline \multirow[t]{2}{*}{ 2000.year\#age_grp45-54 } & 0.133 & 1.142 & 0.129 & 1.137 \\
\hline & $(0.172)$ & $(0.196)$ & $(0.173)$ & (0.197) \\
\hline \multirow[t]{2}{*}{ 2000.year\#age_grp55-65 } & -0.0146 & 0.986 & -0.0160 & 0.984 \\
\hline & $(0.218)$ & $(0.214)$ & $(0.222)$ & $(0.218)$ \\
\hline \multirow[t]{2}{*}{ 2012.year\#age_grp25-34 } & $0.424^{* * *}$ & $1.528^{* * *}$ & $0.430^{* * *}$ & $1.537^{* * *}$ \\
\hline & $(0.125)$ & $(0.191)$ & $(0.125)$ & $(0.192)$ \\
\hline \multirow[t]{2}{*}{ 2012.year\#age_grp35-44 } & $0.437^{* *}$ & $1.548^{* *}$ & $0.455^{* * *}$ & $1.577^{* * *}$ \\
\hline & $(0.172)$ & $(0.267)$ & $(0.170)$ & $(0.269)$ \\
\hline \multirow[t]{2}{*}{ 2012.year\#age_grp45-54 } & $0.530^{* *}$ & $1.699^{* *}$ & $0.552^{* *}$ & $1.737^{* *}$ \\
\hline & $(0.229)$ & $(0.389)$ & $(0.228)$ & $(0.396)$ \\
\hline \multirow[t]{2}{*}{ 2012.year\#age_grp55-65 } & $0.660^{* *}$ & $1.935^{* *}$ & $0.700^{* *}$ & $2.014^{* *}$ \\
\hline & $(0.300)$ & $(0.581)$ & $(0.299)$ & $(0.602)$ \\
\hline \multirow[t]{2}{*}{ 2000.year\#male } & $0.501^{* * *}$ & $1.651^{1 * *}$ & $0.519^{* * *}$ & $1.681^{* * *}$ \\
\hline & $(0.103)$ & $(0.169)$ & $(0.0978)$ & $(0.164)$ \\
\hline \multirow[t]{2}{*}{ 2012.year\#male } & -0.0275 & 0.973 & 0.00974 & 1.010 \\
\hline & $(0.0615)$ & $(0.0598)$ & $(0.0631)$ & $(0.0637)$ \\
\hline \multirow[t]{2}{*}{ 2000.year\#primary } & $0.298^{* *}$ & $1.347^{* *}$ & $0.308^{* *}$ & $1.361^{* *}$ \\
\hline & $(0.142)$ & $(0.192)$ & $(0.149)$ & $(0.203)$ \\
\hline \multirow[t]{2}{*}{ 2000.year\#middle } & $1.090^{* * *}$ & $2.975^{* * *}$ & $1.108^{* * *}$ & $3.029^{* * *}$ \\
\hline & $(0.121)$ & $(0.359)$ & $(0.128)$ & $(0.388)$ \\
\hline
\end{tabular}


Table A9 continued

\begin{tabular}{|c|c|c|c|c|}
\hline & \multicolumn{2}{|c|}{ (1) } & \multicolumn{2}{|c|}{$(2)$} \\
\hline & Coef & OR & Coef & OR \\
\hline \multirow[t]{2}{*}{ 2000.year\#secondary } & $1.861^{* * *}$ & $6.431^{* * *}$ & $1.872^{* * *}$ & $6.500^{* * *}$ \\
\hline & $(0.141)$ & $(0.905)$ & $(0.148)$ & $(0.960)$ \\
\hline \multirow[t]{2}{*}{ 2000.year\#tertiary } & $2.548^{* * *}$ & $12.79^{* * *}$ & $2.563^{* * *}$ & $12.98^{* * *}$ \\
\hline & $(0.156)$ & $(1.989)$ & $(0.159)$ & (2.066) \\
\hline \multirow[t]{2}{*}{ 2012.year\#primary } & $0.264^{* *}$ & $1.302^{* *}$ & $0.258^{* *}$ & $1.294^{* *}$ \\
\hline & $(0.129)$ & $(0.168)$ & $(0.129)$ & $(0.167)$ \\
\hline \multirow[t]{2}{*}{ 2012.year\#middle } & $0.792^{* * *}$ & $2.207^{* * *}$ & $0.766^{* * *}$ & $2.150^{* * *}$ \\
\hline & $(0.167)$ & $(0.368)$ & $(0.166)$ & $(0.357)$ \\
\hline \multirow[t]{2}{*}{ 2012.year\#secondary } & $1.574^{* * *}$ & $4.824^{* * *}$ & $1.539^{* * *}$ & $4.660^{* * *}$ \\
\hline & $(0.181)$ & $(0.873)$ & $(0.182)$ & $(0.846)$ \\
\hline \multirow[t]{2}{*}{ 2012.year\#tertiary } & $2.961^{* * *}$ & $19.31^{* * *}$ & $2.929^{* * *}$ & $18.71^{* * *}$ \\
\hline & $(0.191)$ & $(3.681)$ & $(0.191)$ & (3.571) \\
\hline \multirow[t]{2}{*}{ 2000.year\#workexp } & $0.0151^{* *}$ & $1.015^{* *}$ & $0.0155^{* *}$ & $1.016^{* *}$ \\
\hline & $(0.00609)$ & $(0.00618)$ & $(0.00633)$ & $(0.00643)$ \\
\hline \multirow[t]{2}{*}{ 2012.year\#workexp } & -0.00108 & 0.999 & -0.00136 & 0.999 \\
\hline & $(0.00887)$ & $(0.00886)$ & $(0.00868)$ & $(0.00867)$ \\
\hline \multirow[t]{2}{*}{ 2000.year\#urban } & $0.221^{* * *}$ & $1.247^{* * *}$ & $0.219^{* * *}$ & $1.245^{* * *}$ \\
\hline & $(0.0672)$ & $(0.0838)$ & $(0.0657)$ & $(0.0818)$ \\
\hline \multirow[t]{2}{*}{ 2012.year\#urban } & $0.429^{* * *}$ & $1.536^{* * *}$ & $0.392^{* * *}$ & $1.480^{* * *}$ \\
\hline & $(0.0835)$ & $(0.128)$ & $(0.0834)$ & $(0.123)$ \\
\hline \multirow[t]{2}{*}{ 2000.year\#married } & $-0.266^{* * *}$ & $0.766^{* * *}$ & $-0.265^{* * *}$ & $0.767^{* * *}$ \\
\hline & $(0.0807)$ & $(0.0618)$ & $(0.0717)$ & $(0.0550)$ \\
\hline \multirow[t]{2}{*}{ 2000.year\#separated/widowed } & $-0.515^{* *}$ & $0.598^{* *}$ & $-0.515^{* *}$ & $0.597^{* *}$ \\
\hline & $(0.234)$ & $(0.140)$ & $(0.223)$ & $(0.133)$ \\
\hline \multirow[t]{2}{*}{ 2012.year\#married } & -0.0793 & 0.924 & -0.0736 & 0.929 \\
\hline & $(0.0976)$ & $(0.0902)$ & $(0.0946)$ & $(0.0879)$ \\
\hline \multirow[t]{2}{*}{ 2012.year\#separated/widowed } & -0.0719 & 0.931 & -0.0700 & 0.932 \\
\hline & $(0.182)$ & $(0.169)$ & $(0.181)$ & $(0.169)$ \\
\hline years\#region & \multicolumn{2}{|c|}{ No } & \multicolumn{2}{|c|}{ Yes } \\
\hline Observations & \multicolumn{4}{|c|}{429,353} \\
\hline Wald chi2 $\left(^{*}\right)$ & \multicolumn{2}{|c|}{ (31) 25486.14} & \multicolumn{2}{|c|}{ (39) 44804.60} \\
\hline Prob > chi2 & \multicolumn{2}{|c|}{0.000} & \multicolumn{2}{|c|}{0.000} \\
\hline Pseudo R-squared & \multicolumn{2}{|c|}{0.2787} & \multicolumn{2}{|c|}{0.2805} \\
\hline
\end{tabular}

Coef. = coefficient, $\mathrm{OR}=$ odds ratio.

Notes: Robust standard errors in parentheses. Adjusted for clustering. ${ }^{* *},{ }^{* *}$, and ${ }^{*}$ indicate significance at $1 \%, 5 \%$, and $10 \%$, respectively. Wald chi2 $\left(^{*}\right)$ in parentheses per model ran. Reference categories with coefficients and odds ratios of 0 and 1 , respectively, are omitted. The reference categories for each variable are: year\#(15-24) for age group, female for sex, none to preprimary for education, agriculture for sector, rural for location, single for marital status.

Source: Authors' calculations. 


\section{Appendix 10}

Table A10: Stacked Datasets in One Logit Model, Viet Nam 2013 and 2015

Estimates from logit model of occupation selection (employed $>=15$ and $<=65$ years)

Dependent variable $=1$ if employed in emerging occupation

\begin{tabular}{|c|c|c|c|c|}
\hline & \multicolumn{2}{|c|}{ (1) } & \multicolumn{2}{|c|}{$(2)$} \\
\hline & Coef & OR & Coef & OR \\
\hline \multirow[t]{2}{*}{ 2013bn.year } & 0.164 & 0.164 & 0.130 & 0.130 \\
\hline & $(0.304)$ & $(0.304)$ & $(0.322)$ & $(0.322)$ \\
\hline \multirow[t]{2}{*}{ 2013bn.year\#manufacturing } & $2.510^{* * *}$ & $2.510^{* * *}$ & $2.401^{* * *}$ & $2.401^{* * *}$ \\
\hline & $(0.282)$ & $(0.282)$ & $(0.289)$ & $(0.289)$ \\
\hline \multirow[t]{2}{*}{ 2013bn.year\#services } & $3.696^{* * *}$ & $3.696^{* * *}$ & $3.603^{* * *}$ & $3.603^{* * *}$ \\
\hline & $(0.343)$ & $(0.343)$ & $(0.356)$ & $(0.356)$ \\
\hline \multirow[t]{2}{*}{ 2015.year\#manufacturing } & $2.751^{* * *}$ & $2.751^{* * *}$ & $2.692^{* * *}$ & $2.692^{* * *}$ \\
\hline & $(0.234)$ & $(0.234)$ & $(0.250)$ & $(0.250)$ \\
\hline \multirow[t]{2}{*}{ 2015.year\#services } & $3.877^{* * *}$ & $3.877^{* * *}$ & $3.830^{* * *}$ & $3.830^{* * *}$ \\
\hline & $(0.268)$ & $(0.268)$ & $(0.286)$ & $(0.286)$ \\
\hline \multirow[t]{2}{*}{ 2013bn.year\#agegrp25-34 } & $0.289^{* *}$ & $0.289^{* *}$ & $0.263^{* *}$ & $0.263^{* *}$ \\
\hline & $(0.124)$ & $(0.124)$ & $(0.105)$ & $(0.105)$ \\
\hline \multirow[t]{2}{*}{ 2013bn.year\#agegrp35-44 } & 0.357 & 0.357 & $0.341^{*}$ & $0.341^{*}$ \\
\hline & $(0.221)$ & $(0.221)$ & $(0.203)$ & $(0.203)$ \\
\hline \multirow[t]{2}{*}{ 2013bn.year\#agegrp45-54 } & 0.377 & 0.377 & 0.378 & 0.378 \\
\hline & $(0.322)$ & $(0.322)$ & $(0.310)$ & $(0.310)$ \\
\hline \multirow[t]{2}{*}{ 2013bn.year\#agegrp55-65 } & 0.650 & 0.650 & 0.657 & 0.657 \\
\hline & $(0.430)$ & $(0.430)$ & $(0.424)$ & $(0.424)$ \\
\hline \multirow[t]{2}{*}{ 2015.year\#agegrp25-34 } & $0.262^{* * *}$ & $0.262^{* * *}$ & $0.246^{* * *}$ & $0.246^{* * *}$ \\
\hline & $(0.0550)$ & $(0.0550)$ & $(0.0564)$ & $(0.0564)$ \\
\hline \multirow[t]{2}{*}{ 2015.year\#agegrp35-44 } & $0.226^{* *}$ & $0.226^{* *}$ & $0.213^{* *}$ & $0.213^{* *}$ \\
\hline & $(0.112)$ & $(0.112)$ & $(0.105)$ & $(0.105)$ \\
\hline \multirow[t]{2}{*}{ 2015.year\#agegrp45-54 } & 0.0634 & 0.0634 & 0.0624 & 0.0624 \\
\hline & $(0.177)$ & $(0.177)$ & $(0.173)$ & $(0.173)$ \\
\hline \multirow[t]{2}{*}{ 2015.year\#agegrp55-65 } & 0.0212 & 0.0212 & 0.0377 & 0.0377 \\
\hline & $(0.246)$ & $(0.246)$ & $(0.248)$ & $(0.248)$ \\
\hline \multirow[t]{2}{*}{ 2013bn.year\#male } & $0.603^{* * *}$ & $0.603^{* * *}$ & $0.601^{* * *}$ & $0.601^{* * *}$ \\
\hline & $(0.0441)$ & $(0.0441)$ & $(0.0443)$ & $(0.0443)$ \\
\hline \multirow[t]{2}{*}{ 2015.year\#male } & $0.606^{* * *}$ & $0.606^{* * *}$ & $0.606^{* * *}$ & $0.606^{* * *}$ \\
\hline & $(0.0505)$ & $(0.0505)$ & $(0.0500)$ & $(0.0500)$ \\
\hline \multirow[t]{2}{*}{ 2013bn.year\#primary } & -0.0457 & -0.0457 & -0.0324 & -0.0324 \\
\hline & $(0.143)$ & $(0.143)$ & $(0.152)$ & $(0.152)$ \\
\hline \multirow[t]{2}{*}{ 2013bn.year\#secondary } & -0.0792 & -0.0792 & -0.0387 & -0.0387 \\
\hline & $(0.153)$ & $(0.153)$ & $(0.160)$ & $(0.160)$ \\
\hline
\end{tabular}


Table A10 continued

\begin{tabular}{|c|c|c|c|c|}
\hline & \multicolumn{2}{|c|}{ (1) } & \multicolumn{2}{|c|}{$(2)$} \\
\hline & Coef & OR & Coef & OR \\
\hline \multirow[t]{2}{*}{ 2013bn.year\#tertiary } & $1.165^{* * *}$ & $1.165^{* * *}$ & $1.219^{* * *}$ & $1.219^{* * *}$ \\
\hline & $(0.214)$ & $(0.214)$ & $(0.207)$ & $(0.207)$ \\
\hline \multirow[t]{2}{*}{ 2015.year\#primary } & $-0.289^{* *}$ & $-0.289^{* *}$ & $-0.281^{*}$ & $-0.281^{*}$ \\
\hline & $(0.143)$ & $(0.143)$ & $(0.144)$ & $(0.144)$ \\
\hline \multirow[t]{2}{*}{ 2015.year\#secondary } & -0.0782 & -0.0782 & -0.0300 & -0.0300 \\
\hline & $(0.179)$ & $(0.179)$ & $(0.166)$ & $(0.166)$ \\
\hline \multirow[t]{2}{*}{ 2015.year\#tertiary } & $0.918^{* * *}$ & $0.918^{* * *}$ & $0.981^{* * *}$ & $0.981^{* * *}$ \\
\hline & $(0.226)$ & $(0.226)$ & $(0.206)$ & $(0.206)$ \\
\hline \multirow[t]{2}{*}{ 2013bn.year\#workexp } & $-0.0376^{* * *}$ & $-0.0376^{* * *}$ & $-0.0389^{* * *}$ & $-0.0389^{* * *}$ \\
\hline & $(0.0111)$ & $(0.0111)$ & (0.0117) & (0.0117) \\
\hline \multirow[t]{2}{*}{ 2015.year\#workexp } & $-0.0285^{* * *}$ & $-0.0285^{* * *}$ & $-0.0294^{* * *}$ & $-0.0294^{* * *}$ \\
\hline & $(0.00605)$ & $(0.00605)$ & $(0.00622)$ & $(0.00622)$ \\
\hline \multirow[t]{2}{*}{ 2013bn.year\#urban } & $0.452^{* * *}$ & $0.452^{* * *}$ & $0.377^{* * *}$ & $0.377^{* * *}$ \\
\hline & $(0.156)$ & $(0.156)$ & $(0.126)$ & $(0.126)$ \\
\hline \multirow[t]{2}{*}{ 2015.year\#urban } & $0.479^{* * *}$ & $0.479^{* * *}$ & $0.423^{* * *}$ & $0.423^{* * *}$ \\
\hline & $(0.122)$ & $(0.122)$ & $(0.101)$ & $(0.101)$ \\
\hline \multirow[t]{2}{*}{ 2013bn.year\#married } & $-0.248^{* * *}$ & $-0.248^{* * *}$ & $-0.188^{* * *}$ & $-0.188^{* * *}$ \\
\hline & $(0.0578)$ & $(0.0578)$ & $(0.0523)$ & $(0.0523)$ \\
\hline \multirow[t]{2}{*}{ 2013bn.year\#separated/widowed } & $-0.334^{* *}$ & $-0.334^{* *}$ & $-0.289^{* *}$ & $-0.289^{* *}$ \\
\hline & $(0.152)$ & $(0.152)$ & $(0.139)$ & $(0.139)$ \\
\hline \multirow[t]{2}{*}{ 2015.year\#married } & $-0.334^{* * *}$ & $-0.334^{* * *}$ & $-0.288^{* * *}$ & $-0.288^{* * *}$ \\
\hline & $(0.0383)$ & $(0.0383)$ & $(0.0419)$ & $(0.0419)$ \\
\hline \multirow[t]{2}{*}{ 2015.year\#separated/widowed } & -0.111 & -0.111 & -0.0667 & -0.0667 \\
\hline & $(0.0951)$ & $(0.0951)$ & $(0.0844)$ & $(0.0844)$ \\
\hline years\#region & \multicolumn{2}{|c|}{ No } & \multicolumn{2}{|c|}{ Yes } \\
\hline Observations & \multicolumn{4}{|c|}{811,908} \\
\hline Wald chi2 $\left(^{*}\right)$ & \multicolumn{2}{|c|}{ (29) 8012.75} & \multicolumn{2}{|c|}{ (39) 10735.29} \\
\hline Prob > chi2 & \multicolumn{2}{|c|}{0.000} & \multicolumn{2}{|c|}{0.000} \\
\hline Pseudo R-squared & \multicolumn{2}{|c|}{0.2209} & \multicolumn{2}{|c|}{0.2229} \\
\hline
\end{tabular}

Coef $=$ coefficient, $\mathrm{OR}=$ odds ratio.

Notes: Robust standard errors in parentheses. Adjusted for clustering. ${ }^{* *}$, ** and ${ }^{*}$ indicate significance at $1 \%, 5 \%$, and $10 \%$, respectively. Wald chi2 $\left(^{*}\right)$ in parentheses per model ran. Reference categories with coefficients and odds ratios of 0 and 1 , respectively, are omitted. The reference categories for each variable are: year\#(15-24) for age group, female for sex, none to preprimary for education, agriculture for sector, rural for location, single for marital status.

Source: Authors' calculations. 


\section{REFERENCES}

Acemoglu, Darren, and Pascual Restrepo. 2017. "Demographics and Robots: Theory and Evidence." Work in progress.

2018. "Artificial Intelligence, Automation and Work.” Work in progress. Agresti, Alan. 2013. Categorical Data Analysis. Hoboken, NJ: Wiley.

Allison, Paul D. 1999. "Comparing Logit and Probit Coefficients across Groups.” Sociological Methods \& Research 28 (2): 186-208.

—. 2012. "Logistic Regression for Rare Events." https://statisticalhorizons.com/logisticregression-for-rare-events.

Anukriti, S., Sonia Bhalotra, and Hiu Tam. 2016. "On the Quantity and Quality of Girls: New Evidence on Abortion, Fertility, and Parental Investments." IZA Discussion Papers 10271. Institute of Labor Economics (IZA).

Asian Development Bank (ADB). 2018. Asian Development Outlook: How Technology Affects Jobs. Manila.

Aubert, Patrick, Eve Caroli, and Muriel Roger. 2006. "New Technologies, Organisation and Age: FirmLevel Evidence.” The Economic Journal 116 (509): 73-93.

Autor, David H. 2014. "Polanyi's Paradox and the Shape of Employment Growth." Draft prepared for the Federal Reserve Bank of Kansas City.

Autor, David H., Lawrence F. Katz, and Alan B. Krueger. 1997. “Computing Inequality: Have Computers Changed the Labor Market?” NBER Working Paper No. 5956.

Beckmann, Michael, and Bernd Schauenberg. 2007. "Age-Biased Technological and Organizational Change: Firm-Level Evidence and Management Implications." Working Papers 2007/05. Faculty of Business and Economics - University of Basel.

Borghans, Lex, and Bas ter Weel. 2002. "Do Older Workers Have More Trouble Using a Computer Than Younger Workers?" ROA Research Memorandum 003. Maastricht University, Research Centre for Education and the Labour Market (ROA).

Buis, Maarten. 2017. "Logistic Regression: When Can We Do What We Think We Can Do?" http://www.maartenbuis.nl/wp/odds_ratio_3.1.pdf.

Chang, Jae-Hee, Gary Rynhart, and Phu Huynh. 2016. "ASEAN in Transformation: How Technology is Changing Jobs and Enterprises.” Bureau for Employers' Activities Working Paper No. 10. International Labour Organization (ILO).

Chun, Natalie, and Heiwai Tang. 2018. "Do Information and Communication Technologies Empower Female Workers? Firm-Level Evidence from Viet Nam.” ADB Economics Working Paper Series No. 545. 
Dasgupta, Sukti, and Sher Singh Verick. 2016. Transformation of Women at Work in Asia: An Unfinished Development Agenda. ILO, Geneva: Sage.

Eberharter, Veronika V. 2012. "The Intergenerational Transmission of Occupational Preferences, Segregation, and Wage Inequality: Empirical Evidence from Three Countries." SOEP papers on Multidisciplinary Panel Data Research No. 506. Berlin: Deutsches Institut für Wirtschaftsforschung (DIW).

Firth, David. 1993. “Bias Reduction of Maximum Likelihood Estimates.” Biometrika 80 (1): 27-38.

Fitzmaurice, Garrett. M., Nan M. Laird, and James H. Ware. 2004. Applied Longitudinal Analysis. Hoboken, NJ: Wiley.

Frey, Carl B., and Ebrahim Rahbari. 2016. "Do Labor-Saving Technologies Spell the Death of Jobs in the Developing World.” Paper prepared for the 2016 Brookings Blum Roundtable.

General Statistics Office (GSO). 2009. Labor Force Survey. Government of Viet Nam.

2013. Labor Force Survey. Government of Viet Nam.

2015. Labor Force Survey. Government of Viet Nam.

Goos, Maarten, and Alan Manning. 2007. "Lousy and Lovely Jobs: The Rising Polarization of Work in Britain." The Review of Economics and Statistics 89 (1): 118-33.

Gupta, Nabanita D., and Amaresh Dubey. 2006. "Fertility and the Household's Economic Status: A Natural Experiment Using Indian Micro Data." Journal of Development Studies 42 (1): 110-38.

International Labour Organization (ILO). 1993. The Revised International Standard Classification of Occupations. http://www.ilo.org/public/english/bureau/stat/download/papers/short.pdf.

2012. International Standard Classification of Occupations. ISCO-08 Volume I. http://www.ilo.org/wcmsp5/groups/public/---dgreports/---dcomm/--publ/documents/publication/wcms_172572.pdf.

Jacobs, Jane. 1969. Economy of Cities. New York: Random House.

Jayaraman Anuja, Vinod Mishra, and Fred Arnold. 2009. "The Relationship of Family Size and Composition to Fertility Desires, Contraceptive Adoption and Method Choice in South Asia." International Perspectives on Sexual and Reproductive Health 35 (1): 29-38.

Jaynes, Edwin T. 2003. Probability Theory: The Logic of Science. Cambridge, UK: Cambridge University Press.

Karlson, Kristian B. 2015. "Another Look at the Method of y-standardization in Logit and Probit Models. The Journal of Mathematical Sociology 39 (1): 29-38.

Keynes, John M. 1921 (2004). A Treatise on Probability. Mineola, NY: Dover Publications, Inc. 
Kiyota, Kozo, and Sawako Maruyama. 2018. :On the Demand for Female Workers in Japan: The Role of ICT and Offshoring." Asian Economic Papers 17 (2): 25-46. https://www.mitpressjournals.org/ doi/pdf/10.1162/asep_a_00604.

Kuha, Johni, and Colin Mills. 2017. "On Group Comparisons With Logistic Regression Models. Sociological Methods \& Research.” https://doi.org/10.1177/0049124117747306.

Lee, Jong-Wha, and Dainn Wie. 2013. "Technological Change, Skill Demand, and Wage Inequality in Indonesia." ADB Economics Working Paper Series No. 340. Manila: ADB.

Leitgöb, Heinz. 2013. "The Problem of Rare Events in Maximum Likelihood Logistic RegressionAssessing Potential Remedies.” Working paper. https://www.europeansurveyresearch.org/ conf/uploads/494/678/167/PresentationLeitg_b.pdf.Lin, Jeffrey. 2011. "Technological Adaptation, Cities, and New Work." The Review of Economics and Statistics 93 (2): 554-74.

Long, J. Scott. 1997. Regression Models for Categorical and Limited Dependent Variables. Advanced Quantitative Techniques in the Social Sciences. Thousand Oaks, CA: Sage.

2009. “Group Comparisons in Logit and Probit Using Predicted Probabilities.” Working paper. http://www.indiana.edu/ jslsoc/files_research/groupdif/groupwithprobabilities/groups-withprob-2009-06-25.pdf.

Long, J. Scott, and Jeremy Freese. 2006. Regression Models for Categorical Dependent Variables Using Stata. 2nd ed. College Station, TX: Stata Press.

Louviere, Jordan J., David A. Hensher, and Joffre D. Swait. 2000. Stated Choice Methods. Analysis and Applications. Cambridge, MA: Cambridge University Press.

Manpower Group. 2018. 2018 Talent Shortage Survey. https://go.manpowergroup.com/hubfs/ TalentShortage\%202018\%20(Global)\%20Assets/PDFs/MG_TalentShortage2018_lo\%206_2 5_18_FINAL.pdf?t=1539897144662.

McFadden, Daniel. 1974. "Conditional Logit Analysis of Qualitative Choice Behavior.” In Frontiers in Econometrics, edited by P. Zarembka, 105-42. New York: Wiley.

McKinsey Global Institute. 2017. Jobs Lost, Jobs Gained: Workforce Transitions in a Time of Automation. McKinsey \& Company.

Mood, Carina. 2010. "Logistic Regression: Why We Cannot Do What We Think We Can Do, and What We Can Do About It." European Sociological Review 26 (1): 67-82.

Murciano-Goroff, Raviv. 2018. "Missing Women in Tech: The Labor Market for Highly Skilled Software Engineers." Work in progress. http://stanford.edu/ ravivmg/papers/JMP.pdf.

National Sample Survey Office (NSSO). 2014. Employment and Unemployment Situation in India. NSS 68th Round. Government of India. 
National Sample Survey Organisation (NSSO). 1996. Key Results on Employment and Unemployment. NSS 50th Round. Government of India.

2000. Employment and Unemployment in India 1999-2000: Key Results. NSS 55th Round. Government of India.

Olson, Katherine E., Marita A. O'Brien, Wendy A. Rogers, and Neil Charness. 2011. "Diffusion of Technology: Frequency of Use for Younger and Older Adults." Ageing International 36 (1): 12345.

Payscale. 2018. Spot Check: How do Top Tech Employers Compare? https://www.payscale.com/datapackages/top-tech-companies-compared.

Peng, Fei, Sajid Anwar, and Lili Kang. 2017. "New Technology and Old Institutions: An Empirical Analysis of the Skill-Biased Demand for Older Workers in Europe." Economic Modelling 64 (C): $1-19$.

Polachek, Solomon W., and William Siebert S. 1993. The Economics of Earnings. Cambridge, UK: Cambridge University Press.

Quartz. 2017. "Tech is Overwhelmingly White and Male, and White Men Are Just Fine With That." https://qz.com/940660/tech-is-overwhelmingly-male-and-men-are-just-fine-with-that/.

Schleife, Katrin. 2008. "IT Training and Employability of Older Workers." ZEW Discussion Papers 08021. ZEW - Zentrum für Europäische Wirtschaftsforschung. Center for European Economic Research.

Schmidt, Peter, and Robert Strauss. 1975. "The Prediction of Occupation Using Multiple Logit Models." International Economic Review 16 (2): 471-85.

Söderbom, Måns. 2009. Applied Econometrics Lecture 10: Binary Choice Models. Retrieved from http://www.soderbom.net/lecture10notes.pdf.

United Nations Conference on Trade and Development (UNCTAD). 2018. Technology and Innovation Report. https://unctad.org/en/PublicationsLibrary/tir2018_en.pdf.

U.S. Bureau of Labor Statistics. 2016. The high-tech industry, what is it and why it matters to our economic future. Vol. 5 No. 8. https://www.bls.gov/opub/btn/volume-5/pdf/the-high-tech-industrywhat-is-it-and-why-it-matters-to-our-economic-future.pdf.

—. Employment Projections. https://www.bls.gov/emp/tables/median-age-labor-force.htm.

U.S. Census Bureau. 1950. Alphabetical Index of Occupations and Industries: 1950. Washington, DC.

Wang, Wendy. 2005. Son Preference and Educational Opportunities of Children in China-"I Wish You Were a Boy!" Gender Issues 22 (3): 3-30.

Williams, Richards. 2009. "Using Heterogeneous Choice Models to Compare Logit and Probit Coefficients Across Groups.” Sociological Methods \& Research 37 (4): 531-59. 
_ 2018. Analyzing Rare Events with Logistic Regression. https://www3.nd.edu/ rwilliam/stats3/ rareevents.pdf.

Winship, Christopher, and Robert D. Mare. 1984. "Regression Models with Ordinal Variables. American Sociological Review 49 (4): 512-25.

World Bank. 2017. World Development Indicators. Washington, DC. 


\section{New Technology and Emerging Occupations: Evidence from Asia}

This paper explores how technology affects labor market outcomes in Asia through the creation of new types of work. It investigates how workers' characteristics can influence one's chances of accessing emerging occupations-defined as occupation groups with new job titles. Comparisons of successive lists of the National Classification of Occupations in India, Malaysia, the Philippines, and Viet Nam find that most new job titles are for highly-skilled positions that involve data and information and communication technology. Adjusted predictions by education and sector show that access to emerging occupations are highest among tertiary-educated workers in services. Chances of success can vary greatly across age groups.

\section{About the Asian Development Bank}

ADB is committed to achieving a prosperous, inclusive, resilient, and sustainable Asia and the Pacific, while sustaining its efforts to eradicate extreme poverty. Established in 1966, it is owned by 68 members49 from the region. Its main instruments for helping its developing member countries are policy dialogue, loans, equity investments, guarantees, grants, and technical assistance. 